\title{
Weighty Thoughts; a cognitive approach to the treatment of obesity
}

Citation for published version (APA):

Werrij, M. Q. (2005). Weighty Thoughts; a cognitive approach to the treatment of obesity. [Doctoral Thesis, Maastricht University]. Ponsen \& Looijen BV. https://doi.org/10.26481/dis.20051124mw

Document status and date:

Published: 01/01/2005

DOI:

10.26481/dis.20051124mw

Document Version:

Publisher's PDF, also known as Version of record

\section{Please check the document version of this publication:}

- A submitted manuscript is the version of the article upon submission and before peer-review. There can be important differences between the submitted version and the official published version of record.

People interested in the research are advised to contact the author for the final version of the publication, or visit the DOI to the publisher's website.

- The final author version and the galley proof are versions of the publication after peer review.

- The final published version features the final layout of the paper including the volume, issue and page numbers.

Link to publication

\footnotetext{
General rights rights.

- You may freely distribute the URL identifying the publication in the public portal. please follow below link for the End User Agreement:

www.umlib.nl/taverne-license

Take down policy

If you believe that this document breaches copyright please contact us at:

repository@maastrichtuniversity.nl

providing details and we will investigate your claim.
}

Copyright and moral rights for the publications made accessible in the public portal are retained by the authors and/or other copyright owners and it is a condition of accessing publications that users recognise and abide by the legal requirements associated with these

- Users may download and print one copy of any publication from the public portal for the purpose of private study or research.

- You may not further distribute the material or use it for any profit-making activity or commercial gain

If the publication is distributed under the terms of Article $25 \mathrm{fa}$ of the Dutch Copyright Act, indicated by the "Taverne" license above, 

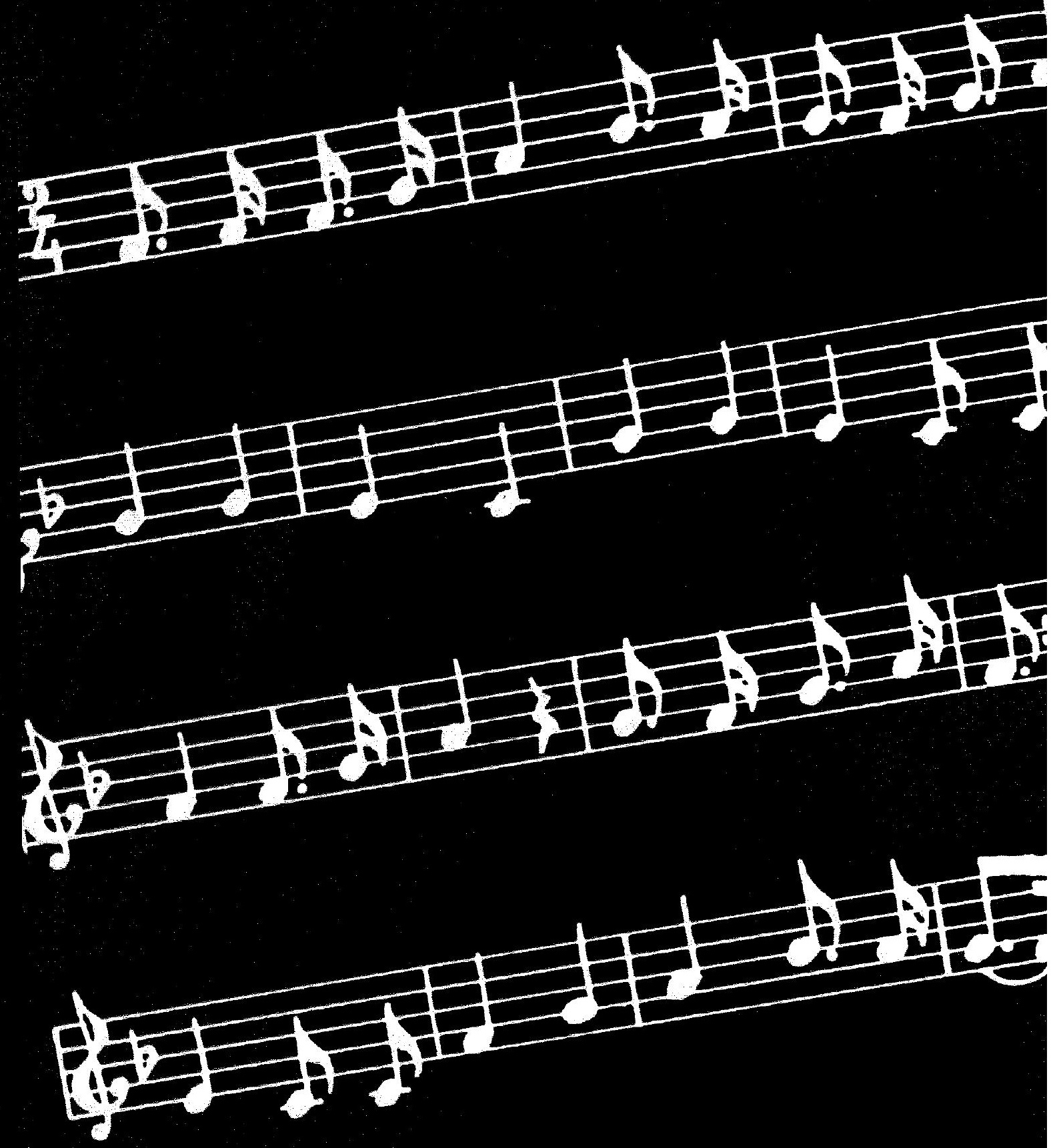


\section{WEIGHTY THOUGHTS A COGNITIVE APPROACH TO THE TREATMENT OF OBESITY}




\title{
WEIGHTY THOUGHTS A COGNITIVE APPROACH TO THE TREATMENT OF OBESITY
}

\author{
Proefschrift
}

ter verkrijging van de graad van doctor aan de Universiteit Maastricht, op gezag van de Rector Magnificus, Prof. Mr. G.P.M.F. Mols, volgens het besluit van het College van Decanen, in het openbaar te verdedigen op donderdag 24 november 2005 om 12.00 uur

door

Marieke Quirine Werrij 


\section{Promotores}

Prof. Dr. A.T.M. Jansen

Prof. Dr. H.J. Hospers

\section{Copromotor}

Dr. A.A.N. Mulkens

\section{Beoordelingscommissie}

Prof. Dr. G.J. Kok (voorzitter)

Dr. S.M. Bögels

Prof. Dr. Ir. J. Brug (Erasmus MC)

Dr. M.L. Peters

Prof. Dr. Ir. I.C. Seidell (Vrije Universiteit Amsterdam]

\section{Colophon}

Cover design by Fenne Roefs

Layout by John Derwall, Eric Lemmens, Iris van Hezik, D\&L graphics, www.dlgraphics.nl, proefschrift@dlgraphics.nl

Production: Ponsen \& Looijen BV, Wageningen

(C) Marieke Werrij, Maastricht 2005

ISBN-10: 9085900069

ISBN-13: 9789085900061

The studies presented in this dissertation were conducted under the auspices of the Care and Public Health Research Institute (Caphri) at Maastricht University. Caphri is part of the Netherlands School of Primary Care Research (CaRe) which has been acknowledged since 1995 by the Royal Netherlands Academy of Arts and Sciences (KNAW).

The studies were funded by The Netherlands Organisation for Health Research and Development (ZonMw). 


\section{Contents}

Dankwoord

Chapter 1 General introduction and thesis outline

Chapter 2 Dietary treatment for obesity reduces BMI

and improves eating psychopathology, self-esteem and mood

Chapter 3 Overweight and obesity: the significance of a depressed mood

Chapter 4 The cognitive model and treatment

Chapter 5 CBT prevents relapse in obesity treatment whereas standard behavior therapy does not: results from a RCT

Chapter 6 Early associations with palatable foods in obesity are not disinhibition related but restraint related

Chapter 7 General discussion

Summary

Samenvatting

References

Publications 


\section{DANKWOORD}


Lang heb ik uitgekeken naar dit moment. Het schrijven van een dankwoord leek me leuk, omdat je eindelijk die mensen in het zonnetje kunt zetten die - allen op hun eigen manier hebben geholpen om tot dit eindresultaat te komen: een proefschrift! Maar natuurlijk is het schrijven van een dankwoord ook moeilijk omdat je de juiste woorden moet vinden voor ledereen, en omdat je het risico loopt om mensen te vergeten. Voor dit laatste vast mijn excuses, iedereen die ik nu vergeet: bedankt!

Allereerst wil ik mijn driekoppige begeleidingsteam bedanken. Anita, jij werd pas in een later stadium mijn promotor. Toch mocht ik al veel eerder profiteren van jouw deskundigheid en inhoudelijk enthousiasme doordat je me meteen "adopteerde" in de eetclub. Na een afspraak met jou had ik altijd het gevoel dat ik weer met sprongen vooruit kon; er werden knopen doorgehakt en ik werd aangestoken door jouw enthousiasme. Dank je wel dat je mijn promotor werd en dat ik zo veel van je mocht leren. Harm, jij was vooral in de eerste periode op de voorgrond. Ik herinner mij nog goed hoe jij met één telefoontje soms dingen geregeld kreeg die mij veel meer moeite kostten. Bedankt voor jouw daadkracht en doortastend optreden als dat nodig was. Sandra, bij jou kon ik altijd terecht, al vanaf het begin. Wat zou de training "Dik Tevreden" zijn geweest zonder jouw expertise als therapeut. Later werd je officieel copromotor en dacht je graag met me mee over analyses, artikelen en nog veel meer. Dank je wel voor al je hulp en voor de fijne samenwerking.

Toen ik begon aan dit project had ik weinig verstand van cognitieve therapie, en ik las me zo goed mogelijk in om de principes van deze therapievorm te begrijpen. Uiteindelijk zou de training "Dik Tevreden" echter nooit zijn geworden wat ie is zonder de hulp van een ervaren cognitief therapeut. Hermien, ontzettend bedankt voor je inzet, deskundigheid en creativiteit bij het ontwikkelen van de training, en voor het trainen en superviseren van de vele therapeuten die deelnamen aan het onderzoek. Samenwerken met jou was leerzaam en erg leuk.

Dames van het Groene Kruis en met name Yvonne, Nelly, Sonja, Petra, Karin en Carla. Voor jullie was het niet altijd even eenvoudig om rekening te houden met de wensen van een wetenschapper. Toch ging de samenwerking soepel en hebben wij het samen voor elkaar gekregen om een gerandomiseerd onderzoek te draaien met 200 deelnemers. Dat is geen slechte prestatie, en zonder jullie steun had ik dat nooit gered. Heel veel dank daarvoor. Ook de fysiotherapeuten die betrokken waren bij het onderzoek, Frans Philippens en Jack van Loo, wil ik bedanken voor de prettige samenwerking. En dan natuurlijk de vele cognitief therapeuten die de groepen uit de "versie met psycholoog" voor hun rekening namen: Stephanie, Harmanne, Martha, Sandra, Anoek, Karin, Heidi, Annemiek, Aafke, en Sanne. Ook zonder jullie zou ik niet ver gekomen zijn. Heel veel dank voor jullie inzet. En dan tenslotte, wat is een onderzoek zonder "proefpersonen". Alle mensen met overgewicht die hebben meegedaan aan de studies wil ik bij dezen nog eens hartelijk bedanken.

Eetclub: Anita, Sjaan, Remco, Anne, Sandra, Esther, Ramona en Elke, wat was het een plezier om met jullie te mogen samenwerken. Ik heb de vele eetclub-bijeenkomsten, maar vooral ook de onderzoeksmiddagen met bijbehorende, jawel, etentjes enorm gewaardeerd. 
Behalve nuttig waren deze ook vaak erg gezellig: dank jullie wel, ik zal jullie missen. André en Marloes (E), bedankt voor jullie hulp bij de kosten-effectiviteitsanalyse. Gerard en Herbert, bedankt woor de ad-hoc adviezen op statistisch gebied. Rob en Hein, wat fijn dat wij samen zo'm mooi onderzoeksvoorstel schreven, veel dank voor jullie inzet. Nicole $(\mathrm{N}$ ), Truus, en Jessie, bedankt voor het regelen van zoveel praktische zaken. Collega's van EP, bedankt voor alle gezelligheid. Nora Oosting en Jaap Elgersma, bedankt voor het op passende wijze vormgeven en illustreren van het "Dik Tevreden" werkboekje. Fenne, dank je wel voor het maken van de prachtige voorkant en John \& Eric, bedankt voor het verzorgen van de mooie layout van mijn proefschrift.

Een groot onderzoek betekent ook: veel data. En die data moeten ingevoerd worden. Daarnaast betekent een veldstudie veel praktisch en organisatorisch werk, dat soms niet door mij alleen gedaan kon worden. Denk bijvoorbeeld aan de follow-up bijeenkomsten waar ik altijd een maatje nodig had om de deelnemers te wegen en te meten. Aan vele student(assistent)en ben ik dank verschuldigd: Laura, Dirk, Nina, Cora, Anouk, Janneke, Susanne, Bilbo, en Barbara, heel erg bedankt voor jullie onmisbare hulp. Ook de twee priming studies had ik niet kumnen doen zonder de hulp van Inge en Daphne bij het verzamelen van de data. Bedankt dat jullie al die mensen hebben getest.

Anne, wat een geluk heb ik met jou als kamergenoot. In de afgelopen jaren werd jij voor mij een waardevolle vriendin. Jij stond werkelijk altijd klaar om mij te helpen met problemen van welke aard dan ook: inhoudelijke vragen discussieerden we uit en ook praktische problemen hielp jij mij oplossen. Weet je nog, samen gewapend met weegschaal in de kofferbak van jullie auto op weg naar tegensputterende proefpersonen... Anne, dank je wel voor je onvoorwaardelijke steun, voor de heerlijke etentjes en natuurlijk ook voor alle gezelligheid. Ik ben blij dat wij nog lang samen een kamer zullen delen. Nicole $(K)$, wat fijn dat ik mijn gedachten over praktijkonderzoek met jou kon delen. Bedankt voor de vele koffie breaks met inhoud. Martien en Ellen, bedankt woor de nodige kleine ontspanning tussendoor in de worm van heerlijk ontbijten en wandelingetjes om het gebouw.

Marloes $(M)$ en Monique, al wanaf het begin stond vast dat jullie mijn paranimfen zouden worden. Wat hebben wij veel gepraat en gelachen over onze projecten, die precies tegelijk van start gingen. Wij hebben samen al heel wat meegemaakt, met als hoogtepunt denk ik wel ons hilarische reisje naar Venetië. Ik ben blij en trots met zulke paranimfen. Lieve Bar en Bil, dank jullie wel voor jullie steun en praktische hulp in de afgelopen jaren. Lieve papa en mama, jullie hebben altijd enorm meegeleefd en meegedacht. Bedankt voor jullie vertrouwen en voor jullie nooit aflatende steun. Lieve Robert, als ik moet opsommen waarvoor ik jou wil bedanken, ben ik wel even bezig. Misschien bedank ik je gewoon voor die keren dat jij met je heerlije maaltijden (onder de snelbinders van de fiets) naar de uns $40 \mathrm{kwam}$ als de mensa weer eens dicht was, voor het vele wachten, voor je relativerende opmerkingen en voor je oneindige steun. Ik zal het maar zo zeggen, met jou ben ik meer dan Dik Tevreden! 


\section{CHAPTER 1}

GENERAL INTRODUCTION AND

THESIS OUTLINE 
Chapter I 
Have you ever tried to diet? Tried to lose weight because you were too fat? And, did you succeed? Many kinds of diets are available nowadays, and they all seem attractive for producing weight loss quickly. Some of them even allow you to eat as much as you want. The Atkins diet for example, allows you to eat as much fat as you like; you just should not eat carbohydrates. The Ormish diet, in contrast, is directed to the opposite: the restriction of fat intake. Weight Watchers, a third popular dieting method, aims to restrict calorie intake in general. Although all these diets claim to work through their own specific metabolic effects, the average effects of these diets on weight loss are the same. In the short term, they all produce modest weight loss in those people who adhere to the diet (Dansinger, Gleason, Griffith, Selker, Schaefer, 2005); not the particular diet but adherence to it appeared to be the crucial factor for the diet to be effective. This adherence, however, is precisely what is so difficult. Imagine that you have to stick to a diet while your friends are enjoying a nice dinner. Wouldn't it be tempting to - at least temporarily - break your diet?

Dieting is daily life reality for millions of obese people. How can obese people be helped to lose weight and, more importantly, to maintain the weight loss they reach? The present dissertation concerns exactly this question. In this chapter, an overview of the definition, the prevalence and the health risks of obesity is given. Next, a brief description of surgical, pharmacological and behavioral treatments for obesity and their effectiveness is provided, followed by the introduction of a cognitive approach for treating obesity. Finally, the chapter ends with an outline of this thesis.

\section{Prevalence and health consequences of obesity}

Obesity is a growing public health problem. In recent years, the prevalence of obesity has grown so much, that the World Health Organization even declared obesity a global epidemic (WHO, 2000). Classifications of overweight and obesity are usually based on the Body Mass Index (BMI), which is calculated as weight in kilograms divided by height in meters squared (Bray, $1998 ; \mathrm{WHO}, 2000)$. According to the WHO (2000), the cutoff point for overweight is at a BMI of 25.0. A BMI between 18.5 and 24.9 is defined as normal weight, a BMI between 25.0 and 29.9 as pre-obese, and a BMI above 30 as obese. In a Dutch sample of people aged 37.43 years, the prevalence of obesity increased from $6.2 \%(n=8922)$ to $9.3 \%(n=2518)$ in women, and from $4.9 \%(n=8086)$ to $8.5 \%(n=2105)$ in men between 1976 and 1997 . The prevalence of pre-obesity remained the same in these 20 years: $24.6-25.0 \%$ in women, and $38.3-40.2 \%$ in men (Visscher, Kromhout, \& Seidell, 2002). In Dutch $20-59$ year old people, followed between 1993 and 1997, the prevalence of obesity increased with age and was more then three times higher in people with a low educational level than in people with a high educational level (see Table 1.1) (Visscher et al., 2002). Recent data show that in $2003,10.7 \%$ of the Dutch population was obese, and another $35.4 \%$ was pre-obese (CBS, 2005). This means that in total, $46.1 \%$ of the Dutch population was overweight. In the United States, these percentages are 
even more alarming. There, about $21 \%$ (Mokdad et al., 2003) to 30\% (Hedley et al., 2004) of the population is obese and 35\% (Hedley et al., 2004) to 37\% (Mokdad et al., 2003) is pre-obese. So in total, $58 \%$ to $65 \%$ of the Americans are overweight. The current environment, characterized by the unlimited availability of high fat, highly palatable foods on the one hand, and the discouragement of physical activity (i.e., for an average person, only low levels of physical activity are needed in daily life) on the other hand, may be held responsible for these epidemic proportions of obesity (e.g., Hill \& Peters, 1998; Wadden, Brownell, \& Foster, 2002].

Table 1.1: Mean prevalence of obesity in the Netherlands by age and highest educational level reached 1 period 1903 . $1907)$.

\begin{tabular}{|c|c|c|c|c|c|}
\hline & Wamen & & & Men & \\
\hline Age & $n$ & Prevalence & Age & $n$ & Prevalence \\
\hline 2029 & 2191 & 54 & $20-29$ & 1581 & 4.4 \\
\hline 3039 & 2826 & 74 & 30.39 & 2374 & 67 \\
\hline $40-49$ & 3695 & 111 & $40-49$ & 3083 & 10.5 \\
\hline 5059 & 3233 & 170 & $50-59$ & 2943 & 14.7 \\
\hline Educational level & $n$ & Prevalence & Educational level & $n$ & Prevalence \\
\hline Primary school & 1446 & 178 & Primary school & 1089 & 154 \\
\hline $\begin{array}{l}\text { Junior (vocational) } \\
\text { school }\end{array}$ & 2758 & 137 & Junior (wocational) scheol & 2249 & 114 \\
\hline $\begin{array}{l}\text { Secondary (vocational) } \\
\text { school }\end{array}$ & 1998 & 101 & $\begin{array}{l}\text { Seconday (vocational) } \\
\text { school }\end{array}$ & 986 & 99 \\
\hline Vocational colleges & 3103 & 71 & Vocational colleges & 2939 & 71 \\
\hline University & 2539 & 3,4 & University & 2655 & 4.7 \\
\hline
\end{tabular}

Obesity is associated with several health problems, including cardiovascular diseases, type II diabetes, some forms of cancer, muscoskeletal disorders (osteoarthritis) respiratory disorders (shortness of breath, sleep apnea) and work disability (Visscher \& Seidell, 2001; WHO, 1998). On the psychological level - although evidence is not entirely unequivocal - obesity has been associated with a variety of problems, such as binge eating, concerns about appearance, depressed mood and low self-esteem [e.g., Berman, Berman, Heymsfield, Fauci, \& Ackerman, 1992; Johnson, Gorin, Stone, \& LeGrange, 2003; Musante, Costanzo, \& Friedman, 1998; Quinn \& Crocker, 1999; Stunkard \& Wadden, 1992; Wilfley, Schwartz, Spurrell, \& Fairburn, 2000). According to the Diagnostic and Statistical Manual of Mental Disorders (DSM-TV; APA, 1994), binge eating refers to the consumption of a large amount of food coupled with a loss of control over eating, and followed by emotional distress. When eating binges occur at least twice a week during a six months period, binge eating disorder (BED) is diagnosed (DSM-IV; APA, 1994). 
The prevalence of BED varies from $8 \%$ in a general population of overweight people (Bruce \& Agras, 1992) to as much as $20-50 \%$ in a population of obese people seeking weight loss treatment (de Zwaan \& Mitchell, 1992; Johnson et al., 2003; Spitżer et al., 1992).

Studies investigating eating disorder related psychopathology [i.e., overconcerns about shape, weight and eating in obese people found concerns about shape and weight to be higher than in normal weight controls (Fairburn \& Cooper, 1993; Wilfley et al., 2000). Obese binge eaters were even as concerned about their shape and weight as bulimia nervosa patients (Marcus, Smith, Santelli, \& Kaye, 1992; Masheb \& Grilo, 2000; Sullivan, 2001; Wilfiey et al., 2000). Concerns about eating did not differ between obese people in general and people of normal weight (Fairburn \& Cooper, 1993; Wilfley et al., 2000), but obese binge eaters scored higher on this measure than normal weight controls (Marcus et al., 1992; Sullivan, 2001; Wiffley et al., 2000]. Findings on depressive symptoms in obese people are mixed. Some studies found obese participants to be moderately depressed (Kalarchian, Wilson, Brolin, \& Bradley, 1998; Musante et al., 1998; Polivy \& Herman, 1992; Porzelius, Houston, Smith, Arfken, \& Fisher, 1995; Tanco, Linden, \& Earle, 1998; Telch \& Agras, 1994; Troisi et al., 2001), whereas in other studies non-clinical levels of depression were observed (Porzelius et al., 1995; Sbrocco, Nedegaard, Stone, \& Lewis, 1999; Venditti, Wing, Jakicic, Butler, \& Marcus, 1996). Levels of depression were generally higher when binge eating severity increased (e.g., Isnard et al., 2003; Johnson et al., 2003; Telch \& Agras, 1994; Venditti et al., 1996). Self-esteem of obese binge eaters was found to be lower than that of obese non-binge eaters (de Zwaan et al., 1994; Striegel-Moore, Wilson, Wilfley, Elder, \& Brownell, 1998). However, also in a general sample of overweight people self-esteem appeared to be lower than in peers of normal weight (Quinn \& Crocker, 1999). Notably, most of the studies reviewed above show that obese binge eaters have higher levels of eating psychopathology and depression, and lower self-esteem than obese non-bingers. Consistently, previous research suggests that it is not BMI that accounts for psychopathology in obese people, but rather mediating factors such as binge eating le.g., de Zwaan et al., 1994; Isnard et al., 2003; Johnsen et al., 2003; Picot \& Lilenfeld, 2003; Telch \& Agras, 1994; Venditti et al., 1996). The causal relationship between binge eating, psychopathology and BMI, however, has not been established yet; most data is correlational in nature. To reduce these health risks associated with obesity, obese people are mostly recommended to lose weight.

\section{HOW TO TREAT OBESITY?}

Although it is recognized that genes make people vulnerable for obesity, it is generally agreed that is the environment that finally determines whether obesity is expressed (e.g., Barsh, Farooqi \& O'Rahilly, 2000; Hill \& Peters, 1998; Wadden et al., 2002). Uitimately, it is simply an energy imbalance - energy intake being greater than energy expenditure - that causes weight gain. Genetic predisposition in itself is not changeable, whereas energy intake and 
energy expenditure are. Logically, (behavioral) treatments for obesity are therefore directed at changing those behaviors (Wadden, Sarwer, \& Berkowitz, 1999), although most treatments focus particularly on eating behavior, and put less effort in increasing physical activity. In general, there are three major types of obesity treatments: surgical treatment, pharmacological treatment and behavioral treatment.

Surgical treatment. By surgically limiting the stomach's capacity for food, bariatric surgery is highly effective in producing weight loss (Brolin, Robertson, Kenler, \& Cody, 1994; Kral, 1992; Sjostrom et al., 2004). A recently published trial showed $23 \%$ weight loss two years after surgery and $16 \%$ weight loss after ten years (Sjostrom et al., 2004). Furthermore, surgery improved lifestyle (1.e., reduced energy intake and increased physical activity), and ameliorated health risks associated with obesity such as diabetes and hypertension (e.g., Sjostrom et al., 2004). However, although levels of complications are now believed to be acceptable, serious complications occur in about $2 \%$ of patients and less serious ones in up to $30 \%$ (for a review see Hsu et al., 1998). Furthermore, it is important to note that the benefits of bariatric surgery do not apply to all obese people who underwent an operation. About $30 \%$ of the surgery patients regain weight at $18-24$ months after the operation. There thus is a great individual variability in the effectiveness of bariatric surgery (Hsu et al., 1998). As Hsu and colleagues suggested, eating behavior may be one of the factors leading to poor outcome of surgery (Hsu et al., 1998) as some people gradually learn to overcome the radically limited food intake that is forced by the surgery, and start eating large quantities of soft foods or liquids by increasing the frequency of intake (Brolin et al., 1994; Kral, Gortz, Henmansson, \& Wallin, 1993). A major drawback of bariatric surgery is that - also if the surgery is successful - the patient is prevented from having a normal, healthy diet because of the drastically limited stomach capacity. Obviously, adherence to this low-calorie postoperative diet is a struggle for many patients (Sarwer, Wadden, \& Fabricatore, 2005). Only severely obese people (BMI > 40), or less severely obese people (BMI > 35) with high-risk comorbidities, are eligible for bariatric surgery.

Pharmacological treatment. Three groups of drugs can be distinguished that operate through different mechanisms; drugs that reduce food intake (e.g., phentermine), drugs that alter metabolism (e.g, orlistat) and drugs that increase thermogenesis (e.g., ephedrine). In general, these medicines produce modest weight losses of nearly $10 \%$ as long as the medication is continued 1 Bray, 2000). The arrival of orlistat, reducing the digestion of dietary fat, raised expectations for abesity treatment. When used in combination with dietary restriction, orlistat has been demonstrated to be effective in producing weight loss as well as in achieving weight maintenance (for a review see Cahill \& Lean, 1999). However, orlistat is ineffective in some patients and it has unpleasant side effects including increased defecation, oily feces, fecal urgency or leakage, and a decreased uptake of fat-soluble vitamins (Bray, 2000; Cahill \& Lean, 1999).

Behavioral treatment. For decades behavioral treatment, directed at decreasing dietary intake and increasing physical exercise, has been the standard treatment for obesity (Wilson, 
1994). Although the content of behavioral programs varies widely; components of these treatments nowadays often include dietary changes (no prescribed diet), goal setting, selfmonitoring, controlling the environment, managing high-risk situations, relapse prevention, and physical activity (e.g., Robinson, 2000; Wadden et al., 1999). In the short term, traditional behavioral programs on average produce weight losses of about $9 \%$ of the initial body weight (Wadden et al., 1999). With this percentage of initial body weight reduction, behavior treatments fall within the range of $5.15 \%$ weight loss, recommended by expert panels to reduce obesity-related health risks (Institute of Medicine, 1995; NIH/NHLBI, 1998; U.S. Department of Agriculture, 1995). In the short term, behavioral treatments thus result in obtaining a healthier weight. Long-term results of these programs, however, are absolutely disappointing. Within one to five years, almost all participants return to their baseline weight le.g, Garner \& Wooley, 1991; Wilson, 1994).

Strategies for producing weight loss vary widely between behavioral programs, and sometimes these programs are combined with (prescribed) very low calorie diets VLCD: $400-800 \mathrm{kcal} /$ day), low calorie diets (LCD: 800-1200 kcal/day) or popular diets (e.g., Dansinger et al., 2005; Saris, 2001). Randomized trials showed that VLCDs and LCDs initially produce rapid weight losses. The amount of weight loss does not differ between these types of diets, but compliance is higher and side effects are lower with a LCD. However, the long term effects of these diets - again are disappointing as most people regain their lost weight. The best results are obtained when the diet is combined with behavioral therapy [Saris, 2001]. Recently, the effectiveness of four popular diets (i.e., Atkins, Ornish, Weight Watchers and Zone) was examined within a randomized trial (Dansinger et al., 2005). All diets produced modest weight loss, but only in those people who adhered to the diet (Dansinger et al., 2005).

Several strategies have been proposed to improve long-term effectiveness of behavioral treatments, some of them leading to modest improvements on long-term weight loss (i.e., extending treatment length and emphasizing physical exercise) (Jeffery et al., 2000; Wadden et al., 1999/. However, maintaining weight loss remains the problematic issue. A key factor in regaining weight seems a failure to maintain the required behavioral changes in the long term (Jeffery et all., 2000).

\section{COGNITIVE TREATMENTS}

In an attempt to improve current behavioral treatments for obesity, cognitive behavioral treatments (CBT) for obesity have been proposed (Cooper \& Fairburn, 2001; Nauta, Hospers, Kok, \& Jansen, 2000]. Next to a behavioral component that addresses eating behavior, these programs consist of a cognitive component addressing cognitions. According to the founding father of cognitive therapy, Aäron Beck, dysfunctional cognitive schemes are the basis of several forms of psychopathology (Beck, 1976). These cognitive schemas are mental frameworks that organize knowledge, and are activated by incoming information (i.e., a situation). Activation 
of these dysfunctional schemes results in dysfunctional cognitions (thoughts) that eventually become automatic and uncontrollable. These dysfunctional cognitions, in turn, lead to emotions and dysfunctional behavior. Schematically, cognitive theory can be represented as follows «see Figure 1.1):

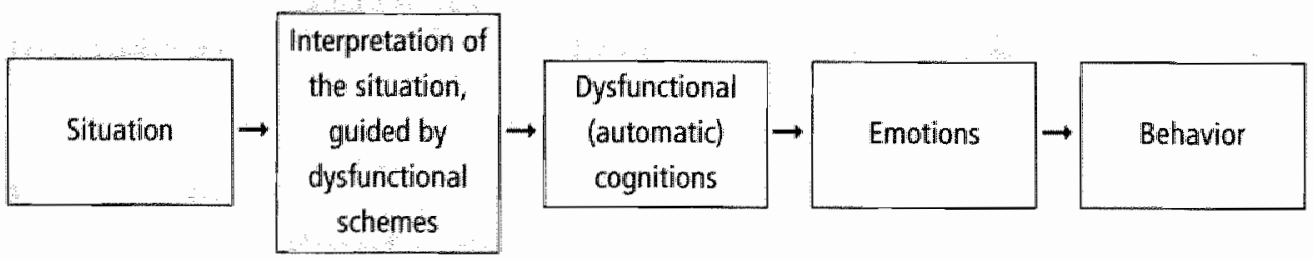

Figure 1.1: Schematic representation of cognitive theory

Cognitive therapy is aimed at changing dysfunctional cognitions (Beck, 1976). According to Beck (1976), each psychopathological disorder is characterized by its own specific schemes and automatic cognitions. Depression, for example is characterized by negative schemes about the self, the world en the future while anxiety disorders are characterized by schemes about danger.

Dysfunctional cognitions are assumed to play a significant role in disturbed eating behavior (e.g., Cooper \& Fairburn, 1992) and obesity (e.g. Nauta, Hospers, Jansen, \& Kok, 2000) as well. Cognitive behavioral treatments were shown to be effective in the treatment of eating disorders, such as bulimia nervosa (Fairburn et al., 1991; Jansen, Elgersma, Nederkoorn, \& Smeets, 2002; Wilson, 1999; Wilson \& Smith, 1987) and binge eating disorder (Agras et al., 1994; Agras, Telch, Arnow, Eldredge, \& Marnell, 1997; Nauta, Hospers, Kok, et al., 2000; Smith, Marcus, \& Kaye, 1992). After CBT, eating binges occurred less frequently and specific eating disorder related psychopathology improved. Importantly, these effects of CBT in bulimia nervosa patients are usually well maintained (e.g., Jansen et al., 2002; Wilson, 1999).

A cognitive behavioral approach to the treatment of obesity was proposed by Cooper and Fairburn (2001). They report that obese people often expect weight loss to result in improving appearances and self-evaluation. For these goals, however, weight loss is not necessary. For changing appearance, weight is only one of the factors involved and also improvement of selfevaluation can take place without weight loss. Moreover, obese people often set unrealistic goals, for example losing 20-30\% of initial body weight (Foster, Wadden, Vogt, \& Brewer, 1997; Jeffery, Wing, \& Mayer, 1998). This may lead to demoralization and giving up the dieting attempt. Therefore, a cognitive behavioral treatment was propased, in which participants learn to accept weight losses they reach, to adopt weight stability as a goal and to use behavioral and cognitive skills required for successfull weight control (Cooper \& Fairburn, 2001). The effectiveness of a pure cognitive treatment for obesity was investigated by Nauta and colleagues (2000). Aim of this cognitive treatment was to change dysfunctional cognitions about appearance, eating and self-esteem. Their data showed that the cognitive treatment was more effective in reducing eating and appearance related concerns, binge eating and - only in the short term - in improving 
selfesteem than a behavioral treatment. For weight loss, the behavioral treatment was initially superior but after six months, both groups regained weight. These findings suggest that using cognitive techniques in the treatment of obesity might improve current treatments, especially with regard to eating psychopathology and self-esteem.

\section{MAIN HYPOTHESIS}

In sum, it can be concluded that obesity is a widespread problem with increasing prevalence. Next to physiological consequences, such as cardiovascular diseases and diabetes, obesity is also associated with psychological problems, such as binge eating, overconcerns about shape and weight, depressive symptoms and low self-esteem. Treatments fol obesity include bariatric surgery, pharmacological treatments and behavioral treatments. The long-term efficacy of surgery has been proven, but only for a selected subgroup of the obese. Moreover, the operation is not always successful, and there is a risk of complications. Weight reduction medicines produce modest weight loss, but just for the time that the medication is used. Moreover, these medicines (e.g., orlistat) work best when combined with dietary restriction. Behavioral treatment, suitable for a wide range of obese people, results in short-term weight loss. Its long-term effectiveness, however, is disappointing as most participants return to their baseline weight within one to five years. For behavioral treatments to be long-term effective, it is important that people long-term adhere to the newly learned dietary patterns. In the treatment of eating disorders (i.e., bulimia nervosa), cognitive behavioral therapy is known for its enduring effects. In the treatment of obesity, cognitive therapy in a pure form was effective in reducing eating psychopathology, but not in producing weight loss. Possibly, adding cognitive therapy to the behavioral treatment for obesity may result in maintenance of the weight loss that is reached by behavioral treatments. The main goal of the present thesis is to test whether adding cognitive therapy to the behavioral treatment for obesity produces weight loss and prevents weight regain.

\section{OUTLINE OF THE THESIS}

For overweight and obese people seeking weight loss treatment, dieticians are the best accessible health care practitioners in the Netherlands. To increase the ecological validity of our findings, our main hypothesis was tested in a relevant field setting. Three of the five studies of this thesis were conducted in the practice of the "Groene Kruis Zorg" IGreen Cross Carel, a Dutch organization of prevention and homecare that offers dietary treatments provided by clieticians.

Our research was started by two studies, conducted to gain a clear understanding of the effectiveness of regular dietary treatments in a field setting (Chapter 2) and the psychological characteristics of the overweight population that registers for such treatments (Chapter 3). Regular dietary treatments for obesity, provided by dieticians, mostly focus on weight reduction 
afid do not touch on psychological variables. As obesity is associated with psychological problems, however, it is interesting to study the effectiveness of regular dietary treatments on measures of psychological well-being. It was questioned whether a regular dietary treatment for obesity that is primarily directed at decreasing weight, also influences concerns about shape, weight and eating, binge eating, mood and self-esteem, without psychological intervention. The results of this study are presented in Chapter 2. Because dietary treatments in field settings are provided in groups but also individually, it was tested whether group and individual treatments were clinically comparable.

We continued our research in the dietary practice by investigating characteristics of overweight and obese people attending the local Green Cross Care centre to lose weight. Comorbid depression has been found to increase morbidity and to worsen treatment outcome in a variety of disorders. The role of depressive symptoms in weight reduction treatment, however, is less clear. The study presented in Chapter 3 examined this relation. It was hypothesized that overweight and obese people with a mild to moderate amount of depressive symptoms would have more shape, weight and eating concerns, score higher on restraint, have lower selfesteem and have a higher BMI than overweight and obese people without depressive symptoms. Furthermore, it was hypothesized that in the group with depressive symptoms, more people would report binge eating than in the non-depressed group.

Following the findings presented in the previous chapters, it was hypothesized that II a cognitive behavioral treatment (CBT) would be more effective in reducing shape, weight and eating concerns, binge eating, and depression, and in improving self-esteem than a standard behavioral treatment (SBT), and that 2) weight losses would be maintained better in the CBT. A cognitive model and a cognitive treatment were developed (Chapter 4), and the effectiweness of the new cognitive behavioral treatment was tested (Chapter 5). Two hundred overweight or obese people were randomly assigned to CBT or SBT. Both treatments aimed at long term maintainable weight losses by changing dietary patterns. Moreover, CBT changed dysfunctional cognitions about shape, weight, eating, the self and relapse, whereas SBT used physical exercise. Measures were taken before treatment, after treatment and one-year after treatment.

The cognitive model of obesity - presented in Chapter 4 - assumes that dysfunctional cognitions aboul eating, weight and shape play an important role in the maintenance of obesity. The model furthermore suggests that a treatment that changes dysfunctional cognitions will succeed in weight loss maintenance. If this is indeed the case, this does, however, not imply that the cognitive model is correct. Two experimental studies were conducted to test part of the cognitive model (Chapter 6 ). In the first study, it was hypothesized that concepts of disinhibition and palatability are associated on an eariy cognitive level, particularly in the obese. This hypothesis was tested within a semantic priming paradigm. The second study investigated associations between the concepts of restraint and palatability within the same paradigm.

Chapter 7 provides the reader with a general discussion of the findings. The results of the studies are discussed and integrated. Clinical implications and directions for future research are given. 


\section{CHAPTER 2}

DIETARY TREATMENT

FOR OBESITY REDUCES BMI

AND IMPROVES EATING PSYCHOPATHOLOGY, SELF-ESTEEM AND MOOD

Submitted for publication as: Werrij, M. Q., Mulkens, S., Hospers, H. J., \& Jansen, A. (2005).

Dietary treatment for obesity reduces BMI and improves eating psychopathology, self-esteem and mood. 


\section{Chapter 2}

\section{ABSTRACT}

In the present study, the hypothesis was tested that a regular dietary treatment for obesity that is primarily directed at decreasing weight, will also decrease concerns about shape, weight and eating, will reduce binge eating, and will improve mood and self-esteem. Moreover, we investigated whether a group treatment and an individual treatment were equally effective. Fifty-four obese participants followed either a group treatment $(n=31)$ or an individual treatment $(n=23)$, provided by dieticians. The data showed that overall, BMI, weight concerns and depressive symptoms decreased and self-esteem increased. The percentage of bingers decreased marginally significantly. For dietary restraint, eating concerns and shape concerns group treatment led to larger changes than individual treatment. The dietary treatment led to improvements in specific eating psychopathology, self-esteem and mood. Contrary to the prevailing opinion that dieting might cause eating problems, the present study shows that dieting in a healthy way might instead be encouraged, especially in overweight and obese people. 
The prevalence of overweight and obesity is increasing worldwide (Visscher, Kromhout, \& Seidell, 2002; Wadden, Brownell, \& Foster, 2002). Currently, behavioural treatments focusing on energy intake and physical exercise are a standard treatment for obesity (Wilson, 1994), and most research has concentrated on the effectiveness of these programs (e.g., Garner \& Wooley, 1991; Jeffery et al., 2000; Wilson, 1994). The effectiveness of conventional dietetic counselling aiming to improve dietary patterns is investigated less extensively, but research suggests that these counselling programs produce short-term weight losses (Katz et al., 2002; Pritchard, Hyndman, \& Taba, 1999; Van den Borne, Geertsma, \& Westmaas Jes, 1988), blood pressure improvements (Pritchard et al., 1999) and even reductions in compulsive eating behaviour, depression and anxiety (Van den Borne et al., 1988).

Randomized clinical trials of dietary treatments mainly focus on weight reduction (Katz et al., 2002; Pritchard et al., 1999; Torgerson, Agren, \& Sjostrom, 1999; Torgerson, Lissner, Lindroos, Kruijer, \& Sjostrom, 1997), leaving psychological variables aside. However, several studies suggest that obesity is associated with psychological problems, such as concerns about appearance (Fairburn \& Cooper, 1993; Marcus, Smith, Santelli, \& Kaye, 1992; Sullivan, 2001; Wilfley, Schwartz, Spurrell, \& Fairburn, 2000), a depressed mood (Kalarchian, Wilson, Brolin, \& Bradley, 1998; Musante, Costanzo, \& Friedman, 1998; Polivy \& Herman, 1992; Porzelius, Houston, Smith, Arfken, \& Fisher, 1995; Sbrocco, Nedegaard, Stone, \& Lewis, 1999; Tanco, Linden, \& Earle, 1998; Telch \& Agras, 1994; Troisi et al., 2001; Venditti, Wing, Jakicic, Butler, \& Marcus, 1996), and low self-esteem (de Zwaan et al., 1994; Quinn \& Crocker, 1999; Striegel Moore, Wilson, Wilfley, Elder, \& Brownell, 1998). Furthermore, a substantial minority of the obese population reports periods of overeating that can be described as binge eating (e.g., Jansen, 1998; Johnsen, Gorin, Stone, \& le Grange, 2003). Recent cognitive behavioural models of obesity state that concerns about shape, weight and eating and self-esteem play an important role in the maintenance of obesity [Cooper \& Fairburn, 2001; Nauta, Hospers, Kok, \& Jansen, 20001 , and cognitive therapy - directed at identifying and changing those dysfunctional concerns - is put forward as a promising means in obesity treatment. Regular dietary treatments aim to change dietary patterns, and are not specifically directed at changing psychological characteristics. Interestingly however, psychological outcomes are rarely studied after those treatments. Is it necessary to treat obese people with psychotherapeutic interventions, in order to change concerns about shape, weight and eating, depressed mood and low self esteem? Or is regular dietary treatment sufficient to change these psychological states? Concerns about appearance are not so strange in overweight people. So possibly, weight reduction is accompanied by decreased appearance related concerns and improved mood and self-esteem as well. We hypothesized that a regular dietary treatment for obesity that is primarily directed at decreasing weight, also decreases concerns about shape, weight and eating, reduces binge eating, and improves mood and self-esteem, without psychological intervention. Because dietary treatments in field settings are provided in groups but also individually, it is of practical interest to test whether group and individual treatments are equally effective. 


\section{Method}

\section{Participants}

Participants were 59 overweight and obese people who registered for a regular dietary treatment by a dietician. Main inclusion criteria were BMI $>25$ and age above 18 years. Five persons were excluded from the analyses because they had too many missing values $(>10 \%)$. The final study sample thus included 54 overweight/ obese people.

\section{Treatment}

The dietary treatment was carried out by dieticians and aimed at weight losses of $0.5 \mathrm{~kg}$ per week, up to a total weight loss of $5.10 \%$, by changing dietary patterns. Treatment was provided in groups or on individual basis. Participants enlisted for either treatment modality by choice. In the group treatment, ten weekly 75 -minutes sessions were offered. In addition to nutritional counselling, treatment focussed on a regular eating pattern, setting realistic goals, identifying high-risk situations, self-monitoring and motivation to exercise. In the individual treatment, nine 15-minutes session were offered after a 60-minutes intake. Nutritional counselling was personally tailored as is standard practice.

\section{Measures}

Weight and height (BMI) were collected from dieticians' patient records. Specific eating psychopathology was measured with the EDEO (Eating Disorder Examination - Questionnaire; Fairburn \& Beglin, 1994), 36-item questionnaire that measures concerns about shape, weight and eating and binge eating. Subscale scores for shape, weight and eating concerns and restraint ranged between $0-6$. A higher score indicates more severe eating psychopathology. Binge eating was measured as a dichotomous variable (binger / non-binger). Self-esteem was measured with the RSE (Rosenberg Self-Esteem Scale; Rosenberg, 1965). The RSE measures global selfesteem and consists of 10 items. A higher score indicates a more positive self-esteem. Mood was measured with the BDI (Beck Depression Inventory; Beck, Ward, Mendelson, Mock, \& Erbaugh, 1961). The BDI measures the severity of depressive symptoms and consists of 21 items. One item about weight loss was excluded from analyses and the sum of the remaining 20 items was calculated. A higher score indicates more depressive symptoms. Measures were taken pre- and post treatment.

\section{Statistical analyses}

Missing items were replaced by the mean score on the remaining items of the scale (EDEO, RSE, BDI). Data were analysed in 2 (time: pretreatment vs. posttreatment) $x 2$ (group: individual vs. group treatment) repeated measures ANOVA's. The results section is structured according to our hypotheses. First, main effects of time are reported to test our main hypothesis. Second, time $\mathrm{x}$ group interactions are reported to investigate differences between the treatments (individual and group). For significant interactions, paired samples ttests were conducted per 
group. For BMI, group differences were not examined due to a limited posttreatment sample in the individual treatment $(n=5)$. Therefore for $\mathrm{BMI}$, a paired samples ttest was performed to investigate the main effect of time. The McNemar test for paired proportions was used to test overall changes in the percentages of bingers. Differences between the treatments concerning changes in the percentage of bingers were investigated by chi-square analyses. Correlation anallyses provided insight in the relation between changes in BMI on the one hand and changes on specific eating psychopathology (EDEQ), self-esteem (RSE) and mood (BDI) on the other hand.

\section{RESULTS}

\section{Participant characteristics}

Before treatment, participants in the two treatments were comparable on age, sex, and main outcome measures (all p-values $n s$ ), but EDEO restraint scores tended to be higher in the individual treatment (Tables 2.1 and 2.2).

Table 2.1: Age and sex per treatment condition

\begin{tabular}{|c|c|c|}
\hline & $\begin{array}{l}\text { Individual Treatment } \\
\qquad n=23\end{array}$ & $\begin{array}{l}\text { Group Treatment } \\
n=3\end{array}$ \\
\hline Age (SD) & $45(1689)$ & $45(1099)$ \\
\hline Sex Femalle & $87 \%$ & $94 \%$ \\
\hline Male & $13 \%$ & $6 \%$ \\
\hline
\end{tabular}

\section{Main hypothesis}

In support with our main hypothesis, main effects of time were found for BMI, EDEQ weight concerns, RSE, and BDI (Table 2.2). After treatment, BMI, weight concerns and depressive symptoms decreased, and selfesteem increased. Main effects of time were also significant for EDEO restraint and EDEQ shape concerns. However, these main effects were qualified by a significant time $\mathrm{x}$ group interaction for EDEO restraint and a marginally significant interaction for EDEQ shape concerns (described below). The main effect of time for EDEQ eating concerns was not significant. The percentage of bingers decreased marginally significantly.

\section{Differences between the treatments}

Time $\mathrm{x}$ group interactions were significant for EDEQ restraint and EDEQ eating concerns (Table 2.2). Restraint scores remained the same after individual treatment, but increased after group treatment. Eating concerns remained the same after individual treatment, but decreased after group 
Chapter 2

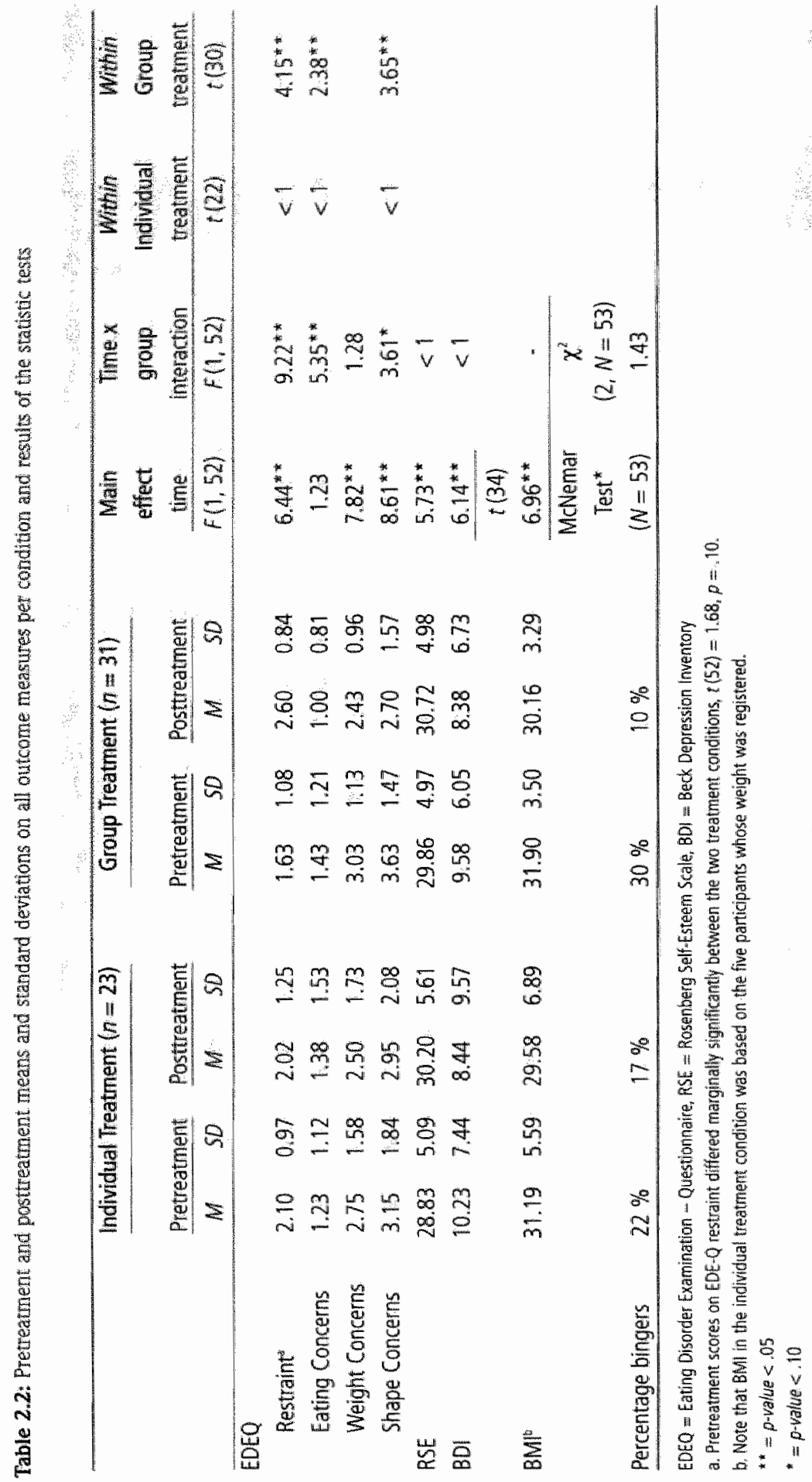


treatment. For EDEQ shape concerns the time $\mathrm{x}$ group interaction was marginally significant. Although means suggest that both treatments reduced shape concerns, this effect was only significant for the group treatment. The time $x$ group interaction was not significant for EDE$Q$ weight concerns, self-esteem, and mood. The main effect of group was not significant for any of the outcome measures (all $F$ 's $<1$ ). Changes in the percentage of bingers did not differ significantly between the treatments.

\section{Correlation analyses}

Pretreatment to postreatment changes in BMI were significantly related to changes in shape concerns, $r=.43, p<.01$. Participants with a stronger decrease in BMI after treatment reported a stronger decrease in shape concerns. Larger BMI reductions tended to be related to a stronger increase in restraint, $r=-.32, p<.06$ and to a stronger decrease in weight concerns, $r=.32$, $p<.06$. None of the other correlations were significant.

\section{Discussion}

In this study, we investigated whether a regular dietary treatment for obesity, directed at weight reduction, also improves eating psychopathology, self-esteem and mood. Overall, the dietary treatment led to significant weight loss, decreased weight concerns and depressive symptoms, and increased self-esteem. The percentage of bingers tended to decrease. Differences between the treatments emerged for restraint, eating concerns and shape concerns. After group treatment, restraint increased and eating concerns decreased whereas after individual treatment, these factors did not change. Furthermore, though means suggest that both treatments reduced shape concerns, group treatment tended to be more effective in reducing these concerns. In reducing concerns about eating and shape, group treatment at least tended to be superior.

BMI decreased significantly. Though there were not enough BMI data in the individual treatment to study treatment differences, the data show that overall, participants lost weight. Reductions in BMI were significantly correlated to decreased concerns about shape, and tended to be related to increased restraint and decreased concerns about weight. Bearing in mind that BMI data were only available for part of the sample, these data suggest that even modest weight losses are related to decreased in concerns about weight and shape. Surprisingly, no evidence was found in the present study for a correlation between weight loss on the one hand, and improvements in self-esteem or mood on the other hand. Clearly, these factors were unrelated.

Interestingly, the present study shows that dietary treatment, directed at reducing weight, is also successful in changing eating related and general psychopathology, although these psychological factors did not receive attention in these treatments. Do these data suggest that recently promoted treatments considering an important role of cognitions in the maintenance of obesity, and promoting cognitive therapy in treating obesity (Cooper \& Fairburn, 2001; Nauta, 
Hospers, Kok, et al., 2000), are superfluous? Do they suggest that concerns about appearance, mood and selfesteem are only an artefact of being obese, and that dietary treatment is sufficient in effectively improving these measures of psychological well-being? Concerning the short-term effectiveness of dietary treatments, this might be the case, although only a small sample was used in the present study. The question remains whether participants will maintain their weight in the long run. It is now well known that the long-term effectiveness of behavioural programs for obesity is at least disappointing (Garner \& Wooley, 1991; Jeffery et al., 2000; Wilson, 1994). Presumably, regaining weight brings back concerns about appearance and depressive symptoms, and decreases self-esteem. The development of treatments that help people maintain their weight remains very important, and cognitive therapy might be a promising means to improve current treatments (Cooper \& Fairburn, 2001; Nauta, Hospers, Kok, et al., 2000).

Restraint scores increased after group treatment. According to restraint theory, dieting precedes binge eating (Polivy \& Herman, 1985; 1993). However, support for this model is inconsistent (Presnell \& Stice, 2003; Stice, 2002). The present data suggest that concerns about eating, weight and shape decreased after treatment. The percentage of bingers tended to decrease. Although the reduction in the percentage of bingers was only marginally significant, the hypothesis that dieting increases the risk for the onset of bulimic pathology was surely not supported by the data.

The current study investigated weight loss related improvements on eating psychopathology, self-esteem and mood after a regular dietary treatment. The study was therefore performed in a field setting, which was accompanied by several methodological shortcomings. Due to practical constraints a limited amount of participants could be followed through treatment. Because treatment effects were investigated in a regular practical setting, assignment to treatment condition could not occur at random. Furthermore, there was no no-treatment control group. And finally, being dependent on questionnaires, binge eating could not be investigated optimally (Fairburn \& Beglin, 1994; Kalarchian, Wilson, Brolin, \& Bradley, 2000).

\section{Conclusions}

In the present study, weight reduction related changes on eating psychopathology, self-esteem and mood were studied aiter a regular dietary treatment for obesity. Although there was no specific attention for psychological variables in the treatment, weight concerns and depressive symptoms decreased, and self-esteem increased. In reducing eating and shape concerns, group treatment was more effective than individual treatment. However, it remains unclear whether weight regain will undo these psychological advantages. Though restraint scores increased after group treatment, the assumption that restraint leads to binge eating was not supported by the data. Contrary to the prevailing opinion that dieting might cause eating problems and should be discouraged, the present study suggests that healthy dieting might instead be encouraged, especially in overweight and obese people. 


\section{CHAPTER 3}

\section{OVERWEIGHT AND OBESITY: \\ THE SIGNIFICANCE OF A DEPRESSED MOOD}

Accepted for publication as: Werrij, M. Q., Mulkens, S., Hospers, H. J., \& Jansen, A. (in press). Overweight and obesity: the significance of a depressed mood. Patient Education and Counseling. 
Chapter 3

\section{ABSTRACT}

Comorbid depression has been found to increase morbidity in a variety of disorders. This study aimed to investigate whether the presence of depressive symptoms in overweight and obese people is related to increased specific eating psychopathology and decreased self-esteem. Overweight /obese people seeking dietary treatment were grouped according to their scores on the Beck Depression Inventory (BDI), resulting in a mildly to moderately depressed group $(B D I \geq 10 ; n=66$; the symptomatic group) and a non-depressed group (BDI $<10 ; n=83$ ). Eating psychopathology was measured by the Eating Disorder Examination - Questionnaire; self-esteem was measured by the Rosenberg Self-Esteem Scale. Symptomatic people had more shape, weight and eating concerns ( $p$-values $<0.001)$; scored higher on restraint $(p<0.01)$; had lower self-esteem $(p<0.001)$; and had a higher BMI $(p<0.05)$ than non-depressed people. Furthermore, the percentage of bingers was higher in the symptomatic group $(p<0.01)$. Symptomatic participants suffered more than non-depressed participants, and not only from their depression. For dieticians treating overweight and obese people, the BDI is a useful instrument for identifying the subgroup with depressive symptoms - the group that is at risk for (eating) psychopathology. 
Depression has been found to coexist with a diversity of disorders, both medical - for example, cancer, cardiovascular diseases, theumatoid arthritis or diabetes - and psychiatric - for example, anxiety disorders (Mendlewics, 19981. Morbidity in patients suffering from these disorders generally increases when comorbid depression is present (Mendlewics, 1998). Treatment outcome is also influenced by depression. In the treatment of obsessive compulsive disorder (OCD), for example, non-depressed patients benefited more from treatment than depressed patients (Abramowitz \& Foa, 2000; Overbeek, Schruers, Vermetten, \& Griez, 2002). Patients with comorbid depression might, therefore, be treated more effectively with an integrated approach in which depression status is taken into account, as was suggested for the treatment of panic disorder (Johnson \& Lydiard, 1998) and substance use disorder (Charney, Paraherakis, \& Gill, 2001).

The role of comorbid depression in weight reduction treatment is less clean. There is some evidence that overweight and obese people suffer from depressive symptoms, as several studies found participants to be mildly to moderately depressed (Kalarchian, Wilson, Brolin, \& Bradley, 1998; Musante, Costanzo, \& Friedman, 1998; Polivy \& Herman, 1992; Porzelius, Houston, Smith, Arfken, \& Fisher, 1995; Tanco, Linden, \& Earle, 1998; Telch \& Agras, 1994; Troisi et al., 2001). Moreover, a positive association between obesity and depression has been reported frequently (Dong, Sanchez, \& Price, 2004; Jorm et al., 2003; McElroy et al., 2004; Roberts, Deleger, Strawbridge, \& Kaplan, 2003; Rosmond, 2004; Stunkard, Faith, \& Allison, 2003). However, other studies have found minimal or no depressive symptoms in overweight/obese people (Porzelius et al., 1995; Sbrocco, Nedegaard, Stone, \& Lewis, 1999; Venditti, Wing, Jakicic, Butler, \& Marcus, 1996); no association between obesity and depression (Friedman \& Brownell, 1995); or even found lower levels of depression in obese middle-aged men (Crisp \& McGuiness, 1976; Palinkas, Wingard, \& Barrett-Connor, 1996). High levels of depression were found to be associated with treatment attrition (Clark, Niaura, King, \& Pera, 1996). Furthermore, research by Sherwood, Jeffery, and Wing (1999) suggests that depression mediates the relationship between binge eating and weight loss. The positive relationship between changes in binge eating and weight change was no longer significant when depression scores were added to the regression analyses.

In sum, depression occurs with a variety of disorders; generally aggravates symptoms in patients with comorbid depression; and can adversely affect treatment outcomes. Adapting treatment to the depression status of a patient might improve its outcome. In overweight and obesity, the presence of depressive symptomatology is no exception. Overweight and obese people in the Netherlands seeking help for their weight problems usually register for diet management provided by dieticians. In the clinical practice of these dieticians, the treatment is generally focused on dietary patterns, without concern for psychological symptoms such as depression. Because comorbid depressive symptoms may affect treatment outcome, it is highly relevant for dieticians to know whether comorbid depressive symptomatology in their patients is related to increased specific eating psychopathology and decreased self-esteem. As a consequence, this subgroup may be more difficult to treat. 
The present study investigated whether the presence of depressive symptoms in overweight and obese people registering for dietary treatment in a regular clinical setting is related to increased specific eating psychopathology (i.e., concerns about shape, weight and eating, restraint, and binge eating), and low selfesteem. We hypothesised that overweight and obese people with depressive symptoms are more concerned about shape, weight and eating, have a more restrained eating style, lower self-esteem, and a higher BMI than non-depressed overweight and obese people. We further hypothesised that in the symptomatic group, more participants report binge eating than in the non-depressed group.

\section{MethoD}

\section{Participants}

Participants were comprised of overweight and obese people seeking dietary treatment for their weight problems (BMI $>25)$. All participants enlisted for individual or group treatment in a Dutch community centre offering dietary treatments for overweight and obesity. When registering for the dietary treatment, participants were invited to participate in the study. Initially, 224 people registered for the study. However, 58 peaple were excluded because their BMI was lower than $25(n=4)$ or unknown $(n=54)$. The study sample thus consisted of 166 overweight and obese people.

\section{Procedure}

Questionnaires were mailed to the participants and collected by the dietician at the first appointment.

\section{Measures}

Welght and height were recorded by the dietician. Participants were weighed in street clothes, without shoes. Body Mass Incex $\left(B M I=\right.$ weight $(\mathrm{kg}) /$ height $\left.(\mathrm{m})^{2}\right)$ was calculated.

Specific eating psychopathology was measured using the Eating Disorder Examination Questionmaire (EDE-O; Fairbum \& Beglin, 1994), a 36-item questionnaire that measures concerns about shape, weight and eating, restraint and self-reported binge eating. Subscale scores for shape, weight and eating concerns and restraint ranged between 0 and 6 . A higher score indicates more severe eating psychopathology.

Depression was measured with the 21 -item Beck Depression Inventory (BDI; Beck, Ward, Mendelson, Mock, \& Erbaugh, 1961 ]. The BDI measures the severity of depressive symptomatology. Items are scored on a 4 point scale. One item about weight lass was excluded from the analysis and the sum of the remaining 20 items was calculated. A higher score indicates more severe depression. Scores below 10 are considered normal; a score of 10 or more indicates mild to moderate depression (Beck, Steer, \& Garbin, 1988). 
Self-esteem was measured using the Rosenberg Self-Esteem Scale (RSE; Rosenberg, 1965). The RSE is a 10-item questionnaire that measures global self-esteem. Items are scored on a 4point scale. A higher score indicates more positive self-esteem. Scores below 21 indicate low self-esteem (Rosenberg, 1979).

\section{Statistical analyses}

A missing value analysis was conducted to replace missing data. The number of missing values for each questionnaire (EDE-Q, BDI, RSE) was calculated for each participant. Those with fewer than $10 \%$ missing values on each of the questionnaires were included in the analyses $(n=149)$. For those participants, missing item scores were replaced by the mean score of the other participants for those particular items.

Participants were grouped according to the cut-off scores for the BDI (cut-off $=10$ ) (Beck et al., 1988). Accordingly, two groups were created. The symptomatic group consisted of participants with mild to moderate depression (BDI $\geq 10, n=66$ ); the non-depressed group consisted of participants without any or with a minimal number of depressive symptoms ( $\mathrm{BDI}<10, n=83$ ).

To test our hypotheses, $t$-tests on the four subscales of the EDE- $\mathrm{a}$, the RSE and BMI were performed with depressive symptomatology (symptomatic versus non-depressed) as a between subjects factor. If Levene's test for equality of variances showed significance, results of the t-test with equality of variances not assumed were reported. A Chi-square analysis was conducted to investigate whether the percentage of participants reporting objective eating binges differed between the symptomatic and the non-depressed group.

\section{Results}

\section{Participant characteristics}

Characteristics of participants (age, sex) are presented in Table 3.1. Symptomatic and nondepressed participants did not differ with respect to age, $t(137)<1$, or sex, $\left.\chi^{2}(1, N=149)\right\}$ $=1.8, p=n s, r=0.11$. As expected, symptomatic and non-depressed participants' BDI scores differed significantly, $t(84.2)=15.2, p<0.001$.

\section{Differences between symptomatic and non-depressed participants}

We hypothesised that overweight and obese participants with depressive symptoms would be more concerned about their shape, weight and eating, have a more restrained eating style, lower self-esteem, and a higher BMI than non-depressed overweight and obese participants. We further hypothesised that in the symptomatic group, more participants would report binge eating than in the non-depressed group.

As predicted, $t$ tests revealed significant differences in EDE-O shape concerns, $t(145.3)=5.7$, $p<0.001$; EDE- $Q$ weight concerns, $t(147)=6.0, p<0.001$; EDE-Q eating concerns, $t(107.6)$ 
Table 3.1. Age, sex, BDI, EDEO, RSE and BMI of participants.

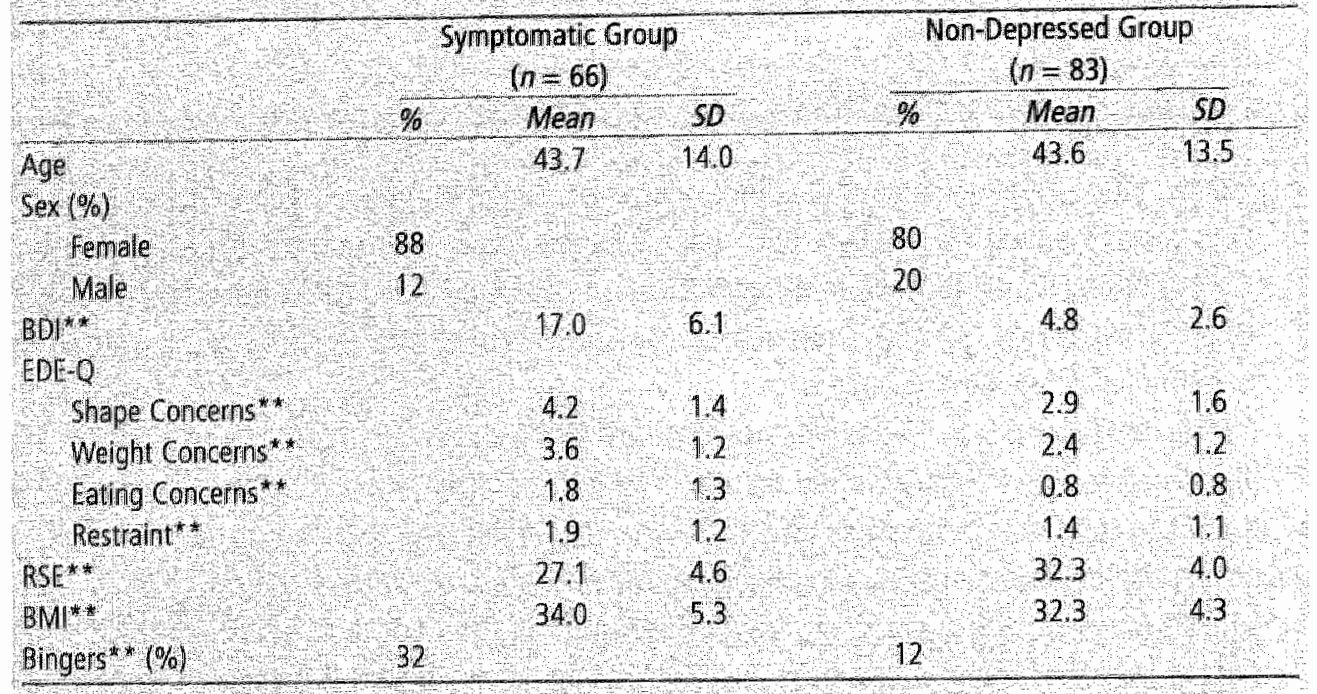

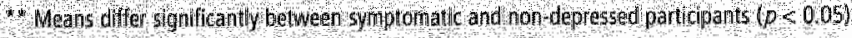

$=5.2, p<0.001$; EDE-Q restraint, $t[147\}=2.8, p<0.01$; RSE, $t\{147\}=7.4, p<0.001$; and $\mathrm{BMI}_{,} t(147)=2.0, p<0.05$. Inspection of the means shows that, as expected, symptomatic participants were more concerned about shape, weight and eating; scored higher on restraint; had lower self-esteem; and had a higher BMI than non-depressed participants (see Table 3.1 for means on all outcome measures).

The Chi-square analysis revealed that the percentage of participants reporting eating binges differed significantly between symptomatic and non-depressed participarts, $\chi^{2}(1, N=148)=$ $8.5, p<0.01, m=0.24$. As hypothesised, in the symptomatic group, more participants reported binge eating than in the non-depressed group (Table 3.11).

\section{Overweight versus obese participants}

Within the study sample, 47 participants were overweight (BMI $25-30$ ) and 102 were obese $[\mathrm{BM}] \geq 30$; BM] correlated significantly with BDI scores $[r=0.23, p<0.01\}$. To determine whether the pattern of results would be maintained for each weight group, we conducted analyses for the overweight and obese groups separately. Using the same cut-off scores as in the total group, we found 17 symptomatic and 30 non-depressed participants in the overweight group, and 49 symptomatic and 53 non-depressed participants in the obese group. Analysing data for the two weight groups separately did not change the results substantially. In the obese group (Table 3.2), symptomatic participants were more concerned about their weight, shape and eating, scored higher on restraint, and had lower self-esteem (all pvalues $<0.02$ ) than the 
Table 3.2: BDI, EDE-Q, RSE and BMI of obese participants.

\begin{tabular}{|c|c|c|c|c|c|c|}
\hline & \multicolumn{3}{|c|}{$\begin{array}{c}\text { Symptomiatic Group } \\
(n=49)\end{array}$} & \multicolumn{3}{|c|}{$\begin{array}{c}\text { Non-Depressed Group } \\
(\eta=53)\end{array}$} \\
\hline & $\%$ & Mean & SD & $\%$ & Mean & 50 \\
\hline $\mathrm{BDI}^{* *}$ & & 175 & 6.5 & & 47 & 25 \\
\hline \multicolumn{7}{|l|}{ EDE $-Q$} \\
\hline Shape Concerns ${ }^{* *}$ & & 4,3 & 15 & & 28 & 17 \\
\hline Weight Concerns ${ }^{*}$ : & & 38 & 13 & & 24 & 13 \\
\hline Eating Concerins* & 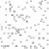 & 19 & 13 & & 0.8 & 09 \\
\hline Restraint** & & 20 & 1,1 & & 14 & 12 \\
\hline RSE $^{* *}$ & & 26.5 & 45 & & 327 & 42 \\
\hline BMI & & 35.8 & 4.8 & & 34.6 & 37 \\
\hline Bingers $^{*}(\%)$ & 33 & & & 12 & & \\
\hline
\end{tabular}

** Means differ significantly between symptomatic and non depressed participants $(p<0.05)$

non-depressed participants. Furthermore, the percentage of participants reporting eating binges was higher in the symptomatic group $(p<0.02)$. BMI differences were in the same direction as in the group as a whole, but not significant. In the overweight group (Table 3.3), the pattern of results was similar to that of the group as a whole, but because of an apparent power problem, some of the findings were no longer significant. Symptomatic participants were more concerned about their shape, had lower self-esteern ( $p$-values $<0.03$ ), and tended to be more concerned

Table 3.3: BDI, EDE-Q, RSE and BMI of overweight participants.

\begin{tabular}{|c|c|c|c|c|c|c|}
\hline & \multicolumn{3}{|c|}{$\begin{array}{l}\text { Symptomatic Group } \\
(n=17)\end{array}$} & \multicolumn{3}{|c|}{$\begin{array}{l}\text { Nom-Depressed Group } \\
(n=30)\end{array}$} \\
\hline & $\%$ & Mean & 50 & $\%$ & Mean & $5 D$ \\
\hline $\mathrm{BDI} * *$ & & 15.5 & 4.8 & & 4.9 & 2.9 \\
\hline \multicolumn{7}{|l|}{$\mathrm{EDE}-\mathrm{Q}$} \\
\hline Shape Concerns* & & 4.0 & 1.2 & & 3.0 & 1.3 \\
\hline Weight Concerns & & 3,0 & 1.0 & & 2.5 & 1.0 \\
\hline Eating Concerns" & & 1.3 & 0.9 & & 0.9 & 0.7 \\
\hline Restraint & & 1.8 & 1.3 & & 1.4 & 0.8 \\
\hline RSE** & & 28.8 & 4.6 & & 31.6 & 3.4 \\
\hline$B M I$ & & 28.5 & 1.2 & & 28.3 & 1.3 \\
\hline Bingers (\%) & 29 & 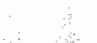 & & 13 & & \\
\hline
\end{tabular}

** Means differ significamly between symptomatic and non-deptessed participants $(p<0.05)$

* Meams differ marginally significantly between symptomatic and nom-depressed participants $(p<0.11)$ 
about their weight and eating [ $p$ values $<0.11]$ than non-depressed participants. For restraint, BMI and the percentage of binge eaters, the results were similar to those of the total group, but differences were not significant.

\section{Bingers versus non-bingers}

In the symptomatic group, more participants reported binge eating than in the non-depressed group. To test whether the psychopathology in the symptomatic group could be attributed entirely to the binge eaters in this group, all bingers were removed from the analyses. Analyses of the non bingers alone did not change the results substantially. Symptomatic participants again were more concerned about their weight, shape and eating; scored higher on restraint; had lower selfesteem; and had a higher BMI than non-depressed participants (all pvalues < 0.05 ) (Table 3.4).

Thble 3, BDI, EDE-Q, RSE and BMI of non-bingers.

\begin{tabular}{|c|c|c|c|c|}
\hline & \multicolumn{2}{|c|}{$\begin{array}{c}\text { Symptomatic Group } \\
(n=45)\end{array}$} & \multicolumn{2}{|c|}{$\begin{array}{l}\text { Non-Depressed Group } \\
\quad(n=72)\end{array}$} \\
\hline & Mean & 50 & Mean & SD \\
\hline $\mathrm{BD}{ }^{* *}$ & 163 & 58 & 45 & 2.6 \\
\hline EDEO & & & & $\%$ \\
\hline Shape Concerns* : & 4.1 & 1.5 & 27 & 1.6 \\
\hline Weight concerns* & 35 & 1.4 & 23 & 12 \\
\hline Eating Concerns" * & 1.4 & 12 & 0.7 & 0.8 \\
\hline Restraint** & 18 & 11 & 1.4 & 1, \\
\hline RSE: : & 277 & 43 & 325 & 4.0 \\
\hline $\mathrm{BM}^{* *}$ & 34.3 & 5.2 & 32.4 & 4.4 \\
\hline
\end{tabular}

A Mear s difer signifianty between sympionatic and not depressed pantic cents $(a<005)$

\section{Discussion and Conclusion}

\section{Discussion}

The present study investigated whether depressive symptoms in overweight and obese people seeking dietary treatment are related to increased specific eating pathology (i.e., shape-, weightand eating concerns, eating restraint, and binge eating) and low self-esteem. In accordance with our hypotheses, we found that symptomatic participants had more shape, weight and eating concerns, a more restrained eating style, lower self-esteem and a higher BMI than non-depressed participants. Moreover, in the symptomatic group, more participants reported binge eating than in the non-depressed group.

It is noteworthy that almost half (44\%) of a community sample that registered for dietary 
weight loss treatment scored 10 or higher on the BDI, and thus exhibited some symptoms of mild to moderately severe depression (Beck et al., 1988). Of course, an accurate clinical diagnosis of depression is necessary before concluding that these participants were depressed; but the present data show that depressive symptoms may be more common in overweight and obese people than we think.

As reviewed in the introduction, comorbid depression generally exacerbates several disorders and treatment outcomes. Therefore, treating the depression might improve treatment success. This study points to an overwhelming amount of depressive symptoms in the overweight/obese population. At the same time, depressive symptoms were accompanied by appearance and eatingrelated worries, a restrained eating style, low selfesteem and eating binges. In sum, these results suggest that providers of weight reduction programmes should take into consideration the level of depressive symptoms in overweight and obese people who participate in these programmes.

Participants with mild to moderate depression had a higher BMI than non-depressed participants. Furthermore, the significant correlation between BMI and BDI scores suggests that the chance of depressive symptoms increases when BMI rises. Could it simply be that BMI accounts for the elevated levels of specific eating psychopathology and lowered self-esteem in the symptomatic group? This explanation is not likely for two reasons. First, the present data show that when overweight and obese people were analysed separately, symptomatic as well as non-depressed people were found within each weight group, though all participants in the overweight group had a lower BMI than those in the obese group. Thus, being overweight (rather than obese) is no guarantee that depression will not be a factor, as about one-third of the overweight group was symptomatic. Moreover, obesity is not necessarily accompanied with depression, as about half of the obese group was not depressed. Furthermore, symptomatic people still showed higher levels of psychopathology than non-depressed participants in these separate analyses, whereas importantly, BMI differences were not significant. This pattern of results appeared in both weight groups, though because of an apparent power problem, some findings were no longer significant in the overweight group. In conclusion, although $\mathrm{BMI}$ and depressive symptoms were related, these findings clearly suggest that BMI alone is not enough to account for the elevated psychopathology in the symptomatic group.

Second, several previous studies suggest that BMI alone does not account for psychopathology in obese people; mediating factors such as binge eating (De Zwaan et al., 1994; Isnard et al., 2003; Johnsen, Gorin, Stone, \& Le Grange, 2003; Picot \& Lilenfeld, 2003; Telch \& Agras, 1994; Venditti et al., 1996) or body dissatisfaction (Cargill, Clark, Pera, Niaura, \& Abrams, 1909; Wardle, Waller, \& Rapoport, 2001) play a prominent role. The causal relationship between binge eating, psychopathology and BMI, however, has not been established yet; most data is correlational in nature. The present data show that even when the bingers were removed from the analyses, the symptomatic group still showed higher levels of psychopathology. Apart from binge eating, negative affect plays a central role. However, causality cannot be determined from our data; we still do not know which factor - depression, body dissatisfaction, binge eating, or something else - causes the (eating) psychopathology in obese people. 


\section{Conclusion}

About one in every two participants registering for dietary treatment exhibited some symptoms of depression. These symptomatic participants were more concerned about shape, weight and eating; had a more restrained eating style; lower self-esteem; and a higher BMI than nondepressed participants. Moreover, in the symptomatic group, more participants reported binge eating than in the non-depressed group. The symptomatic participants clearly suffered more than their non-depressed co-participants, and not only from their depression.

\section{Practice Implications}

The present study clearly shows that even mild to moderate depressive symptoms indicate the presence of specific eating pathology and low self-esteem in overweight and obese people. As discussed previously, however, it is not yet known which factor (e.g., binge eating, body dissatisfaction, depression or something else] causes psychopathology in obese people. In identifying this subgroup with psychological problems, it may be of practical importance to focus on the person's depression status. Binge eating is not easily determined and binge selfreports are often criticised for being unreliable (Fairburn \& Beglin, 1994; Kalarchian, Wilson, Brolin, \& Bradley, 2000); whereas the BDI is a reliable measure of depressive symptomatology (Beck et al., 1988; Richter, Werner, Heerlein, Kraus, \& Sauer, 1998). For practical reasons, dieticians can focus on the depression status of their overweight and obese patients to select those people who are at risk for psychological problems. Whether or not adapting treatment for obesity to a patient's depression status would improve treatment outcome remains to be investigated. However, adding cognitive therapy to the behavioural dietary treatment might be a rewarding enterprise (Nauta, Hospers, Kok, \& Jansen, 2000). For dieticians or other health care providers, the BDI could be used as an easy and helpful tool to select and refer overweight and obese people with depressive symptoms to an appropriately trained psychotherapist. 


\section{CHAPTER 4}

THE COGNITIVE MODEL

AND TREATMENT 
This chapter provides a detailed description of the treatment protocol for the cognitive treatment. First, a cognitive model of the maintenance of obesity is presented. Next, a treatment protocol, derived from the cognitive model, is described.

\section{THE COGNITIVE MODEL OF THE MAINTENANCE OF OBESITY}

The cognitive behavioral treatment of bulimia nervosa, developed by Fairburn and colleagues (1993), is strongly based on a cognitive model of the maintenance of the disorder. In this model, dysfunctional concerns about weight and shape play a central role (Fairburn, Marcus, \& Wilson, 1993]. Based on this original model, and on adapted versions of the model for bulimia nervosa [Meijboom \& Jansen, 1999) and obesity (Nauta, Hospers, Kok, \& Jansen, 2000) a new cognitive model of the maintenance of obesity was developed (Figure 4.1).

Concerns about weight and shape may play an important role in the maintenance of obesity as well (Nauta, Hospers, Jansen, \& Kok, 2000). Obese people were found to be more concerned about their weight and shape then people of normal weight (Fairburn \& Cooper, 1993; Wilfley et al., 2000\}. Levels of these concerns in obese binge eaters were even comparable to those in bulimia nerrosa patients (Marcus, Smith, Santelli, \& Kaye, 1992; Masheb \& Grilo, 2000; Sulliwan, 2001; Wilfley et al., 2000). Concerns about eating did not differ between obese people in general and people of normal weight (Fairburn \& Cooper, 1993; Wilfley et al., 2000), but obese binge eaters scored higher on this measure than normal weight controls (Marcus et al., 1992; Sullivan, 2001; Wilfley et al., 2000). The model we propose explains the maintenance of obesity by assigning a major role to dysfunctional cognitions about eating, weight and shape. These dysfunctional cognitions are elicited by specific situations, and they cause (dysfunctional) emotions and behavior (see also Beck, 1976). Relevant situations for eliciting thoughts about eating, weight and shape are for example being at a party (eating-related thoughts) or being in a fitting room (appearance-related thoughts).

According to our model, dysfunctional cognitions about shape and weight result in (inadequate) dieting attempts ${ }^{1}$ (1) (Fairburn et al., 1993; Fairburn, Cooper, \& Shafran, 2003). Examples of these weight or shape related cognitions may be "When l'm as fat as now, ] will never find nice clothes" or "If I lose ten kilos, all my problems will be solved". Consistently, obese people were found to score high on measures of dietary restraint (Heatherton, Herman, Polivy, King, \& McGree, 1988; Ruderman, 1986; but see: Wilfley et al., 2000). These attempts to control weight, however, are ultimately not adequate, not only because the foverweight) person obvious]y is still too heavy, but also because the attempts are often rigid ( 2 ). Physically, obesity is maintained by an imbalance between energy intake and expenditure. This is reflected by the "overeating" box in the model. This overeating does not by definition refer to binge

1. The bold numbers in the text below refar to the coresponding alrows in figuta 4.1 . 
eating, but rather to this energy imbalance. With respect to the causal relation between restraint and binge eating, evidence is equivocal. Supporting restraint theory (Polivy \& Herman, 1985; 1993), evidence for a relation between (self-reported) dieting and binge eating was found in several studies (Herman \& Mack, 1975; Ruderman, 1986; Stice, 2002). However, no evidence for a relationship between these two factors was found in clinical trials in which calorie intake was manipulated (Presnell \& Stice, 2003; Stice 2002). Recent studies suggest that a third variable (1.e.,. tendency to overeat or impulsivity), accounting for both dieting and overeating, may explain these inconclusive findings Jansen et al, 2003; Nederkoorn, Van Eijs, \& Jansen, 2004; Ouwens, Van Strien, \& Van der Staak, 2003; Stice, 2002).

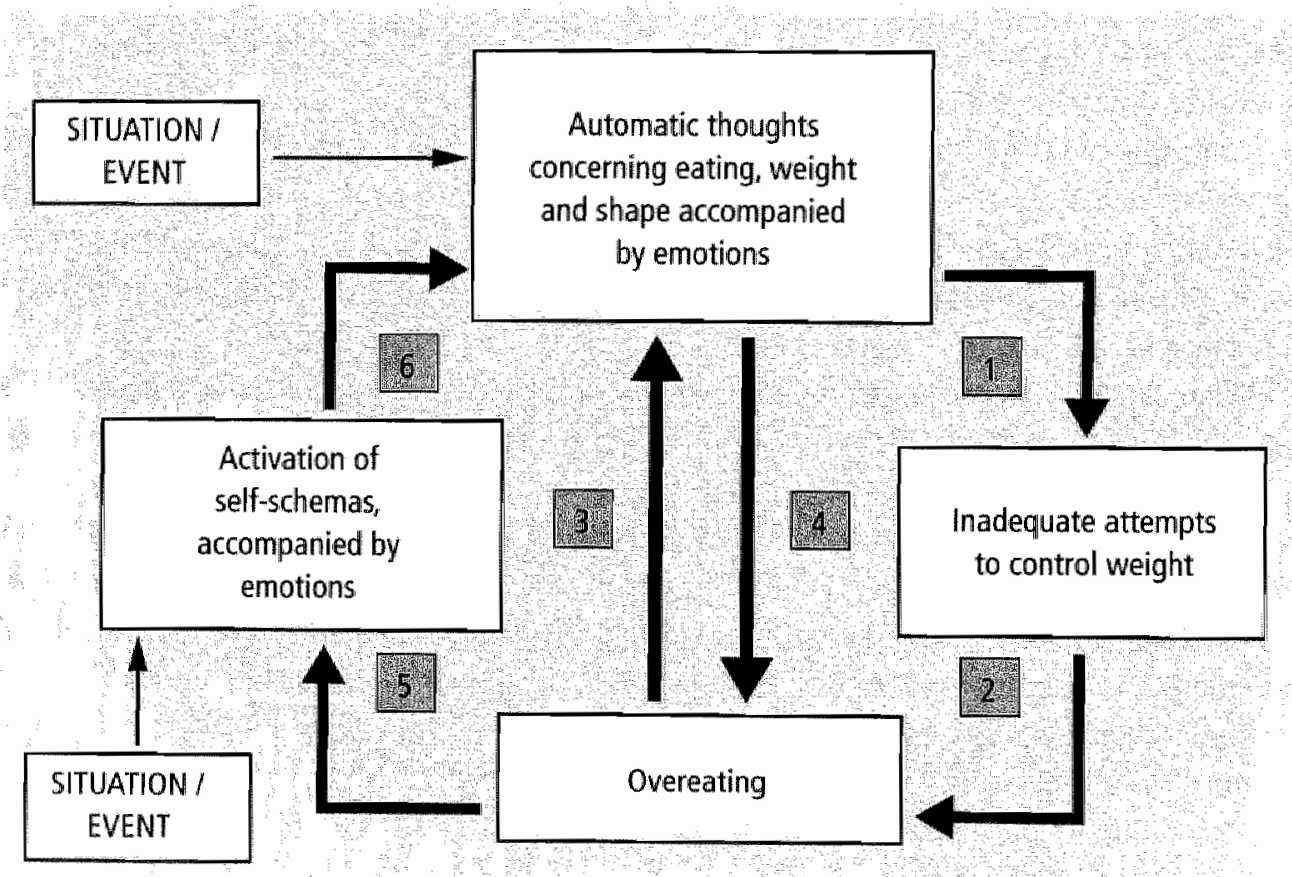

Figure 4.1: The cognitive model of the maintenance of obesity

The model shows that thoughts about eating can directy lead to overeating by being, for example, related to craving or to eating control (3). These eating-related (disinhibitive) thoughts are assumed to temporarily release the obese person from his/her dieting rules and cause overeating (Polivy, 1976; Polivy \& Herman, 1985; but see: Jansen $\&$ van den Hout, 1991). An example of a disinhibitive cognition is "Whenever I start eating from those chocolates, I have to finish the whole bowl". Overeating, in its turn, is likely to activate cognitions about eating, weight and shape (4) [Fairburn et al., 1993; Fairburn et al., 2003), thereby closing the circle. Moreover, the overeating may activate negative schemes about the self (5) (Fairburn et al., 
1993). This again may close the circle as negative thoughts about the self are likely to activate thoughts about appearance and eating (6) (Meijboom, Jansen, Kampman, \& Schouten, 1999). According to our model, self-schemas might also be activated directly by situations that are unrelated to eating or appearance such as, for example, failing an exam. The model described above provides a rationale for the cognitive treatment. The content of the treatment will be described below.

\section{THE COGNITIVE TREATMENT}

The goal of the cognitive treatment is to change dysfunctional cognitions about eating, weight and shape and self-schemas. To identify and change these cognitions, techniques are used that were outlined by Beck (1976). The therapeutic relationship was based on empathy and understanding, and was characterized by a team appraach called "collaborative empiricism". This means that both the client and the therapist were engaged in the investigation of the client's thoughts. The Socratic method - in which questioning plays a central role - was used to identify and challenge the client's cognitions. To test the validity of their cognitions, clients were furthermore encouraged to set up behavioral experiments. Homework assignments played a central role during the therapy. Homework was assigned each session, and was marked by the therapist. A workbook was developed especially for the treatment. In this workbook, the treatment rationale was presented and explanations for each session were given. Furthermore, the workbook included the homework assignments and cognitive diaries. An important feature of the treatment was to teach clients to identify and challenge the cognitions themselves - with the help of their workbook and homework assignments - so they could continue practicing cognitive therapy by themselves after treatment ended. The cognitive treatment was provided in groups of up to twelve participants, guided by one cognitive behavioral therapist. Cognitive behavioral therapists were thoroughly trained into the treatment protocol by one of two therapists experienced in the cognitive treatment of obesity. The treatment consisted of ten weekly one-hour sessions.

In the first session, attention was paid to the clients' motivation for treatment. Weight loss experiences and future expectations were reviewed. From participants' past experiences with weight loss and weight gain it was concluded that it was important to focus on small but realistic weight losses that would be long-term maintainable. Furthermore, attention was paid to the role of a psychologist in the treatment of obesity and agreements were made concerning attendance, commitment, homework and privacy. The first homework assignment was to recall the goals of the cognitive treatment (with regard to realistic weight loss). In the second session, the rationale was explained to the clients. Guided by examples from the group, the cognitive model was put on a blackboard. The concepts that were relevant for a good understanding of the cognitive model (1.e., "situation", "thoughts", "emotions" and "behavior") were introduced and explained. Homework for the second session was to reread the treatment rationale and to 
practice with the new concepts by, for example, thinking of one's own preconceptions for dysfunctional thoughts) in general. In sessions 3 to 8 , dysfunctional cognitions about eating. weight and shape, and self-schemas, were identified and challenged. Cognitive diaries (for an example see Figure 4.2) were introduced and participants were encouraged to use these diaries at home to record personal critical situations and dysfunctional thoughts. They also scored the credibility of their dysfunctional thoughts $(0-100 \%)$. Furthermore, the validity of the dysfunctional thoughts was tested and alternative thoughts were generated. Guided by examples from the group, the group was acting as a research team, investigating the validity of dysfunctional cognitions and creating alternative and more realistic thoughts. The new thoughts were again scored on credibility $(0-100 \%)$. Methods used for testing the validity of a person's thoughts were the Socratic dialogue and behavioral experiments. Behavioral experiments (for an example see Figure 4.3) were set up during the session, carried out at home, and discussed in the next session. The final two sessions were concerned with the oncoming treatment ending. Dysfunctional thoughts regarding relapse were identified and challenged. Furthermore, participants were

Table 4.1: Brief presentation of the protocol

\section{Brief presentation of the protocol}

Session 1 Introduction of the therapist and the group members.

Agreements on attendance, commitment, homework and privacy

Discussing motivation for treatment setting realistic weight-loss goals

Homework recalling the goals with regard to weight loss

Session 2 Explaining the rationale of the cognitive treatment

Explaining relevant concepts (situation, thoughts, emotions, behavior)

Homework: reread treatment rationale and practice with the new concepts

Sessions 3-8xplaining and using the cognitive techniques (Socratic dialogue, behavioral experiments) Practicing the new concepts (situation, thoughts, emotions, behavior)

Introducing the cognitive diary

Identifying dysfunctional cognitions about eating, weight and shape, and self-schemas

Challenging dysfunctional cognitions about eating, weight and shape, and self-schemas

Setting up behavioral experiments

Homework: cognitive diaries and behavioral experiments

Sessions 9-10 Preparing for the oncoming treatment ending

Identifying and challenging dysfunctional cognitions about relapse

Preparing for difficult moments in the future

Stressing the importance of self-practicing cognitive therapy in the future with the help of the workbook 
prepared for difficult moments in the future. It was stressed that participants had learned skills to identify and challenge their own dysfunctional cognitions in the future. In Table 4.1, our treatment protocol is presented in brief.

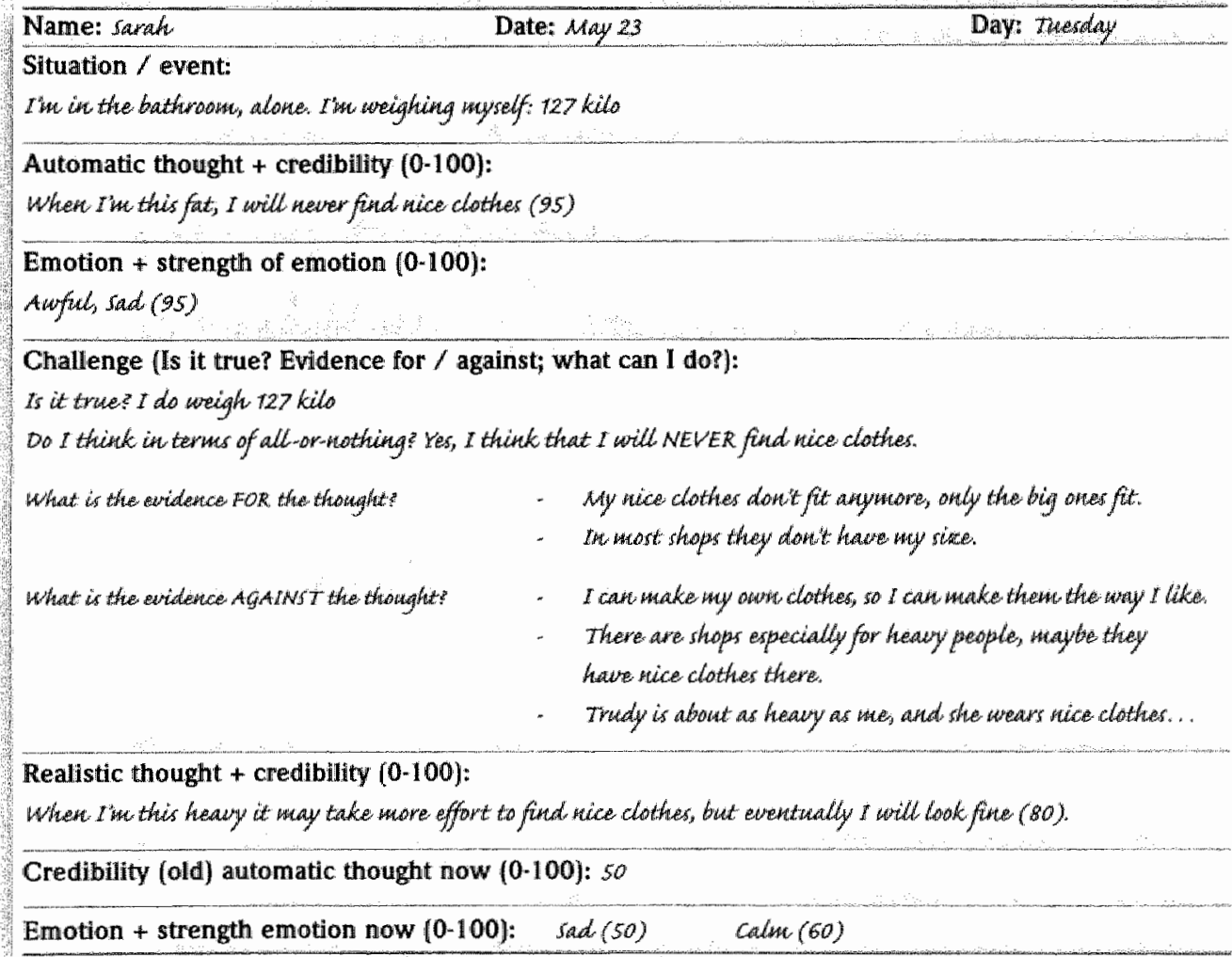

Figure 4.2: Example of a completed cognitive diary 


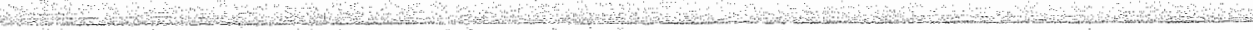

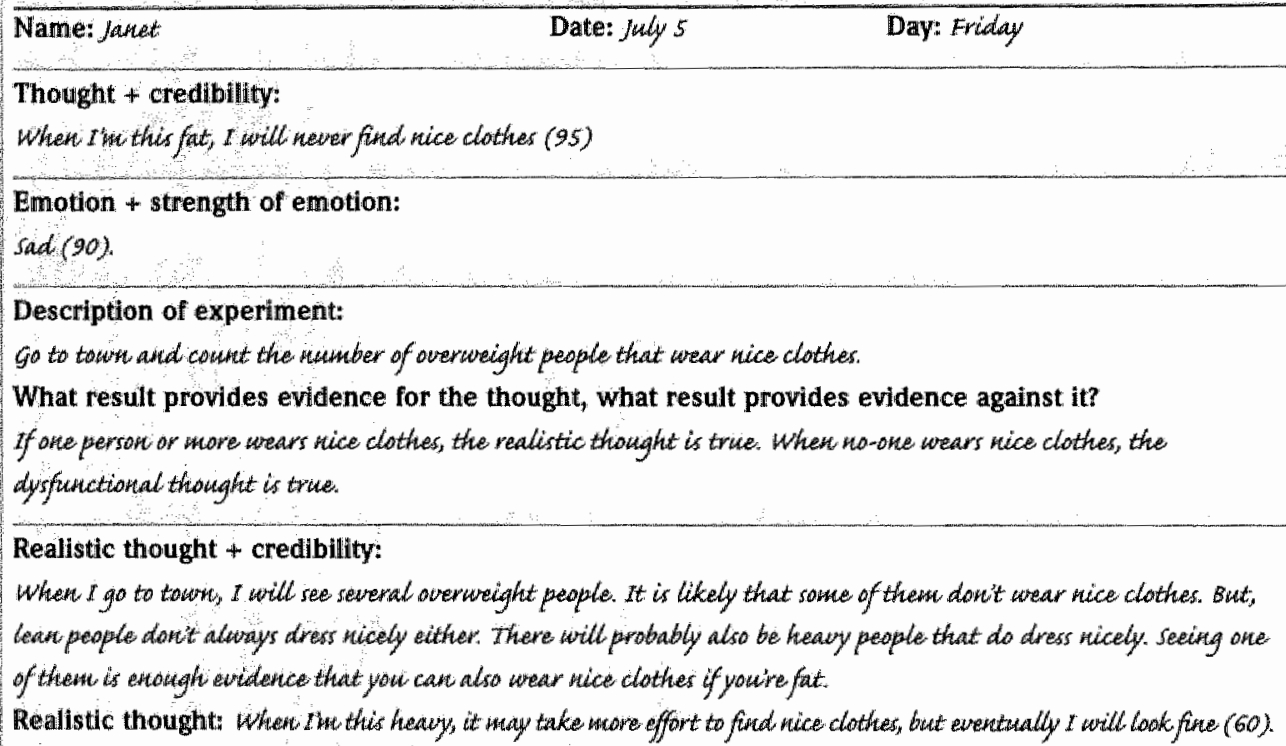

\section{What is the result of the experiment?}

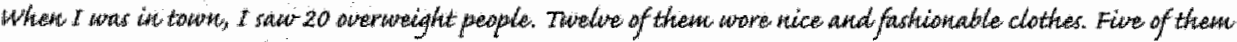

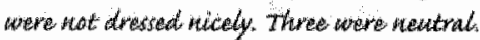

Credibility dysfunctional thought now: 40

Credibility realistlc thought now: so

Emotion and strength emotion now: Relicued, relaxed $(85)$

W.

Figure 4.3: Example of a behavioral experiment 


\section{CHAPTER 5}

CBT PREVENTS RELAPSE

IN OBESITY TREATMENT

WHEREAS STANDARD BEHAVIOR

THERAPY DOES NOT:

RESULTS FROM A RCT

Submitted for publication as: Werrij, M. Q., Mulkens, S., Elgersma, H., Ament, A., Hospers, H. J., \& Jansen, A. (2005). CBT prevents rellapse in obesity treatment whereas standard behavior therapy does not: results from a RCT. 


\section{Chapter 5}

\section{ABSTRACT}

The authors investigated the effectiveness of a cognitive-behavioral (CBT) and a standard behavioral (SBT) treatment for obesity. It was hypothesized that 1) CBT would be more effective in reducing shape, weight and eating concerns, binge eating, and depression, and in improving self-esteem than SBT, and 2) weight losses would be maintained better in the CBT. Participants $(n=204)$ were randomly assigned to treatment. One year follow-up results indicate that weight losses were maintained after CBT but not after SBT. Moreover, CBT was superior in the improvement of eating- and weight concerns in the intention-to-treat analyses. The effectiveness of CBT was even more prominent for participants with depressive symptoms. Adding cognitive therapy to the treatment for obesity improves its effectiveness. 
Obesity is a growing public health problem in Western countries (Visscher, Kromhout, \& Seidell, 2002). In the United States, about $20.25 \%$ of the adult population is considered obese (WHO, 1998), while in Europe 10-25\% is affected (Seidell \& Fiegal, 1997). The prevalence of obesity has recently increased in such a way that the World Health Organization even declared obesity a global epidemic (Wadden, Brownell, \& Foster, 2002; WHO, 1998). Moreover, obesity is related to several health problems, including cardiovascular diseases, diabetes and some cancers. On the psychological level - although evidence is not entirely unequivocal - obesity has been assaciated with a variety of problems such as concerns about appearance, binge eating; a depressed mood and low self-esteem le.g., Berman, Berman, Heymsfield, Fauci, \& Ackerman, 1992; Johnsen, Gorin, Stone, \& LeGrange, 2003; Musante, Costanzo, \& Friedman, 1998; Quinn \& Crocker, 1999; Stunkard \& Wadden, 1992; Wilfley, Schwartz, Spurrell, \& Fairburn, $2000)$. In the past 35 years, behavioral programs have been a standard treatment for obesity. These programs typically focus on weight loss through the reduction of energy intake and the stimulation of physical exercise. However, as many authors note, there are still some serious shortcomings to those programs (e.g., Garner \& Wooley, 1991; Jeffery et al., 2000; Wilson, 1994). A main problem concerns the ineffectiveness of behavioral programs in the long run. Follow-up studies have shown high relapse rates: after $1-5$ years most people regained their initially lost weight (e.g., Garner \& Wooley, 1991; Jeffery et al., 2000; Wilson, 1994). Attempts to lose regained weight, however, are mostly as unsuccessful in the long term as previous dieting attempts, thus resulting in cycles of losing and gaining weight.

Recently, cognitive behavioral programs have been developed to address this problem. These programs discourage radical dieting, hypothesizing that a treatment focused on lifestyle changes will be psychologically beneficial and might finally result in modest weight loss (Cooper \& Fairburn, 2001; Nauta, Hospers, Kok, \& Jansen, 2000; Polivy \& Herman, 1992; Sbrocco, Nedegaard, Stone, \& Lewis, 1999). Cognitive behavioral treatments, addressing both eating behavior and dysfunctional cognitions, were shown to be effective in reducing eating binges and in improving psychopathology in bulimia nervosa (e.g. Fairburn et al., 1991; Wilson \& Smith, 1987) and binge eating disorder (Agras et al., 1994; Agras, Telch, Arnow, Eldredge, \& Marnell, 1997; Nauta, Hospers, Kok, et al, 2000; Smith, Marcus, \& Kaye, 1992). Importantly, the effects of CBT in bulimia nervosa are usually well maintained le.g. Jansen, Elgersma, Nederkoorn, \& Smeets, 2002; Wilson, 1999).

A cognitive behavioral approach to the treatment of obesity was proposed by Cooper and Fairburn (2001). According to their experience, not health-related motives but rather a desire to change appearance is the primary reason for people to attempt to lose weight. However, weight is only one of the factors involved in changing one's appearance, and losing the desired amount of weight is very difficuit as people often set unrealistic goals (Foster, Wadden, Vogt, \& Brewer, 1997; Jeffery, Wing, \& Mayer, 19981. As a result, not reaching the (unrealistic) target weight leads to demoralization and giving up the dieting attempt. Therefore, the authors propose a new cognitive behavioral program, in which participants learn to accept and value 
the weight loss they have reached, to adopt weight stability as their goal and to use behavioral skills and cognitive responses required for successful weight control (Cooper \& Fairburn, 2001). Specifically, attention is paid to patients' concerns about appearance, aiming to enhance selfacceptance.

The efficacy of a purely cognitive and a purely behavioral group intervention for obese bingers and obese non-bingers was investigated by Nauta and colleagues (Nauta, Hospers, Kok, et al., 2000 . The cognitive treatment was more effective in reducing eating and appearance related concerns, binge eating and - only on the short term - in improving self-esteem than the behaviorai treatment. Short term weight loss was greater for participants in the behavioral treatment than for those in the cognitive treatment, but after six months bath groups had gained weight. Although both obese bingers and obese non-bingers benefited from the treatments, obese bingers generally improved more on weight, shape and eating concerns, self-esteem and depression than obese non-bingers (Nauta, Hospers, Kok, et al., 2000). These findings suggest that the use of cognitive techniques in the treatment for obese persons might improve current treatments, especially with respect to eating pathology and self-esteem. However, a limitation of the Nauta et al. study concerns the generalizability. Participants were recruited by advertisements that offered treatments for eating problems. Therefore, of all overweight persons seeking treatment only those who consider themselves as having eating problems might have been interested in participating. Whether cognitive techniques will be helpful in the treatment of a more general obese population remains to be investigated.

In sum, these studies suggest a focus of obesity treatment different from radicall dieting and purely weight loss. Instead, it is proposed that programs should aim to normalize eating behavior and reduce concerns about appearance. For overweight and obese people seeking help for their weight problems, dieticians are often the most obvious and best accessible health practitioners in the Netherlands. Regular dietary treatment by dieticians aims to change dietary patterns, and is not specifically directed at changing psychological characteristics. Extending these treatments with cognitive therapy might well improve the long-term effectiveness of these treatments. In the present study the effectiveness of a cognitive behavioral and a standard behavioral treatment for obesity was investigated within the clinical practice of dieticians. Both treatments aimed to produce long term maintainable weight losses of 5-10\% by changing dietary patterns. Furthermore, the cognitive behavioral treatment changed dysfunctional cognitions whereas the standard behavioral treatment used physical exercise. We hypothesized that participants in the experimental cognitive behavioral treatment would improve more on specific eating psychopathology (i.e., concerns about shape, weight and eating, and binge eating), depression and selfesteem than participants in the standard behavioral treatment. We expected these effects to be most pronounced in the long term (i.e., one year after treatment). Concerning $B M L$, we did not expect any differences between the treatment groups on the short term. In the long run, we hypothesized that participants in the cognitive behavioral treatment would maintain their weight losses better than participants in the standard behavioral treatment. 
Depression has been found to co-occur with a variety of disorders ffor a review see Mendlewicz, 1998), and also in overweight and obesity, depressive symptoms are often present le.g., Kalarchian, Wilson, Brolin, \& Bradley, 1998; Musante et al., 1998; Porzelius, Houston, Smith, Arfien, \& Fisher, 1995; Tanco, Linden, \& Earle, 1998 ; Troisi, Scucchi, San Martino, Montera, d'Amore, \& Moles, 2001; but see e.g., Porzelius et al., 1995; Sbrocco et al., 1999). A comorbid depression generally aggravates symptoms (Mendlewicz, 1998) and can affect treatment outcome in a negative way (e.g. Abramowitz \& Foa, 2000; Overbeek, Schruers, Vermetten, \& Griez, 20021. Adapting treatment to the depression status of a patient might improve its outcome (e.g., Charney, Parahekaris, \& Gill, 2001; Johnson \& Lydiard, 1998). In the present study, it was additionally investigated whether mildly to moderately depressed overweight and obese people in particular benefit from the cognitive treatment.

\section{METHODS}

\section{Participants}

Participants were recruited by advertisements in local newspapers offering a treatment for obesity, and registered for participation through the "Groene Kruis Zorg" [Green Cross Care] in Maastricht, an organization offering dietary treatments for obesity. Interested people were screened and checked for inclusion and exclusion criteria in a telephone interview. Inclusion criteria were $\mathrm{BMI}>27$ and age between 18 and 65 years. Exclusion criteria were pregnancy, current treatment for weight or psychological problems, no GP referral and not being able to exercise. Interested and eligible candidates received written information about the treatments, the inclusion and exclusion criteria were checked again, and an informed consent form was signed. The study was approved by the Maastricht University Medical Ethical Committee.

Participants were 204 overweight/obese men and women. Four people were excluded from the analyses because they had too many missing values $(>10 \%)$ on the pretreatment questionnaire. The final study sample thus consisted of 200 overweight and obese people. Of the 200 participants, $81 \%$ were female. Mean age was $45(S D=12)$ years, ranging from 19.65 years, and mean BMI was $33.4(S D=4.6)$. BMI ranged from 27.0-52.3.

\section{Procedure and randomization}

Treatments were carried out in Maastricht and its neighboring villages between March 2001 and December 2002. Participants were randomly assigned to one of two treatment conditions; a cognitive behavioral group treatment (CBT) or a standard behavioral group treatment (SBT). For practical reasons, people could indicate their preferred day of the week, and they were scheduled to go to a treatment location in their neighborhood. Participants, nor Green Cross Care secretaries, nor dieticians were aware of the type of treatment (SBT or CBT) that was scheduled on each particular location. Ten days prior to the start of treatment participants 
received a pretreatment questionnaire that was handed in at the first treatment session. Four weeks after the last treatment session, posttreatment questionnaires were completed at home and returned by mail. Weight and height were measured each session. Follow-up measurements took place at the university one year after treatment. Home visits were done if a participant was unable to attend the follow-up meeting. In case no follow-up date could be arranged, the questionnaires were sent by mail.

\section{Treatments}

The cognitive behavioral treatment (CBT) and the standard behavioral treatment (SBT) had the same goal: achieving a small but long term maintainable weight loss $(5-10 \%)$. Both treatments were protocollized and consisted of ten weekly sessions of two hours each. They were provided in groups with a maximum of twelve participants. Each treatment session was divided in two parts. The first part (the first hour) was similar for both treatments and was carried out by dieticians. Aims of this first part were to change unhealthy dietary patterns into more healthy ones. To achieve this, realistic goals were set, information about dietary fat was provided, participants were instructed to monitor their diets by a food diary, and cooking classes were given to learn healthy cooking. Furthermore dietary patterns were changed trough a stepwise program, paying attention to eating three meals a day, eating at a regular place, not being distracted during meals, eating slowly and consciously, when to stop eating, how to refuse food, finding social support, going to a supermarket, and how to deal with parties. Participants received guidelines for a healthy diet but not a prescribed diet. Interventions in the second part (the second hour) of the treatment differed between the treatments; the CBT used cognitive restructuring whereas the SBT used physical exercise.

Cognitive Behavioral Treatment (CBT). Aims of the cognitive hour were to change dysfunctional cognitions concerning eating, weight and shape, and self-schemas. To achieve this, automatic cognitions were identified and challenged, and behavioral experiments were sel up (Beck, 1976). Participants were provided with a workbook containing background information about the cognitive sessions and homework assignments. Each session, homework - including thought diaries - was assigned and marked by the therapist. In the first two treatment sessions, expectancies concerning weight loss were discussed, reasonable goals were set, and the treatment rationale was explained by the therapist. In the next six sessions, cognitions concerning weight, shape and eating and self-schemas were identified and challenged. In the final two sessions, participants were prepared for the oncoming treatment ending. CBT therapists were thoroughly trained into the experimental program by one of two CBT therapists experienced in the cognitive treatment of eating disorders and obesity (S.M. and H. E.), and attended weekly one-hour supervision sessions. Furthermore, to ensure therapist's compliance to the protocal, ali session were audiotaped.

Standard Behavioral Treatment (SBT). In the second hour of treatment, the SBT group engaged in a low intensity exercising program superwised by a physiotherapist. Aim of this 
exercising program was to motivate participants for physical exercising. The combination of diet management (1 hour) and physical exercise ( 1 hour) in groups is the local standard treatment for obesity, given by dieticians.

\section{Measures}

Eating psychopathology. Specific eating psychopathology was measured with the Eating Disorder Examination - Questionnaire (EDEQ; Fairburn \& Beglin, 1994), a 36 item questionnaire that measures concerns about shape, weight and eating, restraint and binge eating. Subscale scores for shape, weight and eating concerns and restraint range between 0-6. A higher score indicates more severe eating psychopathology.

Binge eating and $B E D$. The frequency of binge eating (i.e., the number of binges per 28 days) was additionally measured by a self composed questionnaire. Because eating binges can not be measured reliably by the EDEO (Fairburn \& Beglin, 1994; Kalarchian et al., 2000; Wilfley, Schwartz, Spurrell \& Fairburn, 1997) this questionnaire tested the occurrence of eating binges by open ended questions investigating the situation and the content of the potential binges. Furthermore, participants' emotions and feelings of control during the potential binges were investigated. The amount of food that was eaten was defined as an eating binge when 1 ) it was larger than most people would eat during a similar period of time and under similar circumstances, and 2] a sense of lack of control over eating during the episode was experienced. Participants were diagnosed with binge eating disorder (BED) if they had eating binges twice a week or more (DSM-IV; APA, 1994).

Depression. Depressive symptomatology was measured by the 21-item Beck Depression Inventory (BDI; Beck, Ward, Mendelson, Mock, \& Erbaugh, 1961). The BDI measures severity of depressive symptomatology. Items are scored on a 4-point scale. One item about weight loss was excluded from analyses and the sum of the remaining 20 items was calculated. A higher score indicates a more severe depression. Scores below ten are normal, a score of ten or more indicates mild to moderate depression (Beck, Steer, \& Garbin, 1988).

Selfesteem. Self-Esteem was measured by the Rosenberg Self-Esteem Scale (RSE; Rosenberg, 1965). The RSE is a 10-1tem questionnaire that measures global selfesteem. Items are scored on a 4-point scale. A higher score indicates a more positive self-esteem. Scores below 21 indicate low self-esteem (Rosenberg, 19791.

BMI. Weight and length were measured in street clothes, without shoes. Body Mass Index (BMJ: weight $(\mathrm{kg}) /$ height $(\mathrm{m})^{2}$ ) was calculated.

Cognitions. Eleven dysfunctional cognitions (e.g., "If I am fat I can not dress nicely"), derived from cognitions reported in previous research (Nauta, Hospers, Jansen, \& Kok, 2000; Nauta, Hospers, Kok, et al., 2000), were scored on credibility ( $1=$ very incredible $-5=$ very credible). Reliability analyses showed that one item did not fit well into the scale. The remaining ten items were averaged to form the cognition scale. This scale based on the ten items had a good reliability ( $\alpha=88)$.

Suitability of treatment. The suitability of the treatments was scored on a nine-point scale 
$1=$ not at all suitable, $9=$ extremely suitable) at sessions 2 and 10 by three questions ("How suitable do you think the treatment is for you", "How many faith do you have in the treatment" and "Would you recommend the treatment to an overweight friend"). The suitability scale that was based on these three items had a good reliability $(\alpha=.83)$.

\section{Statistical analyses}

A missing value analysis was performed to replace missing data. For each participant, the total number of missing values for the three questionnaires (EDEQ, BDI, RSE) was calculated. A total of less than $10 \%$ missing values was accepted for the analyses. In these cases $(n=200)$, missing item scores were replaced by the mean score on the remaining items of the particular questionnaire (EDEO, BDI or RSE).

Pretreatment differences between the participants in the two treatment conditions /CBT and SBT) on demographic variables (age, gender) and the main outcome measures (EDEO, binge eating, BDI, RSE, BMI) were investigated by chi-square analyses (gender) and independent samples ttest (age and outcome measures). Differences between treatment dropouts and completers were also studied by independent samples $t$ test. To investigate whether demographic wariables or outcome measures influenced treatment dropout, a logistic regression analysis with treatment dropout as the dependent variable was performed. In this analysis, binge eating was added as a dichotomous variable ( 0 = non-binger, $1=$ binger $)$.

Primary analyses were by intention to treat. In case of missing data the last available data were carried forward. All anajyses were performed on the main outcome measures (EDEO restraint, EDEQ eating concerns, EDEQ weight concerns, EDEQ shape concerns, EDEQ global score, binge eating frequency, BDI, RSE, BMI and on cognitions. Binge eating frequency was additionally analyzed for bingers only. The results were analyzed in two steps. First, 2 (group: CBT vs SBT) x 3 (time: pretreatment vs posttreatment vs one year follow-up) repeated measures ANOVA's were performed to study time trend differences between the treatment conditions. In the results section, these analyses will be referred to as "time trends over the three measurements". Second, planned comparisons were conducted to study changes between pretreatment and posttreatment (called "treatment effectiveness" in the resuits section) and between posttreatment and follow-up (called "maintenance or relapse" in the results section). To study treatment effectiveness, 2 (group: CBT vs SBT) $\times 2$ (time: pretreatment vs posttreatment) repeated measures ANOVA's were performed. To study whether treatment results were maintained one year after treatment, 2 (group: CBT vS SBT) x 2 (tume: posttreatment vs one year followup) repeated measures ANOVA's were carried out. For significant interactions, paired samples ttest were conducted within each group. For the ANOVA's, partial eta squared is reported as a measure of effect size; for the paired samples ttests, Cohen's d is reported (Cohen, 1992).

Secondary analyses were performed on complete cases $(n=119)$. Complete cases were participants who completed treatment and returned both the posttreatment and the follow-up questionnaire. Treatment completion was defined by attending at least six treatment sessions. 
Following these criteria, there were 158 treatment completers $(79 \%)$. Of the 158 completers, 119 filled in all questionnaires ( $60 \%$ of the total sample). Analyses were similar to the intention. to-treat analyses.

To investigate the effectiveness of $\mathrm{CBT}$ and $\mathrm{SBT}$ for mildy to moderately depressed participants, the primary and secondary analyses were additionally conducted within the subgroup of participants who scored ten or more on the BDI (Beck, Steer \& Garbin, 1988). This subgroup will be referred to as the symptomatic subgroup. In the total sample, 83 people scored ten or more on the BDI (CBT: $n=43$, SBT: $n=40$ ]. Within the symptomatic subgroup, there were 45 complete cases (CBT: $n=25$, SBT: $n=20$ ).

\section{RESULTS}

\section{Pretreatment characteristics and treatment suitability}

In the CBT, $84 \%$ of the participants were female. Mean age was 44 years ( $S D=11.9)$. In the $\mathrm{SBT}, 78 \%$ of the participants were female. Mean age was 45 years $(S D=12.2)$. At the pretreatment measurement, participants in the CBT and in the SBT did not differ on age, gender, EDEQ restraint, EDEQ eating concerns, binge eating, BDI and BMl (all p-values $>.19$ ). In each treatment group, eight participants were classified as BED patients. Pretreatment differences between participants in the two treatments emerged for EDEQ weight concerns, $t(198)=2.69$, $p<.01$, shape concerns, $t(198)=2.51, p<.02$ and global score, $t(198)=2.38, p<.02$ and for self-esteem, $t(198)=2.74, p<.01$. Participants in the CBT scored higher on weight concerns, shape concerns and EDEO global score than participants in the SBT. Furthermore, participants in the CBT had lower self-esteem than those in the SBT. For pretreatment means on the outcome measures, see Table 5.1.

At session 2, participants in the SBT gave higher treatment suitability ratings than participants in the CBT, $t(185),=2.9, p<.01$. Inspection of the means, however, reveals that both treatments were considered suitable (CBT: $M=6.8, \mathrm{SBT}: M=7.4)$. At session 10, treatment suitability was still believed to be higher in the SBT, $t[161]=2.2, p<.03$ (CBT: $M=6.6$, SBT: $M=7.3$ ).

\section{Dropout analysis}

Participants who attended five sessions or less were considered treatment dropouts. Despite all effort that was made to encourage participants to attend all treatment sessions, 42 people $(21 \%)$ dropped out of treatment. Treatment dropouts were characterized by higher pretreatment scores on weight concerns, $t(198)=2.1, p<.04$, shape concerns, $t(198)=2.0, p<.05$, EDEQ global score, $t(198)=2.2, p<.03$ and depressive symptoms, $t(198)=2.2, p<.03$. Moreover, there tended to be more treatment dropout in the SBT (26\%) than in the CBT ( $16 \%$ ), $\chi^{2}(1)=3.2, p<.08$. The logistic regression showed that dropout was predicted by (higher) 


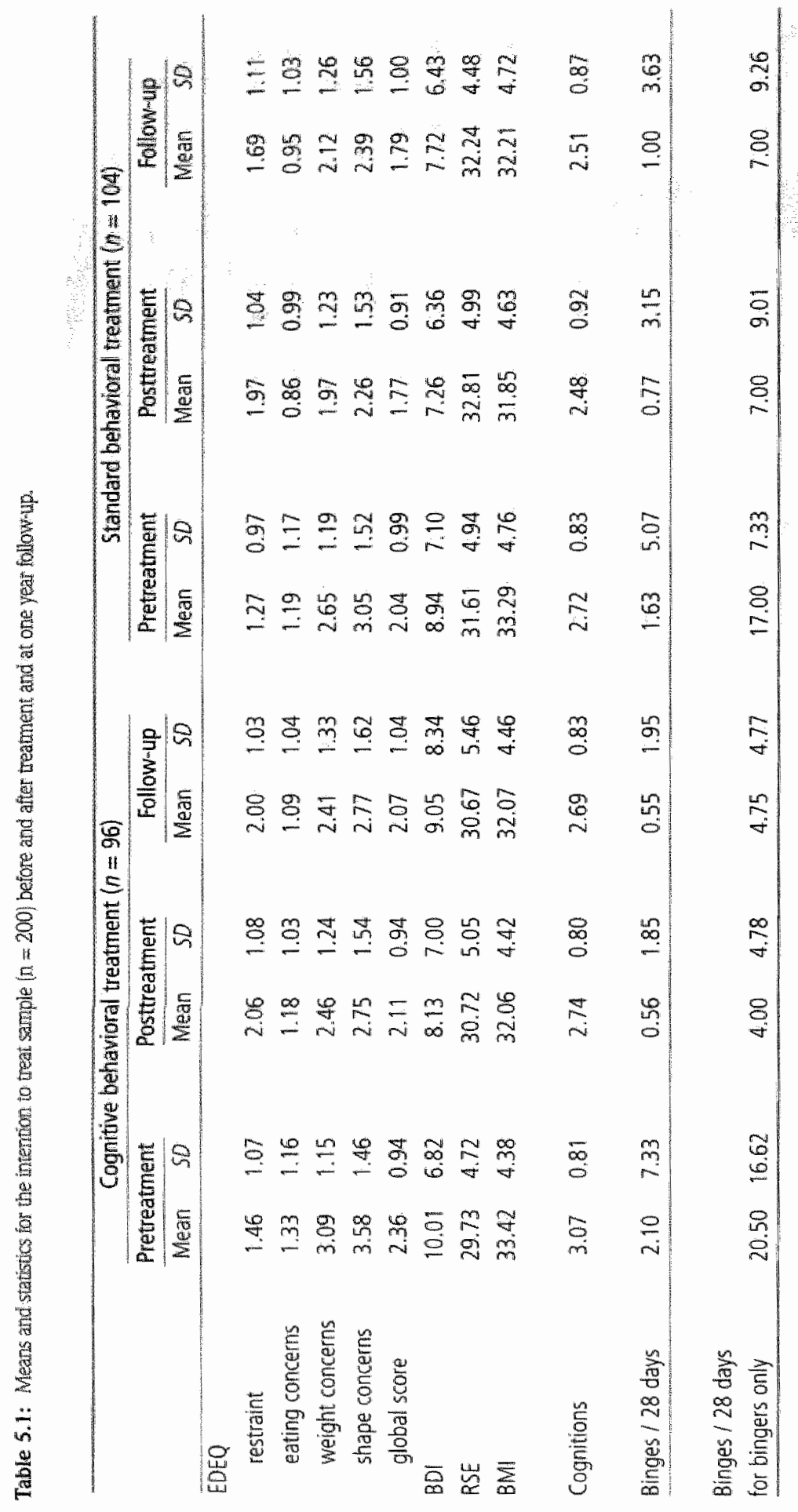




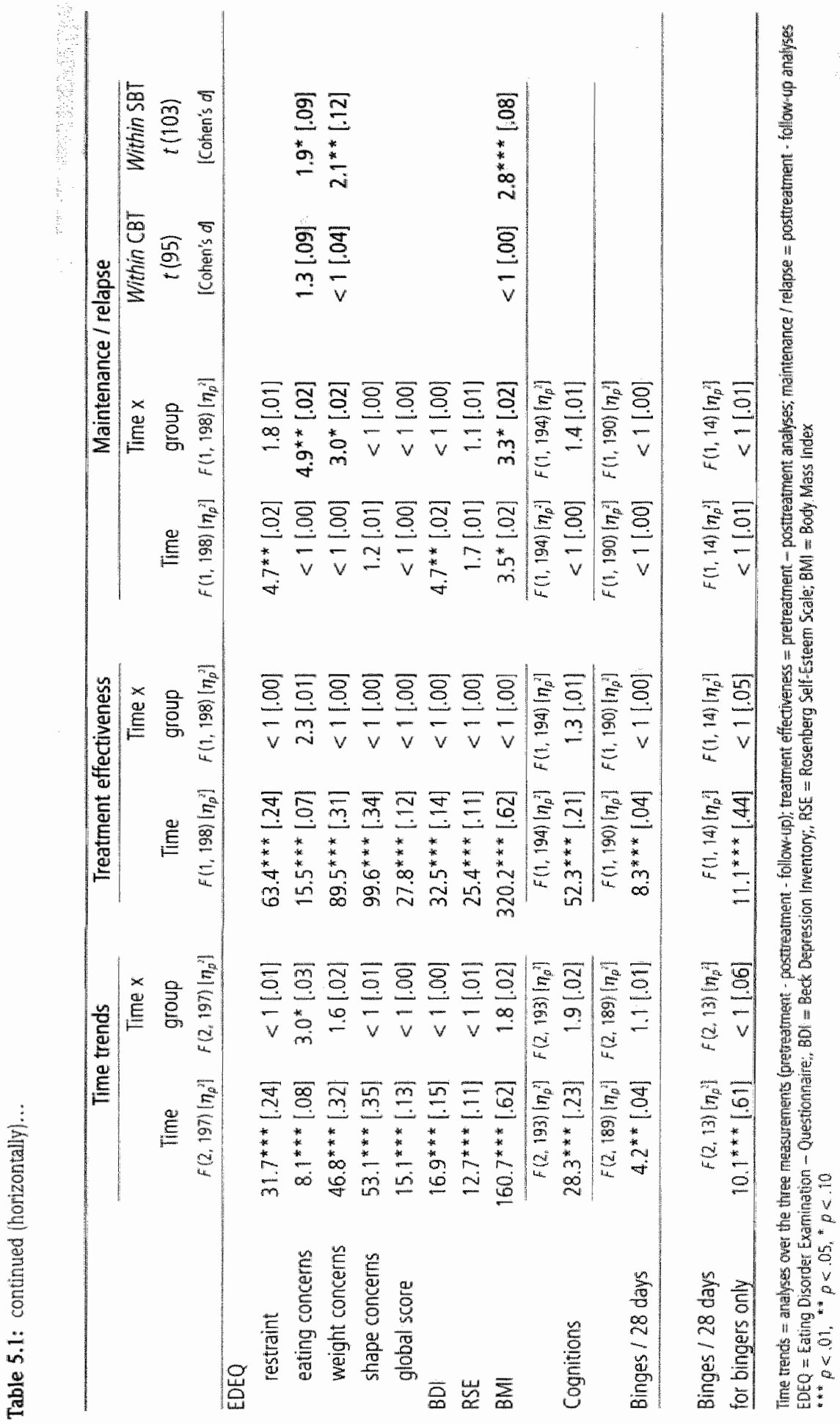


pretreatment EDEO global scores $(b=0.52, p<.01)$ and by treatment $(b=0.86, p<.03)$. The chance of dropping out of treatment was greater in the SBT.

\section{Intention to treat analyses.}

For the mean scores and the results of the statistic tests see Table 5.1.

Time trends over the three measurements. Main effects of time were found for EDEO restraint, EDEQ weight concerns, EDEQ shape concerns, EDEO global score, binge eating, RSE, $B M]$, and cognitions, showing that these factors changed over time. The time $x$ group interactions were not significant for these measures, indicating that the time trends did not differ between CBT and SBT. For EDEQ eating concerns, a significant main effect of time was superseded by a marginally significant the time $x$ group interaction, indicating that the time trends for eating concerns tended to differ between the treatments. Within bingers, binge eating frequency also changed over time. The time $x$ group interaction was not significant, indicating that there were no differences between the treatments.

Treatment effectiveness. After treatment, participants scored higher on restraint, were less concerned about eating, weight and shape, scored lower on the EDEQ global score, had less eating binges, less depressive symptoms, more self-esteem, a lower BMI and less dysfunctional cognitions than before treatment. These results emerged from significant main effects of time for EDEO restraint, EDEQ eating concerns, EDEQ weight concerns, EDEQ shape concerns, EDEQ global score, binge eating, BDI, RSE, BMI and cognitions. There were no differences in time effects between the CBT and SBT; none of the time $\mathrm{x}$ group interactions were significant. For bingers, binge eating frequency also decreased after treatment, as became clear from a significant main effect of time. The time $x$ group interaction was not significant, indicating that there was no difference between the treatments.

Maintenance or relapse? For EDEO shape concerns, EDEQ global score, binge eating, RSE and cognitions, the results of treatment were maintained; the main effects of time nor the time $x$ group interactions were significant for these measures. For restraint and depressive symptoms however; a relapse in the direction of pretreatment levels was apparent, as emerged from significant main effects of time for EDEQ restraint and BDI. No time $\mathrm{x}$ group interactions were found for these measures, indicating that this pattern of relapse was similar for the CBT and the SBT. For concerns about eating and weight as well as for BMI, the results of both treatments differed. The time $x$ group interaction was significant for EDEQ eating concerns and marginally significant for EDEQ weight concerns. Unpacking these interactions by paired samples ttests shows that between posttreatment and follow up, both eating concerns and weight concerns did not change in the CBT but they tended to increase/increased in the SBT. For BMI a marginally significant main effect of time was superseded by a marginally significant time X group interaction. Paired samples ttests for each treatment condition showed that weight loss was maintained after CBT, but not after $5 B T$. Within bingers, the results for binge eating were also maintained; the main effect of time nor the time $\mathrm{x}$ group interaction were significant. 


\section{Complete cases analyses.}

For the mean scores and the results of the statistic tests see Table 5.2.

Time trends over the three measurements. Results of the complete cases analyses were similar to those of the analyses by intention to treat, except for eating concerns. Over time, mean scores on all outcome measures had changed, as became clear from significant main effects of time for EDEO restraint, EDEQ eating concerns, EDEO weight concerns, EDEO shape concerns, EDEQ global score, BDI, RSE, BMI' and cognitions. For binge eating, the main effect of time was marginally significant. None of the interactions between group and time were significant, indicating that the time trends did not differ between the treatment conditions, whereas in the intention to treat analyses, the time $\mathrm{x}$ group interaction was marginally significant for eating concerns. Within bingers - as in the intention to treat analysis - the main effect of time was significant while the time $x$ group interaction was not.

Treatment effectiveness. Again, intention to treat analyses and complete cases analyses revealed similar results. After treatment, complete cases scored higher on restraint, were less concerned about eating, weight and shape, scored lower on the EDEO global score, had less eating binges, were less depressed, had more self-esteem, had a lower BMI and less dysfunctional cognitions than before treatment. These results emerged from significant main effects of time for EDEQ restraint, EDEQ eating concerns, EDEQ weight concerns, EDEQ shape concerns, EDEO global score, binge eating, $\mathrm{BDI}_{\text {, }} \mathrm{RSE}, \mathrm{BMI}^{3}$, and cognitions. There were no differences in time effects between the CBT and SBT; none of the interactions between group and time were significant. Within bingers, binge eating frequency also decreased after treatment; the main effect of time was significant, the time $\mathrm{x}$ group interaction was not.

Maintenance or relapse? For restraint, EDEQ global score, binge eating "depressive symptoms, self-esteem, BMI, and cognitions, the results of the complete cases analyses were similar to those of the intention to treat analyses. For the EDEQ global score, RSE, cognitions and binge eating, no main effects of time or time $x$ group interactions emerged, meaning that the effects of treatment were maintained. For EDEO restraint and BDI, main effects of time were found, indicating that restraint scores decreased and depressive symploms increased between posttreatment and follow-up. There were no differences between the treatments for" these measures (no time x group interactions). For BMI, a significant main effect of time was superseded by a marginally significant ${ }^{5}$ interaction between group and time. Paired samples $t$ tests

1. Data are only reponted for those completers who filled out cuestioniaires at pretreatment, postreatment and one vear follow-up th = 119 . Of this group, BMil data were avanable of 115 completers; four completers did not provide weight data at one year follow-up. However, somere of the completers that did not seturn one at the questionnaires, did provide weight data at follow- up in = 15 , Analyses on BMI for the 130 completers that provided weight data did not lead to different festits.

2. Analyses on BAal for the 130 completers that prowided weight data (see footmote 1) revealed a manginally sionificant ume $x$ group interaction, indirating that time trends tiended to be different between CBT and SBT.

3. Anatyses on BMI for the 130 completers that provided weight data (see footmote 1) did not lead to different results

4. Analyses on But for the 130 completers that provided weight data hee footncte 1) did not lead to diffefent resthts.

5. Analyses on wat for the 130 completers that provided weight data (see footrote 1) showed that now both uhe main effect of tinge and the time $x$ grousp interaction were significant. 
Chapter 5

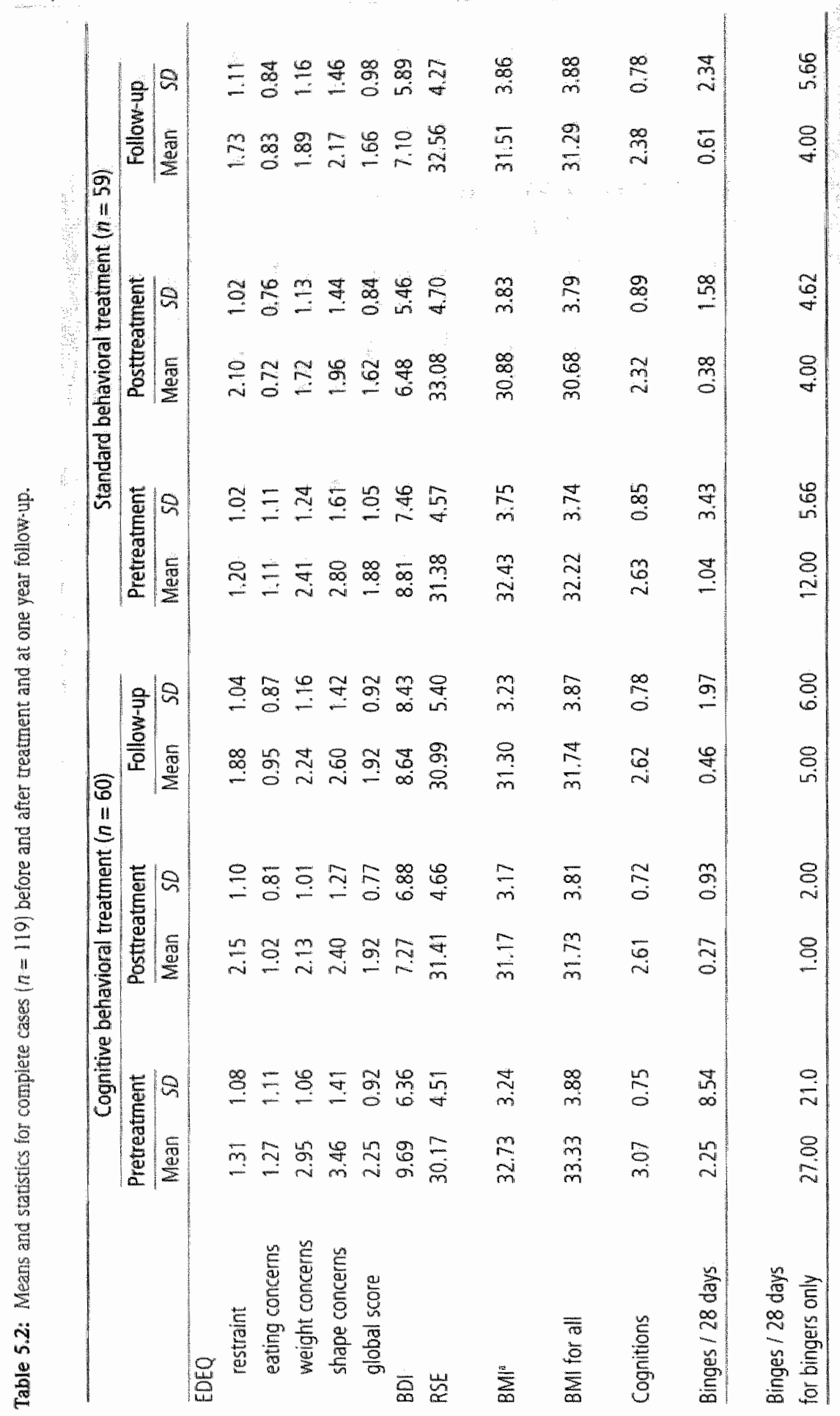


CBT for obesity

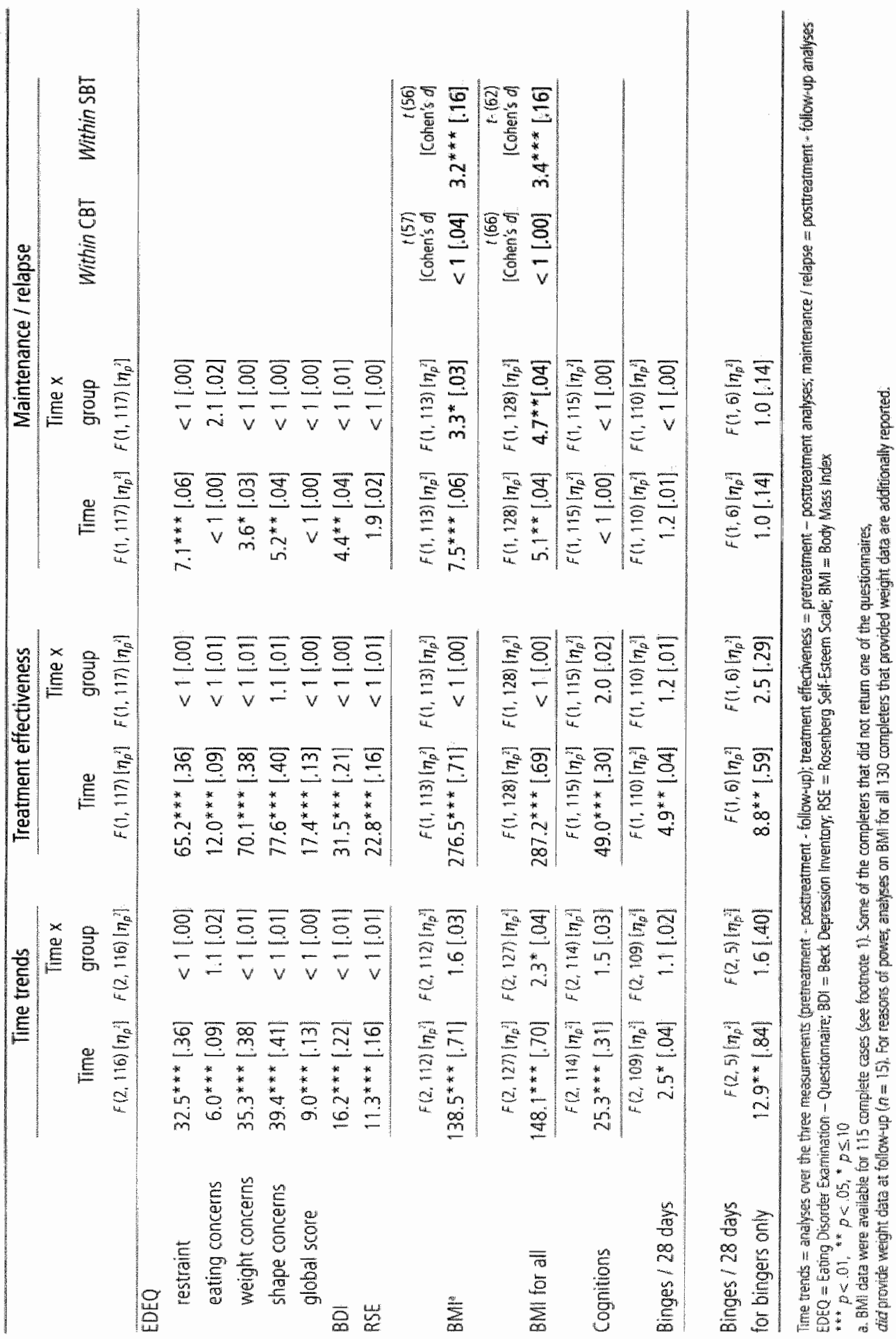




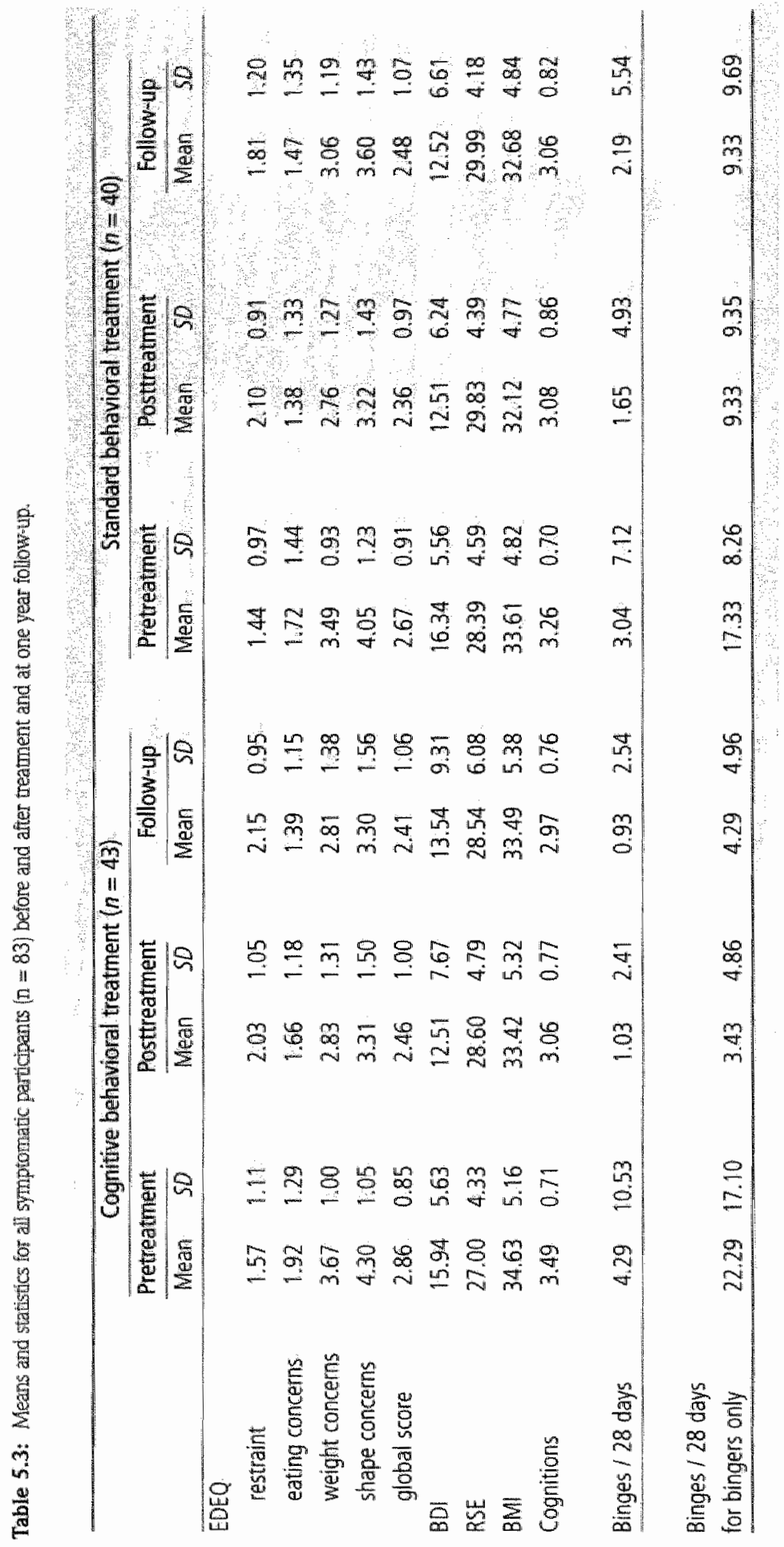




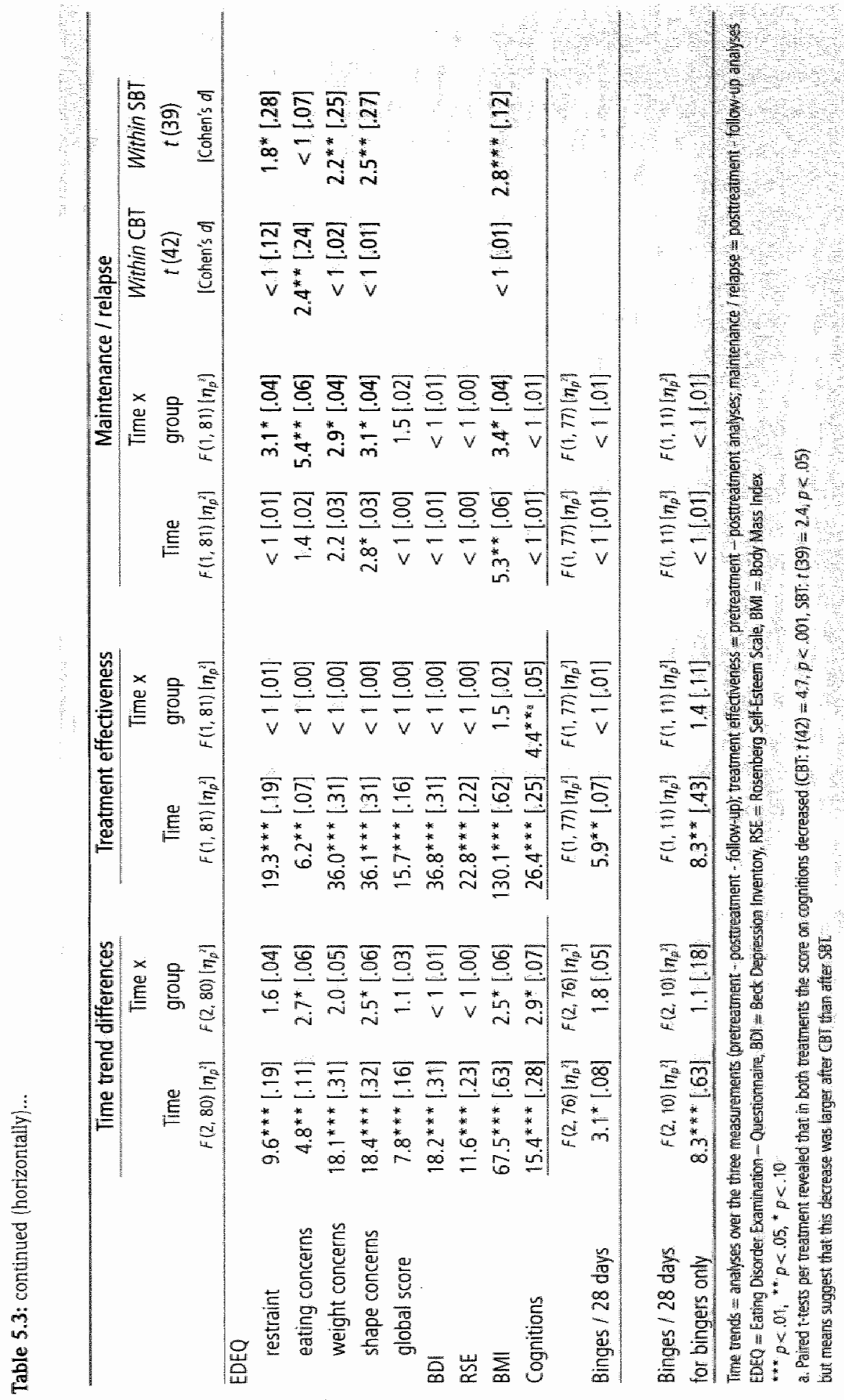


for the treatment conditions separately showed that weight loss was maintained in the CBT but not in the SBT condition. For concerns about eating, weight and shape, the complete cases analyses diverged from the intention to treat analyses. For eating concerns, there was no main effect of time and no time $x$ group interaction, indicating maintenance of treatment results. For concerns about weight and shape, however, a relapse in the direction of pretreatment levels was shown; main effects of time were significant for EDEQ shape concerns and marginally significant for EDEQ weight concerns. Time $\mathrm{X}$ group interactions were not significant for these measures, indicating that this pattern of relapse was similar for the CBT and SBT groups. Recall however, that intention to treat analyses revealed maintenance for shape concerns and superiority of the CBT for concerns about eating and weight. Within bingers, the results for binge eating were also maintained. Like in the intention to treat analyses, the main effect of time nor the time $x$ group interaction were significant.

\section{Treatment effects for the symptomatic subgroup - intention to treat analyses}

For the mean scores and the results of the statistic tests see Table 5.3.

Time trends over the three measurements. Within the study sample, 83 people /CBT: $n=43$, SBT: $n=40$ ) scored ten or more on the $\mathrm{BDI}$ and were defined as the symptomatic subgroup. Within the symptomatic subgroup, main effects of time were found for restraint, weight concerns, EDEQ global score, depressive symptoms and selfesteem, indicating that these factors changed over time. For binge eating, the main effect of time was marginally significant. The time $\mathrm{x}$ group interactions were not significant for these measures, indicating that for SBT and CBT these effects were the same. For eating concerns, shape concerns, BMI and cognitions, intention to treat analyses revealed significant main effects of time that were superseded by marginally significant time $\mathrm{X}$ group interactions. These results suggest that time effects tended to be different for the CBT and SBT. Planned comparisons (described below! will provide further inside into the nature of these differences. Within bingers, there was just a main effect of time, showing that binge eating frequency changed through the course of this study.

Treatment effectiveness. After treatment, symptomatic participants scored higher on restraint, were less concerned about eating, weight and shape, had less eating binges, less depressive symptoms, a higher self-esteem and a lower BMI than before treatment. These results emerged from significant main effects of time for these measures. There were no differences between the treatments (no time $\mathrm{x}$ group interactions). For cognitions, the time $\mathrm{x}$ group interaction was significant, indicating that for symptomatic participants, cognitions changed more after CBT than after SBT. For symptomatic bingers, binge eating frequency decreased after treatment, without any differences between the treatments. This was shown by a significant main effect of time. The time $x$ group interaction was not significant.

Maintenance or relapse? For EDEO global score, binge eating, depressive symptoms, selfesteem and cognitions, the results of treatment were maintained; the main effects of time nor 
the time $x$ group interactions were significant. For eating concerns, the time $x$ group interaction was significant. Whereas the results of treatment were maintained for participants in the SBT, eating concerns further decreased for participants in the CBT. For restraint and concerns about weight and shape, the time $\mathrm{x}$ group interactions were marginally significant. For SBT participants, restraint scores tended to decrease, whereas weight and shape concerns increased. For CBT participants, these factors remained the same. For BMI, the time $\mathrm{x}$ group interaction was marginally significant, suggesting that BMI increased for the SBT and remained the same for CBT participants. Within bingers, the results for binge eating were also maintained; the main effect of time nor the time $\mathrm{x}$ group interaction were significant.

\section{Treatment effects for the symptomatic subgroup - complete cases}

For the mean scores and the results of the statistic tests see Table 5.4.

Time trends over the three measurements. Within the symptomatic subgroup $(n=83)$, there were 45 complete cases (CBT: $n=25$, SBT: $n=20$ ). For restraint, weight concerns, EDEQ global score, depressive symptoms and self-esteem, the complete cases analyses were similar to the intention to treat analyses in that there were just main effects of time, indicating that these measures changed during the course of the study. For BMI - as in the intention to treat analyses - a main effect of time was superseded by a marginally significant time $\mathrm{x}$ group interaction, suggesting that time effects were different for CBT and SBT. For eating concerns, shape concerns, binge eating and cognitions, the results of the complete cases analyses diverged. For eating concerns, shape concerns and cognitions, just main effects of time were found - whereas intention to treat analyses revealed marginally significant time $\mathrm{x}$ group interactions probably due to reduced power. For binge eating, the main effect of time now failed to reach significance. Within bingers, however, the main effect of time was still significant.

Treatment effectiveness. The results of the complete cases analyses were similar to those of the intention to treat analyses, except for cognitions. Directly after treatment, symptomatic complete cases scored higher on restraint, were less concerned about eating, weight and shape, scored lower on the EDEO global score, had less depressive symptoms, a higher self-esteem, and a lower BMI. Binge eating frequency tended to decrease. These results emerged from significant main effects of time on these measures (the main effect for binge eating was marginally significant). None of the interactions between group and time were significant, suggesting that the effects of treatment were the same for CBT and SBT. Fol: cognitions, complete cases analyses revealed just a main effect of time, indicating that dysfunctional cognitions decreased equally well in both treatments. Intention to treat analyses, howewer, showed superiority of the CBT in reducing dysfunctional cognitions. For bingers, the main effect of time was marginally significant in the complete cases analyses while in the intention to treat analyses, it was significant.

Maintenance or relapse? For eating concerns, EDEQ global score, binge eating, depressive symptoms, self-esteem, BMI and cognitions, the results of the complete cases analyses were 


\section{Chapter 5}

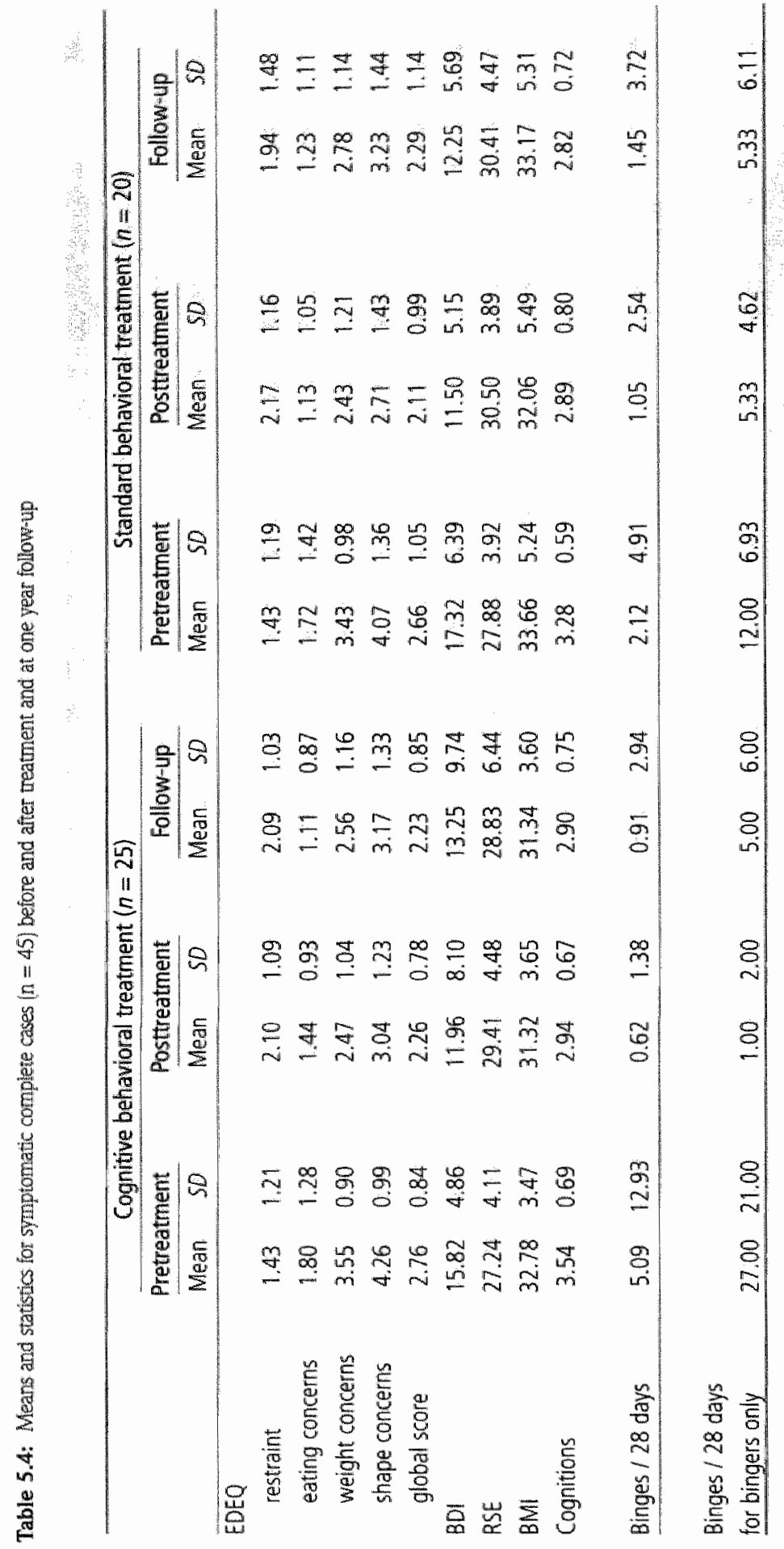




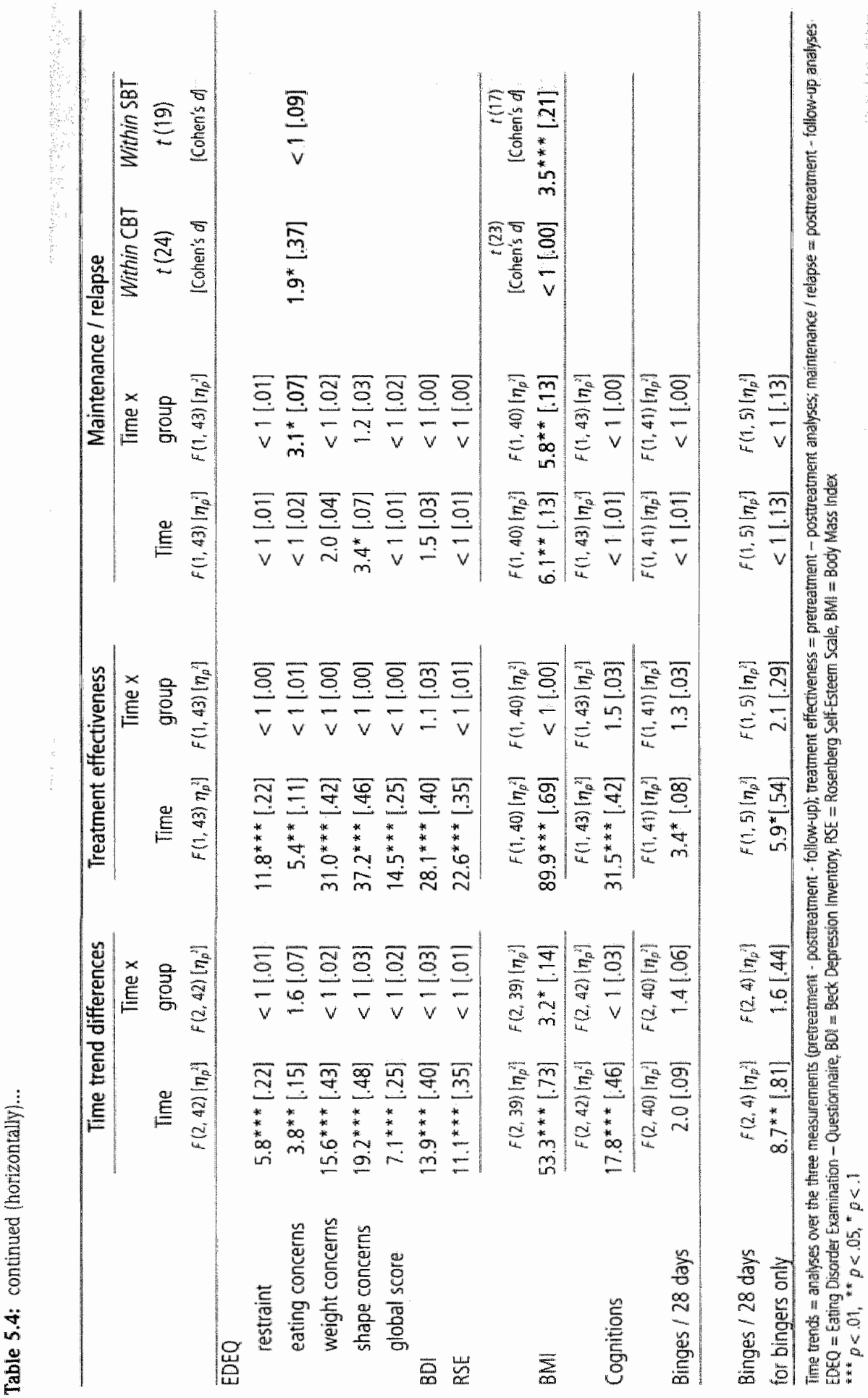


similar to those of the intention to treat analyses. For EDEO global score, binge eating, depressive symptoms, self-esteem and cognitions, the results of the treatment were maintained. The main effects of time nor the time $x$ group interactions were significant for these measures. For eating concerns, the time $x$ group interaction was marginally significant. Paired samples ttests within SBT and CBT showed that after SBT, the effects of treatment were maintained, whereas after

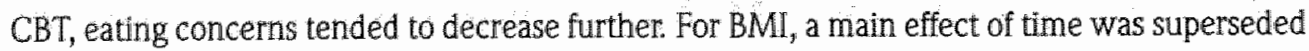
by a time $\mathrm{x}$ group interaction. Paired samples tests for the SBT and CBT separately indicate that weight loss was maintained for participants in the CBT but not for those in the SBT. For restraint and concerns about weight and shape, the results of the complete cases analyses diverged from those of the intention to treat analyses. For EDEQ restraint and EDEO weight concerns, the effects of treatment were maintained. The main effects of time nor the time $x$ group interactions were significant. Concerns about shape tended to increase between postreatment and follow-up as was suggested by a marginally significant main effect of time on EDEO shape concerns. The interaction between time and group was not significant, suggesting that this relapse was independent from treatment condition. Intention to treat analyses, however, revealed marginally significant time $\mathrm{X}$ group interactions for restraint and concerns about weight and shape, suggesting maintenance after CBT but not after SBT. Within bingers the results of the complete cases analyses were similar to those of the intention to treat analyses in that for binge eating, the results of treatment were maintained.

\section{Discussion}

The present study investigated the effectiveness of a cognitive behavioral and a standard behavioral treatment for obesity on specific eating psychopathology, depressive symptomatology, self-esteem and BMI. Both treatments aimed to produce long term maintainable weight loss. The one year follow-up results of this study show that - as hypothesized - CBT was successful in achieving this goal, whereas SBT was not. Whereas participants who received CBT maintained their weight loss, participants who received the standard treatment regained part of their weight. Superiority of the CBT also emerged for concerns about eating and weight in the analyses by intention to treat. For shape concerns, binge eating, depressive symptoms, self. esteem and cognitions, both treatments were equally successful. Surprisingly, cognitive therapy did not have additional benefits for these measures.

This finding that a cognitive (behavioral) treatment prevents relapse has also been documented in the treatment of depression (Fava et al., 2004; Hensley, Nadiga, \& Uhlenhuth, 20041. In the treatment of major depressive disorder, the proportion of patients being in remission up to two years after treatment was higher after cognitive therapy than after antidepressant medication (Hensley et al., 2004). Furthermore, a cognitive behavioral treatment after successful antidepressant therapy for depression prevented relapse for at least six years after treatment (Fava et al., 2003). In line with these findings, the present findings clearly indicate that CBT is effective on the 
long-term, also in obesity treatment. Little is known, however, about the precise working mechanisms of CBT. Wilson and colleagues recently published a study designed to dismantle the specific mechanism of action for CBT in the treatment of bulimia nervosa. In accordance with the main goal of their treatment (i.e., the reduction of dietary restraint), they concluded that restraint reduction early in treatment was the most clearcut mediator of treatment outcome (i.e., binge eating and purging) (Wilson, Fairburn, Agras, Walsh, \& Kraemer, 2002). In the present study, the cognitive treatment was specifically targeted to changing dysfunctional cognitions about eating, weight and shape, assuming that these factors play a significant role in the maintenance of obesity. Analyses by intention to treat revealed that - as hypothesized - CBT was more effective in reducing concerns about eating and weight than SBT. Possibly, CBT prevented weight gain by directly changing these dysfunctional thoughts. However, this study was not designed for mediation analyses and explanations for CBT"s mechanism of action in the present study are only tentative.

After treatment, participants scored higher on restraint. According to restraint theory, dieting precedes binge eating (Polivy \& Herman, 1985; 1993). However, support for this model is inconsistent. While self-reported dieting seemed a precursor for eating pathology in several studies, experimental manipulations of caloric intake led to decreased eating pathology in others (for a review see Stice, 2002). In a recent randomized clinical trial the effects of dieting on the onset of bulimic pathology were investigated. In contrast to the hypothesis of the dietary restraint model, it was found that assignment to a low-calorie diet decreased bulimic symptoms (Presnell \& Stice, 2003). The results of the present study are in line with these findings as after treatment, eating disorder specific psychopathology - concerns about eating, weight and shape and binge eating - decreased. It is recently suggested that the occurrence of a third variable, accounting for dieting as well as for overeating, might explain why self-report studies do but experimental studies do not find dieting and binging to be causally related. Thus far, the nature of this third variable remains unclear, although a tendency towards overeating and impulsivity have been suggested Jansen et al., 2003; Nederkoorn, Van Eijs, \& Jansen, 2004; Nederkoorn, Braet, Van Eijs, \& Jansen, 2004; Ouwens, van Strien, \& van der Staak, 2003; Stice, 2002; Stice, Cameron, Killen, Hayward, \& Taylor, 1999).

Within the present sample of obese people that were seeking treatment for their weight problems, $42 \%$ scored ten or more on the $\mathrm{BDI}$. Almost half of the clients registering for diet management by a dietician thus were characterized as being mildly to moderately depressed, according to the cutoff scores of the BDI (Beck et al., 1988). For this subgroup of participants with depressive symptoms the superiority of the cognitive treatment was even more prominent, mainly in the intention to treat analyses. This is even more striking given the small number of participants in the symptomatic subgroup. Apparently, overweight and obese people with depressive symptoms are a subgroup that is specifically well treated by cognitive therapy.

Although the present study was carefully designed, its practical setting caused some methodological flaws. First, comparing participants in both treatments on outcome measures 
of interest before treatment showed that randomization did not result in completely comparable groups. Second, dropout analyses revealed selective dropout; people in the SBT and people with a higher pretreatment EDEQ global score were more likely to drop out of treatment. Intention to treat analyses revealed superiority of the CBT in reducing concerns about eating and weight. Although we can only guess about what would have happened if the dropouts would have completed the treatment, the selective dropout might have (partly) been responsible for these results. However, the superiority of CBT for BMI seems robust as this effect was shown by both the intention to treat analyses and the complete cases analyses. Third, binge eating could not be assessed by interview for practical reasons. Since it has repeatedly been reported that binge eating is not reliably measurable by the EDEO (Fairburn \& Beglin, 1994; Kalarchian et al, 2000; Wilfley et al., 1997), we developed an open ended questionnaire to additionally measure binge eating. The percentage of bingers in our study was lower than that found in other studies (e.g. De Zwaan et al., 2004; Johnson et al., 2003; Spitzer et al., 1992), and the psychometric quality of this questionnaire needs further investigation. However, the population of interest was different in the other studies in that the researchers specifically asked for people seeking treatment for binge eating or weight loss (De Zwaan et el., 1994; Johnsen et al., 2003).

Fourth, the short term results of the treatment were similar for CBT and SBT. In both treatments, participants improved on all psychological measures and weight. Since there was no no-treatment control group in the present study, we cannot be sure about these positive effects of time reflecting a pure effect of treatment. However, previous research has shown that (cognitive) behavior treatments are superior to no-treatment control groups in the treatment of bulimia nervosa and binge eating disorder (e.g. Agras et al., 1995; Eldredge et al., 1997; Marcus, Wing, \& Fairburn, 1995; Peterson et al., 1998; Telch et al., 1990; Wilfley et al., 1993. Furthermore, the finding that participants had a lower BMl one year after treatment than before treatment is clinically significant in itself, as time trend studies show that the prevalence of obesity increases with age (e.g. Visscher et al., 2002). Unfortunately, as many studies have shown before, participants in the standard behavior treatment regained part of the weight they lost during treatment. That this was not the case for participants in the cognitive treatment is encouraging. To investigate very long term effects of the cognitive treatment, however, five- or even ten year follow-ups would be necessary.

Participants who completed treatment lost almost $5 \%$ of their weight $(4.8 \%)$. To reduce health risks, weight losses of $5-15 \%$ of the initial body weight are advised (Institute of Medicine, 1995; NIH/NHLBI, 1998; U.S. Department of Agriculture, 1995]. The finding that this weight reduction was maintained after the cognitive behavioral treatment indicates that this type of treatment succeeds in achieving clinically significant weight losses. As mentioned before, howevel, about $20 \%$ of the participants dropped out of treatment. Although this percentage is comparable to that reported in related studies (e.g., Agras, Walsh, Fairburn, Wilson, \& Kraemer, 2000; Dansinger, Gleason, Griffith, Selker, \& Schaefer, 2005), it means that one in every five treatment starters not even showed up more than half of the treatment sessions. These so called 
dropouts however, do consume time and effort of the therapist (dietician) and one could argue that in practical settings like the present study, this high percentage of dropouts is realistic. The analyses based on intention to treat - in which the dropouts are included might therefore reflect more realistic treatment effects than the completers analyses. For the results of the present study, this points to a superiority of the cognitive behavioral treatment. Although participants in both treatment conditions benefited from the treatment, BMI and the positive results for eating-and weight concerns were better maintained in the cognitive group. Adding cognitive therapy to the regular treatment for obesity by dieticians might thus be a valuable step in optimizing these treatments. Particularly those overweight and obese people who score above ten on the BDI benefited from the cognitive treatment. For dieticians, the BDI could be used as an easy to administer and helpful tool to select those overweight and obese people with depressive symptoms, and to refer them to an appropriately trained cognitive behavior therapist. 


\section{CHAPTER 6}

\section{EARLY ASSOCIATIONS WITH PALATABLE FOODS IN OBESITY ARE NOT DISINHIBITION RELATED BUT RESTRAINT RELATED}

Submitted for publication as: Werrij, M. Q.,. Roefs, A., Janssen, l., Stapert, D., Wolters, G., Mulkens, S., Hospers, H. J., \& Jansen, A. (2005). Early associations with palatable foods in obesity are not disinhibition related but restraint related. 
Chapter 6

\section{ABSTRACT}

Obese people prefer and overconsume high-fat foods, and at the same time they try to restrain their eating behaviour attempting to lose weight. Based on the findings that restrained eaters disinhibit in a variety of situations, and on cognitive theory's assumption that cognitions underlie behaviour, we hypothesized that concepts of disinhibition and palatable foods are related on a cognitive level, particularly in the obese. This hypothesis was tested within the semantic priming paradigm. In study 1,24 overweight $/$ obese and 19 normal weight women participated. The data did however not support an association between disinhibition and palatability. Possibly, this association was not found because early associations with palatability are already directed at the unhealthy consequences of the high-fat palatable foods. Study 2 therefore investigated associations between restraint and palatable foods within the same paradigm. Participants were 27 obese and 29 normal weight women. Results indicate that the presentation of palatable food words facilitated accessibility of restraint concepts as hypothesized. There were no group differences. Clearly, early associations to palatability are restraint related in both normal weight and obese people. 
In industrialized countries palatable high-fat foods are available in large variety. The presence of so much palatable food typically induces an ambivalence (Sparks, Conner, James, Shepherd, \& Povey, 2001), of being attracted by the delicious taste of the foods on the one hand le.g., Drenowski, 1989, 1997), and considering the negative health related consequences of consuming them on the other hand (e.g., Bowen, Tomoyasu, Anderson, Carney, \& Kristal, 1992; Wardle \& Solomons, 1994). However, although attitudes towards palatable foods often are ambivalent, people generally eat more of palatable foods than of unpalatable foods (Pliner, Herman, \& Polivy, $1990)$.

Especially for obese people it is a challenge to appropriately manage the abundance of highfat palatable foods, as they have been found to be more sensitive to the fattiness and palatability of foods than people of normal weight. Obesity has been associated with both a preference for high-fat foods and elevated consumptions of these foods (e.g., Drenowski, 1991, 1997; Rissanen et al., 2002). Obese people furthermore are more responsive to the palatability of foods, as they were repeatedly found to consume more of palatable foods than normal weight controls in laboratory settings. Little evidence was found however for obese people eating less of unpalatable food (for a review see Pliner et al., 1990). For those people trying to restrain their eating pattern, in an attempt to control their weight, this impressionability for high-fat palatable foods could well be a burden.

Obese people frequently wish to - and are advised to - lose weight by reducing their energy intake and thus restraining their eating behaviour. Restraint theory (Herman \& Polivy, 1984) posits that restrained eaters have their own self-imposed diet boundary, in contrast to unrestrained eaters who not have such a boundary. While normal, unrestrained eaters eat until they are satiated, restrained eaters stop eating when their diet boundary is reached. Exceeding this boundary, according to the theory, leads to disinhibition, causing the restrained eater to overeat. This phenomenon of counterregulation has been investigated extensively in several laboratory studies, and in support of the disinhibition hypothesis, restrained eaters were indeed found to disinhibit after disruptions in self-control such as eating or anticipating a (perceived) high caloric preload, while unrestrained eaters were not (for a review see Ruderman, 1986). However, restrained eaters also showed disinhibited eating in situations in which self-control was not released, such as merely smelling high caloric food (Jansen \& van den Hout, 1991), or when a negative mood was induced (Baucom \& Aiken, 1981; Chua, Touyz, \& Hill, 2004; Frost, Goolkasian, Ely, \& Blanchard, 1982). Thus, the precise mechanism underlying the proposed phenomenon of disinhibition is still not clear. Furthermore, though dieting and binging are associated, not much support has been found for the assumed causal relation between these two (Stice, 2002).

In sum, obese people prefer high-fat foods and they tend to overconsume them. Considering most obese people's wish to lose weight, eating too much fat is not recommended. Furthermore, although we cannot pronounce upon causality, overeating in those people who try to restrain their eating behaviour is not uncommon. It is therefore an interesting question what causes (obese) people to disinhibit in the presence of palatable foods. Cognitive theory states that 
cognitions are the basis of amost all behaviour. Not the situation per se, but rather people"s interpretation of the situation triggers behaviour. Dysfunctional (automatic) cognitions are assumed to underlie several forms of psychopathology (Beck, 1976), and cognitions might play a significant role in disturbed eating behaviour as well (e.g., Cooper \& Fairburn, 1992). So according to a cognitive approach - if (dysfunctional) disinhibiting thoughts automatically come into obese people's minds when confronted with palatable high fat foods, overeating is likely to occur. In the present study this relation between disinhibiting thoughts and palatable foods is investigated.

In several studies, cognitions were measured explicitly by the use of self report measures (e.g., Cooper, Cohen-Tovee, Todd, Wells, \& Tovée, 1997), interviews (e.g., Nauta, Hospers, Jansen, \& Kok, 2000), thought listing procedures, (e.g., Boon, Stroebe, Schut, \& Jansen, 1998) or the taping of thoughts le.g., Hickford, Wards, \& Bulik, 1997; Jansen, Merckelbach, Oosterlaan, Tuiten, \& van den Hout, 1988). The use of self-report measures, however, has several shortcomings. First, participants' responses to them might be strategically controlled or susceptible to demand characteristics. Second, behaviour is not always preceded by deliberate considerations, but in some cases follows from spontaneous and relatively automatic processes. In the latter case, selfreport measures may not be appropriate (e.g., De Houwer, 2002; De Houwer, 2003; De Jong, Pasman, Kindt, \& van den Hout, 2001; Gemar, Segal, Sagrati, \& Kennedy, 2001). In the present study, cognitions will therefore be investigated by an indirect measure (i.e., a semantic priming task). Following Zack, Toneatto and MacLeod (1999), we use the semantic priming paradigm (Neely, 1991) to study the cognitive associations between the concepts of interest - palatable foods and disinhibition. In this paradigm two word stimuli, a prime followed by a target, are presented on the computer screen in quick succession. Participants are urged to decide as quilckly as possible whether the target is a word or a nonword (i.e., a lexical decision task). If semantic priming occurs, lexical decisions to a target word are faster and more accurate when prime and target are related then when they are not. Thus, participants are faster in deciding whether butter is a word or a nonword when it is preceded by bread than to butter preceded by doctor:

The semantic priming task that we used is a so-called indirect measure. Indirect means that a participant is not directly asked for an evaluation or association. Instead, task performance informs us about the participant's evaluations or associations. The semantic priming task that we used, aims to measure relatively automatic associations. As De Houwer (in press) points out, automaticity is not an all-on-none feature, and it has to be specified which criteria of automaticity are tnet by the employed indirect measure. Responses in the semantic priming task can be characterized as unintentional, in that participants do not intentionally use the prime to respond to the target. Moreover, time for controlled processing in limited because the stimuli are presented in quick succession, and participants have to respond as quickly as possible. An advantage of indirect measures is that influences of social desirability and possibilities for participants to strategically control their responses are minimized. 
If the concepts of palatable foods and disinhibition are semantically telated, priming with one concept will facilitate responding to the other. It is therefore expected that participants will respond faster to a disinhibition target (e.g., to stuff) when it is preceded by a palatable food prime (e.g., chocolate), than when the target is preceded by a neutral prime (e.g., lamp). We expect this effect to be more pronounced in overweight/ obese participants than in a contral group of normal weight participants (hypothesis 1). It is furthermore expected that participants will respond faster to a palatable food target when it is preceded by a disinhibition prime than when it is preceded by a neutral prime. Again, we expect this effect to be more pronounced in overweight/ obese participants than in participants of normal weight (hypothesis 2).

\section{STUDY 1}

\section{METHOD}

\section{Participants}

Twenty-four overweight and obese women (BMI > 27) and 19 women of normal weight (BMI 19. 25) participated in this study. Participants were recruited by advertisements in a local newspaper. Inclusion criteria were BMI (overweight/ obese group BMI > 27, control group BMI 19-25) and age (19-60 years). Exclusion criteria were pregnancy and the presence of apparent medical conditions responsible for obesity. Furthermore, normal weight participants were excluded if theif eating pattern was restrained, i.e., if they scored 15 or more on the Restraint Scale (RS; Herman \& Polivy, 1980). Overweight obese and normal weight participants were matched on age.

\section{Overview semantic priming paradigm}

During the task, prime and target words were presented on the computer screen in quick succession. Participants had to perform a lexical decision task upon presentation of the target (word/ nonword). Stimuli were presented in blocks per target type. In block type A, primes were palatable foods or neutral words, targets were disinhibition words or nonwords. In block type B, primes were disinhibition or neutral words, targets were palatable foods or nonwords. Lexical decisions were made by pressing the left or the right button on an external key-box [key-assignment was counterbalanced over participants]. The dependent variable is the keypress latency in response to the target.

\section{Stimulus selection and timing of the trials}

Palatable foods and disinhibition related words were selected in a pilot study. The goal of this pilot study was to determine 1$\}$ generally liked high-fat foods, assuming high-fat foods to elicit disinhibiting thoughts more than low-fat foods, and 2) words covering the disinhibition concept. Sixty-four students completed the palatabie-food part of the pilot study /vegetarians were left out of the analyses), 67 stucents completed the part concerning disinhibition related words. 
Selection of palatable foods. Participants were given a lists of 28 high-fat foods. They had to choose the eight most liked and eight most disliked foods, and rank them from \/like/ dislike the most) to 8 (like / dislike least). The twelve most liked high-fat foods were selected by multiplying the mean ranking of a food by the number of participants that put the food item in their selection (see appendix).

Selection of disinhibition related words. After introducing the concept of disinhibition to the pilot participants, they were provided with a list of 34 disinhibition related words. Participants first had to indicate which words they thought represented the concept of disinhibition, by crossing out the non-representative words. Then, on their list of remaining representative words, participants had to rank the twelve most representative words from 1 (most representative of the concept of disinhibition) to 12 (least representative). Again, stimulus selection for the current experiment was based on the mean ranking of the words, weighted by the number af participants that put the words in their selection of most representative words. This way, the twelve words that were most representative for the concept of disinhibition were selected (see appendix].

Selection of neutral words. Similar to Zack et al. 11999) we based our neutral words on two categories, in the present study being "things you find in a living room" and "things you find in an office". Neutral words were matched to food and disinhibition stimuli on objective frequency of occurrence in print (Celex Lexical Database, Dutch frequency lemma's) and number of letters. Because disinhibition words had more letters $(M=9.3)$ than palatable foods $(M=6.0 j, t(22)=3.85, p<.001$, and stimuli of interest were matched to neutral words on frequency of occurrence in print and number of letters, both stimuli types were matched to their own category of neutral words. Living room words were matched to palatable foods; office words were matched to disinhibition words. Living room words (LR) did not differ from palatable foods (PF) in frequency of occurrence $\left(M_{\mathrm{LR}}=0.4, M_{\mathrm{PF}}=0.4\right), t(22)<1$ nor in number of letters $\left(M_{\mathrm{LR}}=6.0, M_{\mathrm{pF}}=6.0\right), t(22)<1$. Office words $(O)$ and disinhibition words (D) also did not differ in frequency of occurrence $\left(M_{\mathrm{O}}=0.4, M_{\mathrm{D}}=(0.3), t(22)<1\right.$ or number of letters $M_{0}=8.9, M_{0}=(9.3), t(22)<1$.

Construction of nonwords. Nonwords were obtained by matching each word with a word of equal frequency of occurrence in print and number of letters, and then randomly replacing a vowel and a consonant in the matched word (following Zack et al., 1999). When a matched word consisted of two words (e.g., table tennis; Dutch = tafeltennis) one letter in the first part of the word and one letter in the last part of the words was changed. It was randomly assigned whether first a vowel and then a consonant were replaced or vice versa. This way, pronounceable nonwords were obtained (e.g., hafeltennes).

Timing of a trial. At the beginning of each trial, a fixation stimulus $(t+t+)$ was presented for $250 \mathrm{~ms}$, followed by a blank screen ( $250 \mathrm{~ms}$ ), presentation of the prime (750 ms), and presentation of the target (until response), following the procedure used by Zack et al. (1999). The inter trial intervall was $1000 \mathrm{~ms}$. 
Randomization of stimuli. In total, 212 trials were presented. The first 20 trials were practice trials containing stimuli that did not appear in the actual task, using animals as primes and musical instruments as targets. Practice trials were followed by four experimental blocks, in each of which 48 trials were presented. The four blocks were organized per target category (disinhibition or palatable food). Part A (disinhibition targets) contained two prime-target conditions: 1) neutral - disinhibition and 2) palatable food - disinhibition. Part B (palatable foods) contained two other prime - target conditions: 3) neutral - palatable food and 4) disinhibition - palatable food. In each block, half of the primes were neutral. Within each block, presentation of the trials was randomized. Order of part A and B was counterbalanced over participants. In each prime-target condition, half of the targets were words and half were nonwords. Wordword trials and word - nonword trials were presented at random.

\section{Stimuli check}

To check the palatability of the high-fat palatable foods, participants were asked to rate the palatable food stimuli on palatability ( $1=$ dislike a lot $-7=$ like a lot $)$. None of the food stimuli was considered unpalatable by the participants, with chocolate having the highest score on palatability $(M=6.0)$ and hamburger the lowest score $(M=4.5)$. Next, disinhibition words and palatable foods were rated on familiarity, to check whether participants were differently familiar with one type of stimuli than with the other. Participants had to indicate how often they thought to have heard or seen the word $(1=$ never $-7=$ very often). Participants were relatively more unfamiliar with disinhibition words $(M=3.5)$ than with palatable foods $(M=$ $5.0), t(42)=7.17, p<.001$. However, palatable food primes and disinhibition primes appeared in separate target conditions, with their matched neutral words as neutral primes.

\section{Procedure}

Participants were tested individually. Upon entering the laboratory, participants were provided with general information about the study and after signing the informed consent form, they were seated in front of the computer Instructions for the task were presented on the computer screen and if needed elucidated orally. Participants were instructed to read the prime, but only respond to the target. They had to decide as quickly as possible, while avoiding making too many mistakes, whether the target was a word or a nonword by pressing the corresponding key on an external key-box. After the practice trials, participants were asked to write down as many primes as they could remember. This free recall task was only administered to ensure continued attention to the primes, and data of the free recall task were not analyzed. Before the beginning of the experimental trials, the instructions were repeated on the monitor. Then the four experimental blocks were presented. After each block, participants could take a short break. At the end of the computer task participants had to perform another free recall task, similar as the previous one. Finally, the stimuli check questionnaires were administered and body height and weight were measured. Before leaving the research room, participants were debriefed, paid $€ 10$,- and asked not to talk about the purpose of the study with others. 


\section{Apparatus}

The experiment was carried out on a Dell Optiplex GX260 computer with a Dell 19 inch monitor. Responses were recorded by an extemal response device with better than one millisecond accuracy. The lexical decision task was programmed in ERTS (Experimental Run Time System, Beringer, 1996).

\section{Design and analyses}

Data were analyzed separately for each target type (disinhibition vs palatable food). For trials with disinhibition targets, a 2 (group: overweight/ obese vs normal weight) x 2 (prime: neutral vs palatable food) ANOVA was performed (hypothesis 1). For trials with palatable food targets, a 2 (group: overweight/obese vs normal weight) $\times 2$ (prime: neutral vs disinhibition) ANOVA was performed (hypothesis 2). Prior to the analyses of the semantic priming task, participants in the two groups were compared on relevant characteristics (age, BMI, Restraint Scale) by t-tests. If Levene's test for equality of variances showed significance, results of the $t$ test with equality of variances not assumed were reported.

\section{RESULTS}

\section{Participant characteristics}

Based on the criterion $(\geq M+3 S D)$ for the percentage of responses that were either erroneous, too fast (RT $<100 \mathrm{~ms}$ ) or too slow (RT. $>3000 \mathrm{~ms}$ ), none of the participants had to be excluded.

Mean age of the overweight obese group was 42 years $(S D=10.3$; range $21-58)$, mean age of the control group was 41 years $[S D=12.0$, range $21-56)$. The groups did not differ significantly in age, $t(41)<1$. Mean BMI of the overweight/ obese group was 33.7 ( $S D=5.6$, range $27.3 \cdot 49.6)$, mean $\mathrm{BMI}$ of the control gloup was $22.1(S D=1.6$, range 19.6 - 24.8). BMI differences between the groups were obviously significant, $t(27.5)=9.75 p<.001$. Mean score on the RS was $15.7(S D=3.7$, range $9-23)$ in the overweight obese group and 8.1 $(S D=2.7$, range $4-12)$ in the control group. RS scores differed significantly between the

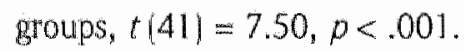

\section{Analyses priming task}

Analyses were performed for the dependent variables response latency (speed) and percentage of errors (accuracy). Response latencies for responses that were either too fast (RT $<100 \mathrm{~ms}$ ) on 100 slow (RT $>3000 \mathrm{~ms}$ ) were discarded $10.4 \%$ of the responses). Response latencies for error responses were also discarded (2.3\% of the responses). Because analyses on the percentage of errors did not reveal any significant effects, only analyses on response latencies will be reported'.

1. Analyses were alsoperformed on the log wansfomed latencies. These analyses did not lead to differentesuts 
Table 6.1: Mean response latencies [SE] in ms to disinhibition targets and palatable food targets.

\begin{tabular}{|c|c|c|c|c|}
\hline & \multicolumn{2}{|c|}{$\begin{array}{l}\text { Target Disinhibition } \\
\text { (Hypothesis } 1)\end{array}$} & \multicolumn{2}{|c|}{$\begin{array}{l}\text { Target Palatable Food } \\
\text { (Hypothesis } 2)\end{array}$} \\
\hline & $\begin{array}{l}\text { Prime } \\
\text { Neutral }\end{array}$ & $\begin{array}{c}\text { Prime } \\
\text { Palatable food }\end{array}$ & $\begin{array}{l}\text { Prime } \\
\text { Neutral }\end{array}$ & $\begin{array}{l}\text { Prime } \\
\text { Prime Disinhibition }\end{array}$ \\
\hline Normal weight & $646.5(29,1)$ & $6543(28.3)$ & $617.6(27.9)$ & $628.1(30.01$ \\
\hline Obese & $691.6(25.9)$ & $6883(25.2)$ & $657.3(24.8)$ & $666.3(26.7)$ \\
\hline
\end{tabular}

Results for disinhibition targets (hypothesis 1). It was hypothesized that participants would respond faster to a disinhibition target after a palatable food prime than after a neutral prime, and that this effect would be most pronounced in the overweight/obese group. No support for this hypothesis was found: no main effect of prime, $F(], 41)<1$ and no interaction of group and prime, $F(1,41)<1$ emerged. These results indicate that responses to a disinhibition target after a palatable food prime were just as fast as those after a neutral prime (main effect prime), and that this was the case for both the overweight/ obese group and the normal weight group (group $x$ prime interaction). Overall, there were no differences in response latencies between overweight / obese people and normal weight people either, as was shown by a nonsignificant main effect of group, $F(1,41)=1.10, p=.30$. The mean response latencies are presented in Table 6.1 .

Results for palatable food targets (hypothesis 2). No support for our second hypothesis - that participants would respond faster to a palatable food target after a disinhibition prime than after a neutral prime, and that this would be most pronounced in the overweight / obese group - was found. The main effect of prime, $F(1,41)=2.19, p=.15$ nor the group x prime interaction, $F(1,41)<1$ were significant. These results indicate that participants responded equally fast to a palatable food target after a disinhibition prime, and after a neutral prime. The main effect of group was not significant either, $F[1,41)=1.04, p=.31$, meaning that overall, response latencies were the same in the overweight/ obese group and in the normal weight group. Relevant means are presented in Table 6.1 .

\section{DISCUSSION}

In the present study, we examined the association between the concepts of palatable food and disinhibition in overweight / obese and nomal weight participants in a semantic priming paradigm. The hypothesized cognitive association between the concepts of palatable foods and disinhibition was not found. Although several factors could have caused the nonsignificant findings, it is not likely that the semantic priming paradigm was chosen inaccurately. We thoroughly followed the procedure used by Zack and colleagues [Zack et al., 1999) in their study on the association of negative affective cues and alcohol concept in problem drinkers. 
They predicted negative affective cues to activate alcohol concepts, and vice versa, in problem drinkers with high psychiatric distress, but not in problem drinkers with low psychiatric distress. They found support for these hypotheses. The paradigm therefore seems appropriate for examining the cognitive association between two related concepts in a clinical population.

Possibly, the hypothesized association between palatable foods and disinhibition was not fourid because early associations with high-fat palatable foods are already directed at the negative health related consequences of these foods. Neumark Sztainer et al. (2000) found that more than half of their study population engaged in some kind of weight control behaviour. This suggests that weight control is an issue for a large percentage of the population. Particularly overweight and obese people. may know that high fat foods are very unhealthy and fattening. Therefore, instead of disinhibition related associations, these palatable foods may have elicited restraint associations. In a second study, it will therefore be tested whether palatability is associated with restraint, using the same paradigm as in the current study. Furthermore, to enlarge the contrast between the two weight groups, only obese people will be included (BMI $>30$ ) in this second study. We expect that participants will respond faster to a restraint target when it is preceded by a palatable food prime, than when the target is preceded by a neutral prime. We expect this effect to be more pronounced in obese participants than in a control group of normal weight participants (hypothesis 1). We furthermore expect that participants will respond faster to a palatable food target when it is preceded by a restraint prime than when it is preceded by a neutral prime. Again, we expect this effect to be more pronounced in obese participants than in participants of normal weight (hypothesis 2).

\section{STUDY 2}

\section{METHOD}

\section{Participants}

Twenty-eight obese women (BM) > 30) and 29 women of normal weight (BMI 19-25) participated in this study. Like in study 1 , normal weight participants were recruited by advertisements in a local rewspaper. In study 2 however, obese women were recruited through the Department of Medical Psychology of the Atrium Hospital in Brunssum, a hospital in the south of the Netherlands. Women amnouncing for bariatric surgery, and visiting the hospital psychologist for a psychological screening, were invited to participate in the study. The BMI inclusion criterion for the obese group was 30 or more, the other inclusion and exclusion criteria were the same as in study 1 . Obese and normal weight participants again were matched on age.

\section{Overview semantic priming paradigm}

The same semantic priming task was used as in study 1 . In block type $A$, primes now were palatable foods or neutral words, targets were restraint words or nonwords. In block type $B$, primes were restraint on neutral words, targets were palatable foods or nonwords. 


\section{Stimulus selection and timing of the trials}

Selection of the stimuli. Palatable foods were identical to those used in study 1. Restraint words were selected by a pilot study similar to that in study 1 . Forty-two female students of Maastricht University completed the questionnaire. Based on the pilot study, the twelve words that were most representative for the concept of restraint were selected (see appendix). Neutral words again were "things you find in a living room" and "things you find in an office", matched on objective frequency of occurrence in print and number of letters, to food and restraint stimuli respectively. The living room words and palatable foods were the same as in study 1 , and did not differ in frequency of occurrence or number of letters (see study 1). Office words $(O)$ and restraint words (R) also did not differ in frequency of occurrence $\left(M_{0}=1.0, M_{\mathrm{R}}=1.2\right), t(22)$ $<1$ or number of letters $\left(M_{\mathrm{O}}=6.8, M_{\mathrm{R}}=7.0\right), t(22)<1$. Nonwords were constructed in the same way as in study 1 .

Timing of a trial and randomization of stimuli. Trial timing and stimuli randomization was similar to study 1 . The four prime - target conditions were: 1 | neutral - restraint, 2) palatable food - restraint, 3) neutral - palatable food, 4) restraint - palatabie food.

\section{Stimuli check}

Food preferences and subjective familiarity with palatable food and restraint words were measured on a 7-point scale (see study 1). None of the food stimuli was considered unpalatable by the participants, with French fries having the highest score on palatability $(M=6.1)$ and doughnut ball the lowest score $(M=4.6)$. Participants were as familiar with restraint words $(M=5.0)$ as with palatable foods $(M=4.8), t(51)=1.65, p=.11$.

\section{Procedure}

The experiment took place in a research room at the Atrium Hospital in Brunssum. The procedure was identical to study 1 .

\section{Apparatus}

The experiment was carried out on a Dell Inspiron 5000e notebook computer wilth a Pentium 3 processor and a Philips Briliance 10515 inch monitor. Responses were recorded by an external response device with better than one millisecond accuracy. The lexical decision task was programmed in ERTS (Experimental Run Time System, Beringer, 1996).

\section{Design and analyses}

Data were analyzed separately for each target type (restraint vs palatable food). For trials with restraint targets, a 2 (group: obese vs normal weight) $\times 2$ (prime: neutral vs palatable food) ANOVA was performed (hypothesis 1). For trials with palatable food targets, a 2 (group: obese ws normal weight) $\times 2$ (prime: neutral vs restraint) ANOVA was performed (hypothesis 2). Prior to the analyses of the semantic priming task, participants in the two groups were compared on 
relevant characteristics (age, BMI, Restraint Scale) by ttests. If Levene's test for equality of variances showed significance, results of the test with equality of variances not assumed were reported.

\section{Results}

\section{Participant characteristics}

One (obese) participant was excluded from analyses because of a high percentage $₫ \geq M+3$ $S D$ J of errors or responses that were either too fast (RT $<100 \mathrm{~ms}$ ) or too slow (RT $>3000 \mathrm{~ms}$ ), on the semantic priming task. The analysed group thus consisted of 27 obese and 29 normal weight women.

Mean age of the obese group was 37 years $(S D=8.9$; range $22-57)$, mean age of the control group also was 37 years $(S D=8.5$, range $20-55)$. The groups did not differ significantly in age, $t(54)<1$. Mean $\mathrm{BMI}$ of the obese group was 40.3 ( $S D=7.5$, range $30.1-65.6)$, mean $\mathrm{BMI}$ of the control group was 22.1 (SD $=1.7$, range 18.1-24.8). As expected, BMI differences between the groups were significant, $t(28.6)=12.27, p<.001$. Mean score on the RS was $18.7(S D=3.8$, range $12-24)$ in the obese group and $8.6(S D=3.2$, range $=2-14)$ in the control group. RS scores differed significantly between the groups, $t(54)=10.85, p<.001$.

\section{Analyses priming task}

Analyses were performed for the dependent variables response latency (speed) and percentage of errors (accuracy). Response latencies for responses that were either too fast (RT $<100 \mathrm{~ms}$ ) or too slow (RT $>3000 \mathrm{~ms}$ ) were discarded $[0.2 \%$ of the responses). Response latencies for error responses were also discarded $(0.8 \%$ of the responses). Because analyses on the percentage of errors did not reveal any significant effects, only analyses on response latencies will be reported ${ }^{2}$,

Table 6.2: Mean response latencies (SE) in mis to restraint targets and palatable food targets.

\begin{tabular}{|c|c|c|c|c|}
\hline & \multicolumn{2}{|c|}{$\begin{array}{l}\text { Target Restriaint } \\
\text { (Hypothesis } 1 \text { ) }\end{array}$} & \multicolumn{2}{|c|}{$\begin{array}{c}\text { Target Palatable Faad } \\
\text { (Hypothesis 2) }\end{array}$} \\
\hline & $\begin{array}{l}\text { Pilme } \\
\text { Neutral }\end{array}$ & $\begin{array}{l}\text { Piime } \\
\text { Palatable food }\end{array}$ & $\begin{array}{l}\text { Prime } \\
\text { Neutral }\end{array}$ & $\begin{array}{l}\text { Prime } \\
\text { Restraint }\end{array}$ \\
\hline Normal weight & $799.4(313)$ & $785.8(32,4)$ & $7606(28.4)$ & $7855(30.1)$ \\
\hline Obese & $7901(32.4)$ & $7682(336)$ & $7873(29.4)$ & $790.2(31.2)$ \\
\hline
\end{tabular}

2. Analyses were allso performed on the log transtomed latencies. These analyses dit not lead to different results. 
Results for restraint targets (hypothesis 1). It was hypothesized that participants would respond faster to a restraint target after a palatable food prime than after a neutral prime, and that this would be most pronounced in the obese group. Supporting our first hypothesis, a significant main effect of prime was found, $F(1,54)=5.23, p<.03$. Inspection of the means shows that overall, participants responded faster on restraint targets after a palatable food prime than after a neutral prime (see Table 6.2 for the mean response latencies). However, the expected interaction of group and prime was not significant, $F(1,54)<1$, indicating that this main effect was not qualified by weight status. The main effect of group was not significant either, $F(\mathbb{1}, 54)<1$, indicating that there were no overall differences in response latencies between the two wejght groups.

Results for palatable food targets (hypothesis 2). The data did not support our second hypothesis - that participants would respond faster to a palatable food target after a restraint prime than after a neutral prime, and that this effect would be most pronounced in the obese group. The main effect of prime, $F(1,54)=2.63, p=.11$, and the interaction of group and prime, $F(1,54)=1.63, p=.21$, were not significant. These results indicate that responses to a palatable food target after a restraint prime were just as fast as those after a neutral prime (main effect prime), and that this was the case for both weight groups (group x prime interaction). The main effect of group was not significant either $F(1,54)<1$, indicating that there were no overall differences in response latencies between the obese and the normal weight group. Relevant means are presented in table 6.2 .

\section{Discussion}

In the second study, we examined the association between the concepts of palatable food and restraint in obese and normal weight participants, within the semantic priming paradigm. We hypothesized that participants would respond faster to a restraint target when it was preceded by a palatable food prime, than when the target was preceded by a neutral prime, and we expected this effect to be more pronounced in obese participants than in a control group of unrestrained normal weight participants. The first hypothesis was partially supported as respondents responded more quickly to a restraint target after a palatable food prime than after a neutral prime. There were, however, no differences between the obese and normal weight group. Support for the second hypothesis, that participants - and obese participants in particular would respond faster to a palatable food target preceded by a restraint prime than to a palatable food target preceded by a neutral prime, was not found.

In the present study, the presentation of a palatable food word faclitated accessibility of restraint related concepts, as hypothesized. Thus, on a relatively automatic level there is already an association between palatability and restraint. Many people know that eating too much high. fat food is bad for one's health and makes one gain weight; explicit attitudes towards high-fat foods in general are more negative than attitudes towards low-fat foods. (Stafleu, de Graaf, van 
Staveren, \& de Jong, 1994). That high-fat foods were found to elicit self-reported restraint related thoughts in restrained as well as in unrestrained eaters (Boon et al., 1998) is in line with the present data. However, this is the first study that shows that the association between high-fat foods and restraint already is measurable on a relatively automatic level.

Roefs and Jansen (2002) used an indirect measure to study attitudes towards high-fat foods in obesity. In line with the present results, their nornal weight and obese participants showed a negative attitude toward high-fat foods on the Implicit Association Test (IAT; Greenwald, McGhee; \& Schwartz, 1998]. However, whereas in the present study no group differences were found, on the IAT the negative attitude toward high-fat foods was stronger for the obese group (Roefs \& Jansen, 2002). Possibly, these divergent results could be explained by the fact that two very different tasks were used. In the IAT, the fat content of food is made particularly salient because participants have to categorize food items as high-fat or low-fat. In the semantic priming task, fat content was not that sallient because participants did not have to focus on the fat content of the presented foods, but on the semantic aspects (word or nonword) of the target items. Moreover, correlations between different indirect measures were recently found to be surprisingly low, suggesting that they do not measure the same underlying construct (Bosson, Swann, \& Pennebaker, 2000; Olson \& Fazio, 2003).

In sum, palatable food cues facilitated the accessibility of restraint words. The reverse, however, was not true. The lack of an automatic association between restraint and palatability in obese participants gives hope. This finding suggests that restraining food intake does not make one hyperreactive to palatable foods. It is encouraging to know that restraint does not automatically activate good taste associations.

\section{GENERAL DISCUSSION}

In the present study, it was hypothesized that concepts of palatability and disinhibition (study 1) and palatability and restraint (study 2) are associated on a relatively automatic level. However, no support was found for an association between palatable foods and disinhibition concepts [study 1]. In contrast, it was found that palatable food cues activate restraint related concepts (study 2). Apparently, early associations with palatable foods are not disinhibition but rather restraint related. On the early cognitive level, the obese are - like normal weight people characterized by associations that point to refraining from eating when confronted with palatable food words.

A most relevant question, then, is why obese people generally eat more calories than they need, although their early automatic associations are directed at restraining their intake. Recently, it was found that relatively automatic evaluations of food were determined by the environment (Roefs et al., 2005); the stronger obese people were craving for food, the stronger their preference for palatable foods was. Whether obese people's early associations are disinhibition related (rather than restraint related) in situations that elicit craving, remains to be examined. As yet, the most obvious leason for obese people to overeat despite restraint associations is that 
they can simply not resist the temptation of tasty foods. They know that they should not eat too much, but they are not able to control their eating impulses. Recently, evidence was found for the hypothesis that obese people have difficulties controlling all their impulses (Nederkoorn, Braet, Van Eijs, \& Jansen, 2004). In particular the eating impulses might easily override the early restraint associations.

In sum, the present data show that, during early cognitive processing, palatable foods are associated with restraint rather than with disinhibition, in both obese and normal weight people. The fact that palatable foods do not automatically elicit dysfunctional disinhibiting thoughts but rather restraint related concepts in obese people is interesting. The present data suggest that obese people do not differ from normal weight people in the early processing of food related information.

\section{APPEndix: STIMULi}

\section{Study 1 and 2}

Palatable food word's. Chocolade (chocolate), chips (chips), friet (fries), croissant (croissant), pizza (pizza), roomijs (ice cream), magnum (magnum), taart (pie), cake (cake), hamburger (hamburger), oliebol (doughnut ball), koek (cookie)

Neutral words A (living room). Kast (closet), bankstel (lounge suit), krukje (stool), kapstok (hat stand), poef (hassock), salontafel (coffee table), lamp (lamp), boekenrek (bookshelf), sofa (sofa), rolluik (roll-down shutter), ladenkast (dresser), deurmat (doormat)

\section{Study 1}

Disinhibition words. Onbeheerst (unrestrained), vreten (to grub), controleverlies (loss of control), vreetbui (eating binge), volstouwen (to gorge), vraatzucht (gluttony), volproppen (to stuff), vollstoppen (to cram), vreetparti) (blowout), proppen (to shovel), eetbui (binge), doorslaan (breakdown)

Neutral word's B (office). Balpen (ballpoint), bladzijde (page), tekstverwerker (word processor'), plakband (sellotape), potlood (pencil), liniaal (ruler), agenda (agenda), beeldscherm (computer screen), printer (printer), nietmachine (stapler), perforator (perforator), inktpatroon (cartidge)

\section{Study 2}

Restraint words. Vet (fat), dik (big), afblijven (leave alone), slecht (bad), onverstandig (foolish), calorierijk (high-calorie), lijnen (slim), dieet (diet), kilo (kilo), vermijden (avoid), verboden (forbidden), verkeerd (wrong)

Neutral words B (office). Balpen (ballpoint), bladzijde (page), inkt (ink), plakband (sellotape), potlood (pencil), liniaal (ruler), agenda (agenda), beeldscherm (computer screen), computer (computer), letter (letter), papier (paper), pen (pen) 


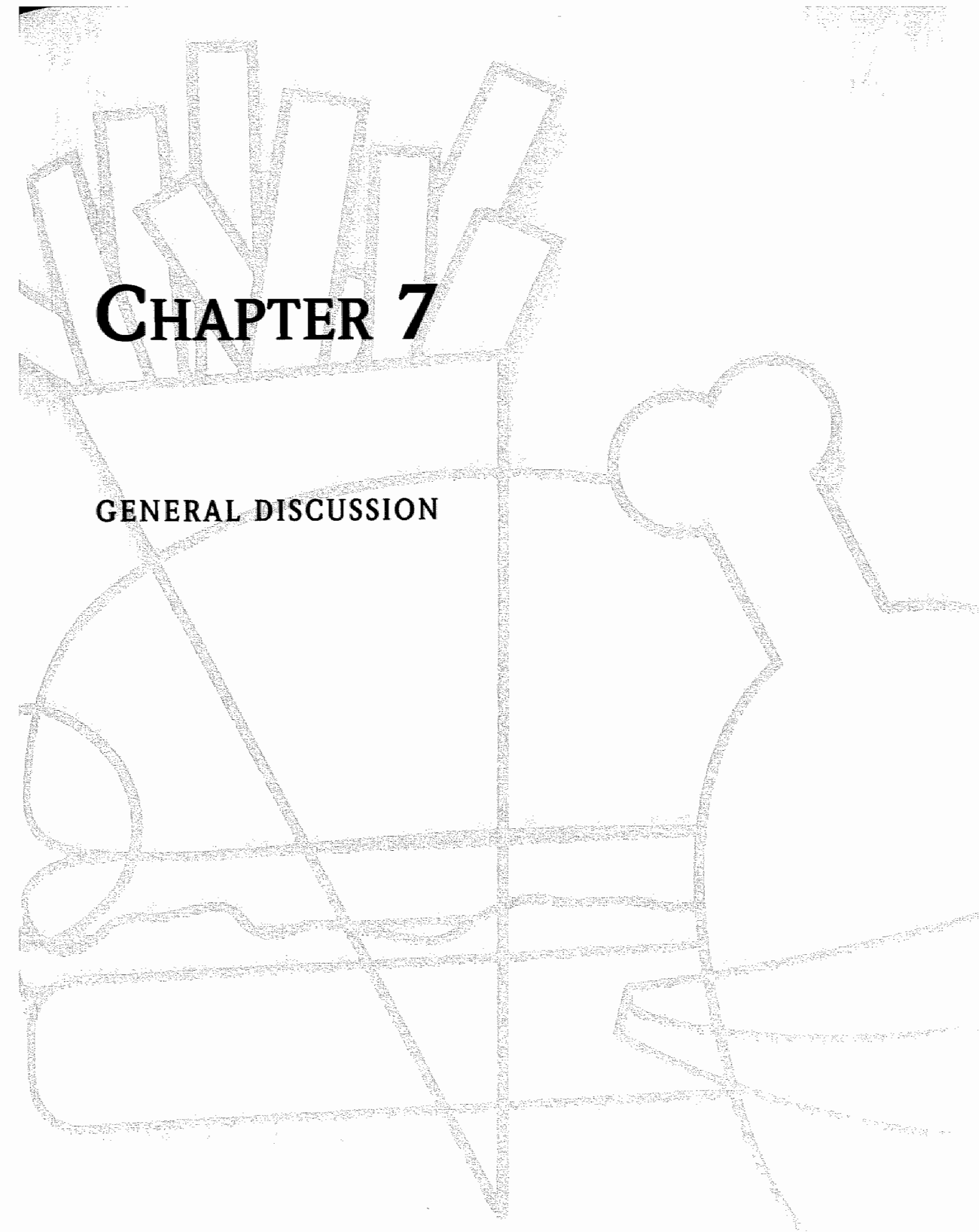


Chapter 7 
The main goal of the present thesis was to test whether adding cognitive therapy to the behavioral treatment of obesity promotes weight loss and prevents weight regain. Five studies were presented that all, more or less directly, contributed to this central goal. Below, a summary of the data will be given, followed by the main conclusions, methodological issues, suggestions for further research, and implications for clinical practice.

\section{SUMmaRY OF THE DATA}

The present thesis started with two studies conducted in the dietary practice. In our first study, the hypothesis was tested that a regular dietary treatment, that is primarily directed at decreasing weight, will also decrease concerns about shape, weight and eating, reduce binge eating, and improve mood and self-esteem (Chapter 2). Dietary treatments in field settings mostly focus on weight reduction and do not specifically touch on psychological variables. However, several studies found obesity to be correlated with psychological problems such as concerns about appearance, depressive symptoms, a low self-esteem, and binge eating (e.g., Johnsen, Gorin, Stone, \& Le Grange, 2003; Musante, Costanzo, \& Friedman, 1998; Quinn \& Crocker, 1999; Wilfley, Schwartz, Spurrell, \& Fairburn, 2000). Possibly, weight reduction is accompanied by improvements on these psychological measures as well. Because dietary treatments in field settings are often provided in groups but also individually, it was also tested whether group and individual treatment were equally effective. Although there was no specific attention for psychological. variables in the dietary treatment, the results showed that - overall - participants were less concerned about weight, had higher self-esteem, and had a less depressed mood after treatment. in reducing concerns about eating and shape, the group treatment was more effective than the indiwidual treatment. Although these data revealed benefits of the dietary treatment on the psychological level, it remained unclear whether anticipated relapses of weight will result in undoing the psychological advantages as well. The data furthermore showed that weight loss was accompanied by increased eating restraint in the group treatment. However, restraint theory's assumption that restraint leads to binge eating (Polivy \& Herran, 1985; 1993) was not supported by the data. Contrary to the prevailing opinion that dieting might cause eating disorder symptoms (e.g., binge eating) and should therefore be discouraged, the results of our first study suggest that dieting in a healthy way might instead be encouraged, especially in overweight and obese people. For the majority of obese people, it is the only way to lose weight.

In our second study (Chapter 3), characteristics of obese people registering for weight loss treatment by a dietician were studied. In a variety of disorders, comorbid depression was found to increase morbidity (Mendlewicz, 1998) and to worsen treatment outcome (Abramowitz \& Foa, 2000; Overbeek, Schruers, Vermetten, \& Griez, 2002/. The role of comorbid depressive symptoms in the treatment of obesity, however, is less clear. In the second study of this thesis, the relation between depressive symptoms on the one hand and specific eating psychopathology and self-esteem on the other hand was investigated. It was hypothesized that overweight and 
obese people with mild to moderate depressive symptoms would have more shape, weight and eating concerns, score higher on restraint, have lower self-esteem and have a higher BMI than overweight and obese people without depressive symptoms. Furthermore, it was hypothesized that in the group with depressive symptoms, more people would report binge eating than in the non-depressed group. Our hypotheses were supported by the data. Moreover, the data showed that - strikingly - about half of the participants that registered for dietary treatment scored ten or more on the BDI. It was concluded that for dieticians treating overweight and obese people, it is important to acknowledge depressive symptomatology in their patients.

The third study of this thesis (Chapter 5) was conducted to address a main problem to the standard behavioral treatment of obesity: its ineffectiveness in the long term le.g., Garner \& Wooley, 1991). We developed a new cognitive behavioral treatment for obesity (see Chapter 4 for a description of the treatment protocoll, and hypothesized that $1 /$ the cognitive behavioral treatment (CBT) would be more effective in reducing concerns about shape, weight and eating, binge eating, and depression and in improving self-esteem than a standard behavioral treatment (SBT) and that 2) weight losses would be maintained better after CBT than after SBT. Both treatments aimed to produce long term maintainable weight losses by changing dietary patters. Furthermore, CBT aimed at changing dysfunctional cognitions about eating, weight and shape and self-schemas, whereas SBT used physical exercise. The one year follow-up results showed that - as hypothesized - weight losses were maintained after CBT but not after SBT. Moreover, CBT was more effective in reducing concerns about eating and weight in the analyses by intention to treat. In line with the findings of our first study, the data furthermore showed that restraint scores increased after treatment while binge eating decreased. This was still the case one year after treatment ending. Again, the assumption of restraint theory that restraint leads to binge eating (Polivy \& Herman, 1985; 1993) was not supported by the data. For the subgroup of participants that were mildly to moderately depressed, the effects of CBT were even more prominent. The finding that CBT prevented relapse is encouraging for obesity treatment. It was concluded that adding cognitive therapy to the regular treatment for obesity by dieticians would be important in optimizing these treatments.

The cognitive model of obesity (see Chapter 4) assumes that dysfunctional cognitions about eating, weight and shape play an important role in the maintenance of obesity. The results. presented in Chapter 5 showed that a treatment that changed those dysfunctional thoughts. resulted in maintained weight loss. This, however, is no proof of the validity of the cognitive model. The final two studies of this dissertation were directed to experimentally test part of the model (Chapter 6). The first study tested the hypothesis that concepts of disinhibition and palatable foods are related on a relatively automatic cognitive level, particularly in the obese. The semantic priming paradigm was used to test this hypothesis. The hypothesized relation between disinhibition and palatable foods was, however, not found. Possibly, this association was not found because early associations with palatability are already directed at the unhealthy consequences of the high-fat palatable foods. Therefore, these foods might have elicited restraint 
associations instead of disinhibition associations. This hypothesis was tested in a second study, within the same paradigm. As hypothesized, the data of study 2 showed that the presentation of palatable food words facilitated the accessibility of restraint concepts. There were no differences between obese people and people of normal weight. It was concluded that both obese and normal weight people's early associations. with palatability are directed to restricting intake, rather than to disinhibition.

\section{Conclusions}

Four main conclusions can be drawn from the research in this thesis:

1. CBT prevents weight relapse in obesity treatment. Although the interaction of interest was marginally significant in some analyses, this conclusion was at least strongly suggested by the results of Chapter 5 . In this chapter, it was shown that a treatment that changes both dietary patterns and cognitions about eating, weight, and shape succeeded in achieving long term maintainable weight loss (i.e., one year after treatment ending) while a standard treatment that changed dietary patterns and used physical exercise did not. The finding that cognitive therapy had long lasting effects had also been reported for the treatment of depression (Fava et al., 2004; Hensley, Nadiga, \& Uhlenhuth, 2004). Although little is known about the precise working mechanism of CBT (Wilson, Fairburn, Agras, Walsh., \& Kraemer, 2002), it might tentatively be suggested that changing cognitions is important for weight maintenance to take place.

2. About half of the overweight/ obese people registering at a dietician for a weight problem scored ten or more on the BDI, indicating that they were mildly to moderately depressed (Beck, Steer, \& Garbin, 1988) (Chapters 3 and 5). These mildly to moderately depressed people suffered more than their non-depressed counterparts, and not only from their depression. They were more concerned about shape, weight and eating, scored higher on restraint, had more eating binges, a lower self-esteem and a higher BMI /Chapter 3 ). Strikingly, for those mildly to moderately depressed obese people, the benefits of CBT were even more prominent (Chapter 5). Apparently, overweight and obese people with depressive symptoms form a subgroup that is $1 /$ common in regular community dieticians' practices and 2) specifically well treated by cognitive therapy.

3. Restraint theory posits that dieting precedes binge eating (Poliwy \& Herman, 1985; 1993 ). The data in the present thesis, however, showed the opposite. In line with the findings of previous research (Presnell \& Stice, 2003; Stice, 2002) the data revealed that restraint scores increased after treatment, while eating psychopathology (1.e., concerns about shape, weight and eating, and binge eating) decreased (Chapters 2 and 5). One year after treatment, these results for binge eating were maintained (Chapter 5). Thus, changing dietary patterns resulted in increased restraint and at the same time in decreased eating psychopathology. Logically, obese people need to restrain their eating behavior in order to learn a healthy 
eating pattern and to lose weight. Interestingly, this "healthy dieting" did not lead to increased binge eating. Contrary to the prevalling opinion that dieting causes binge eating, the present data showed that in overweight and obese people, dieting in a healthy way might instead be encouraged.

4. No evidence was found for an early cognitive association between the concepts of palatable foods and disinhibition. In contrast, early associations with palatability are directed to restricting intake in both normal weight and obese people (Chapter 6 ).

The findings reported in Chapter 6 did not provide evidence for an association between palatable foods and disinhibition on an early cognitive level. Instead, relatively automatic associations to palatable foods were restraint-related in both obese and normal weight people. If early associations to palatable foods are already related to restraining intake, why then do obese people still eat more than is good for them? Other factors might cause the obese person to overeat despite the palatability - restraint associations. For example, recent research showed that obese people have difficulties controlling their impulses (Nederkoorn, Braet, Van Eijs, \& Jansen, 2004). In particular the eating impulses may easily override the restraint cognitions.

In Chapter 2, a study was presented that reported on the effectiveness of a regular dietary treatment - carried out by dieticians - on specific eating psychopathology, mood and selfesteem. From these data it was concluded that a regular dietary treatment - without psychological intervention - resulted in positive effects on these psychological parameters. Does this mean that diet management is sufficient in effectively improving psychological well-being? Or will weight regain undo the psychological advantages as well? The data presented in Chapter 5 showed that a cognitive behavioral treatment and a standard behavioral treatment did equally well on psychologicall measures (i.e., eating psychopathology, mood and self-esteem) in the short term. One year after treatment, CBT was more effective in reducing concerns about eating and weight than SBT in the intention to treat analyses. Moreover, CBT was superior to SBT in preventing weigh regain. Clearly, the cognitive intervention is prophylactic by preventing the usual weight regain after behaviorai treatment. In the treatment of depression, cognitive (behavioral) treatments are also known for their long term effectiveness and prophylactic effects (Fava et al., 2004; Hensley et al., 2004). It is a highly interesting finding that a cognitive intervention is so successful in obesity treatment. Future research should concentrate on the question why a cognitive intervention is effective in the prevention of weight regain after treatment.

\section{Methodological issues}

Three of the five studies presented in this thesis were conducted in the field. They were carefully designed, but some methodological limitations that were associated with their practical nature need to be discussed. 
Before discussing the limitations of (this) field research, it is important to notice that this type of research has its benefits. First, by testing our intervention in a relevant community setting, the generalizability of our findings will be increased (Goodwin, 1995). Participants were recruited by advertisements in local newspapers that asked for overweight people wanting to lose weight, and through the registration system of the dieticians department of the "Groene Kruis Zorg" [Green Cross Care]. It is therefore likely that our sample represented a rather general population of treatment seeking obese people. Of course, within the general population of obese people, treatment seekers in themselves are a selective group, and generalization of the results may therefore only be valid for obese treatment seeking people. Second, our new cognitive treatment was protocollized and added to standard behavioral treatment provided by dieticians. The program was tested in the field and in close cooperation with dieticians, cognitive behavioral therapists and physiotherapist. By protocollizing the treatment and by conducting the research in a relevant practical setting, its chances for implementation were optimized (e.g., Bartholomew, Parcel, Kok, \& Gottlieb, 2001; Rogers, 1983; 1995).

One of the difficulties we encountered in the large treatment effectiveness study (Chapter 5) was the inflow of participants. Because enlistment for the treatment was just enough to fill the groups, we were not able to follow a no-treatment control group. Short term results of the treatment were similar for the cognitive treatment and the standard treatment: participants improved on all psychological measures and weight. Because the lack of a no-treatment control group in that study, it is not certain whether these positive effects of time reflect a pure effect of treatment. However, previous research has shown that (cognitive) behavior treatments are superior to no-treatment control groups in the treatment of bulimia nervosa and binge eating disorder (e.g., Agras et al., 1995; Eldredge et al., 1997; Marcus, Wing, \& Fairburn, 1995; Peterson et al., 1998; Telch, Agras, Rossiter, Wilfley, \& Kenardy, 1990; Wilfley et al., 1993). Furthermore, the finding that participants had a lower BMI one year after treatment than before treatment is clinicaliy significant in itself, as time trend studies show that the prevalence of obesity increases with age (e.g., Visscher, Kromhout, \& Seidell, 2002).

Twenty-one percent of the participants did not complete treatment /Chapter 5 ), and $40 \%$ did not complete the study at the one-year follow-up. Although these percentages may seem high, they are comparable to those reported in related studies about dieting (e.g., Dansinger, Gleason, Griffith, Selker, \& Schaefer, 2005) and therapy effectiveness in bulimia nervosa patierits (e.g., Agras, Walsh, Fairburn, Wilson, \& Kraemer, 2000). Evidently, it is realistic for the clinical practice of dieticians to take into account that one in every five treatment starters does not complete treatment. Because in our study treatment dropout was defined as attending five or less treatment sessions, this means that one in every five participants did not even attend more than half of the sessions. These dropouts do consume time and effort of the therapist or dietician. Analyses by intention to treat - in which the dropouts are included - may therefore reflect those treatment effects that can be obtained in everyday practice. The analyses based on complete cases, on the other hand, reflect the effects of treatment for the subgroup that completed the treatment. 
Cognitive techniques are not easy to perform, and cognitive therapy needs to be carried out by specialized cognitive behavior therapists (Bögels, 1999). However, not much CBT therapists are specialized in the treatment of obesity (yet). Implementing CBT for obesity would have to hold thorough training of therapist into the protocol. Furthermore, treatment by psychotherapists is more expensive than that by dieticians, which needs to be considered before implementation. Before implementing this treatment on a large scale, it should be further investigated whether specific subgroups in particular benefit from the treatment.

Mild dy to moderately depressed obese people suffer more than their non-depressed counterparts; and not only from their depression (Chapter 4). Moreover, those participants who score ten or more on the BDI benefit strongly from the cognitive treatment. For dieticians, the BDI could be used as an easy and helpful tool to select and refer overweight people with depressive symptoms to an appropriately trained CBT therapist.

During the course of this $\mathrm{PhD}$ project, both dieticians and psychotherapists repeatedly showed interest in the study. For both disciplines, it seems that obesity kind of "falls between two stools". Dieticians are not trained to treat psychological problems, and they do not know where to refer to those obese people who need more. For cognitive behavior therapists, obesity is often seen as a problem that falls without their expertise, as they are primarily directed to treating psychopathology. Possibly, introducing both dieticians and CBT therapists to the cognitive treatment protocol, training of CBT therapists into this protocol, and setting up cooperation between local dieticians' centers - like the "Groene Kruis Zorg" - and mental health centers (RIAGGS) might bridge this gap. 
General discussion 
, ?,-

$\therefore \quad$ a 


\section{SUMMARY}

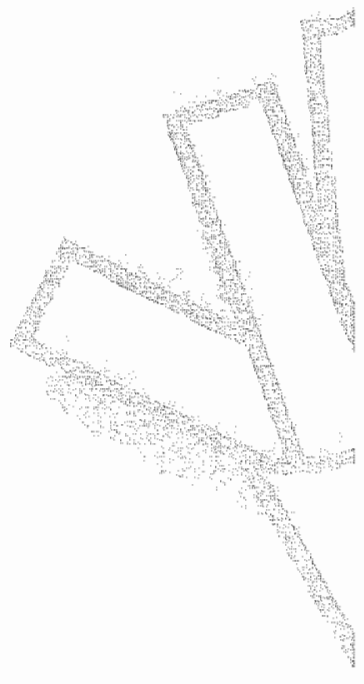


The prevalence of obesity has increased to epidemic proportions (WHO, 2000) in recent years. In the Netherlands, about $11 \%$ of the people is obese (BMI $>30)$ and another $35 \%$ is pre-obese (BMI 25-30) (CBS, 2005). This means that in total, $46 \%$ of the Dutch population is overweight (BMT > 25). Obesity has been associated with health problems on the physiological (e.g., cardiovascular diseases, diabetes) as well as on the psychological (e.g., concerns about appearance, binge eating, a depressed mood and low self-esteem) level (e.g, Johnsen, Gorin, Stone, \& LeGiange, 2003; Musante, Costanzo, \& Friedman, 1998; Ouinn \& Crocker, 1999; Visscher \& Seidell, 2001; Wilfley, Schwartz, Spurrell, \& Fairburn, 2000 1.

Treatments for obesity include bariatric surgery, pharmacological treatments and behavioral treatments. The long-term efficacy of surgery has been proven (e.g., Sjoström et al., 2004), but only for a selected subgroup of the obese. Moreover, the operation is not always successful $30 \%$ of the surgery patients regains weight within 2 years after the surgery - and in about $30 \%$ of the patients, complications arise (Hsu et al., 1998). Weight reduction medicines produce modest weight losses of nearly $10 \%$, but just for the time that the medication is used 1 Bray, 2000). Behavioral programs for obesity typically focus on weight loss through the reduction of energy intake and the stimulation of physical exercise. In the short term, traditional behavioral programs produce weight losses of about 9\% (Wadden, Sarwes, \& Berkowitz, 1909). However, a main problem to this treatment is its ineffectiveness in the long run: within 1.5 years, most. people return to their baseline weight (e.g., Garner \& Wooley, 1991; Wilson, 1994).

Recently, cognitive behavioral programs were proposed to improve the effectiveness of behavioral treatments (Cooper \& Fairburn, 2001; Nauta, Hospers, Kok, \& Jansen, 2000). Next to a behavioral component that addresses eating behavior, these programs consist of a cognitive component addressing cognitions. Dysfunctional cognitions are assumed to play a significant role in disturbed eating behavior (e.g., Cooper \& Fairburn, 1992) and obesity (e.g. Nauta, Hospers, Jansen, \& Kok, 2000). Moreover, cognitive behavioral treatments were shown to be effective in the treatment of eating disorders, such as bulimia nervosa (e.g., Wilson, 1999) and binge eating disorder (e.g., Agras, Telch, Arnow, Eldredge, \& Marnell, 1097; Nauta, Hospers, Kok, el. al., 2000\%. Importantly, these effects of CBT in bulimia nerwosa patients are usually well maintained (e.g., Wilson, 1999). Possibly, adding cognitive therapy to the behavioral treatment for obesity may result in maintenance of the weight loss that is reached by behavional treatments. The main goal of the present thesis is to test whether adding cognitive therapy to the treatment of obesity promotes weight loss and prevents weight regain. In the Netherlands, dieticians are best accessible health care practitioners for overweight and obese people seeking weight loss treatment. The effectiveness of weight reduction programs, however, is tarely studied in the field. To increase the ecological validity of our findings, our main hypothesis was tested in a relevant field setting: the "Groene Kruis Zorg" IGreen Cross Care], a Dutch organization of prevention and homecare that offers dietary treatments provided by dieticians.

First, two studies were conducted to gain a clear insight in 1) the effectiveness of regular dietary treatments in a field setting (Chapter 2) and 2) the psychological charackeristics of the 
overweight population that registers for such treatments (Chapter 31. In Chapter 2, it is questioned whether a regular dietary treatment for obesity that is primarily directed at decreasing weight, also influences concerns about shape, weight and eating, binge eating, mood and self-esteen, without a psychological intervention. It was furthermore tested whether a treatment provided in groups was clinically comparable to an individual treatment. The results showed that overall-participants were less concerned about weight, had higher self-esteem, and had a less depressed mood after treatment. The group treatment was more effective than the individual treatment in reducing eating- and shape concerns. The data furthermore showed that weight loss was accompanied by increased eating restraint in the group treatment. Notably, restraint theory"s assumption that increased restraint leads to increased binge eating (Polivy \& Herman, 1985 ; 1993) was not supported by the data. Contrary to the prevalling opinion that dieting might cause eating disorder symptoms (e.g., binge eating) and should therefore be discouraged, the results of our first study suggest that dieting in a healthy way might instead be encouraged, especially in overweight and obese people.

Chapter 3 presents a study in which characteristics of overweight and obese people attending the local Green Cross Care centre to lose weight were investigated. It was hypothesized that overweight and obese people with a mild to moderate amount of depressive symptoms would have more shape, weight and eating concerns, score higher on restraint, have lower self-esteem and have a higher BMI than overweight and obese people without depressive symptoms. Furthermore, it was hypothesized that in the group with depressive symptoms, more people would report binge eating than in the non-depressed group. Our hypotheses were supported by the data. Moreover, the data revealed that about half of the participants that registered for a dietary treatment suffered from a mildly to moderately amount of depressive symptoms. It was concluded that for dieticians treating overweight people, it is important to acknowledge depressive symptomatology in their patients.

The third study of this thesis addressed a main problem to the standard behavioral treatment of obesity: its ineffectiveness in the long term (e.g., Garner \& Wooley, 1991). In Chapter 4, a cognitive model for the maintenance of obesity and a cognitive treatment for obesity - derived from this model - are introduced. Chapter 5 reports on the effectiveness of the new cognitive behavioral treatment for obesity. In this study, it was hypothesized that I] the cognitive behavioral treatment (CBT) would be more effective in reducing concerns about shape, weight and eating, binge eating, and depression and in improving self-esteem than a standard behavioral treatment (SBT) and that 2) weight losses would be maintained better after CBT than after SBT. Both treatments aimed to produce weight loss by changing dietary patters. Furthermore, CBT aimed at changing dysfunctional cognitions about eating, weight and shape and self-schemas, whereas SBT used physical exercise. The one year follow-up results showed that - as hypothesized weight losses were maintained after CBT but not after SBT. Moreover, CBT was more effective in reducing concerns about eating and weight in the intention-to-treat analyses. In line with the findings of our first study, the data furthermore showed that restraint scores increased after 
treatment while binge eating decreased. This was still the case one year after treatment ending. For the subgroup of participants that were mildly to moderately depressed, the effects of CBT were even more prominent. The finding that CBT prevented relapse is encouraging for obesity treatment. It was concluded that adding cognitive therapy to the regular treatment for obesity by dieticians would be important in optimizing these treatments.

Chapter 6 presents the findings of two experimental studies, conducted to experimentally test part of the cognitive model of obesity (Chapter 4). In the first experiment, it was hypothesized that concepts of disinhibition and palatability are associated on a relatively automatic level, particularly in the obese. The hypothesized relation between disinhibition and palatable foods was, however, not found. Possibly, this association was not found because early associations with palatability are already directed at the unhealthy consequences of the high-fat palatable foods. Therefore, these foods might have elicited restraint associations instead of disinhibition associations. This hypothesis was tested in a second experiment. As hypothesized, the data of experiment 2 showed that palatability was associated with restraint. There were no differences between obese people and people of normal weight. It was concluded that both obese and normal weight people's early associations with palatability are directed to restricting intake, rather than to disinhibition.

Chapter 7 provides the reader with a general discussion of the findings. First, an overview of empirical findings and the main conclusions are given. Next, methodological issues, suggestions for further research, and recommendations for clinical practice are given.

In conclusion, the present thesis supports the hypothesis that adding a cognitive intervention improves the effectiveness of the standard behavioral treatment for obesity: as hypothesized, CBT prevented weight regain whereas SBT did not. Moreover, for obese people with a mildly to moderately amount of depressive symptoms, the benefits of $\mathrm{CBT}$ were even more prominent (Chapter 5). The data presented in this thesis furthermore show that in overweight and obese people, dieting in a healthy way might be encouraged. No support for the prevaling opinion that dieting leads to binge eating was found. In contrast, restraint increased after treatment, while eating psychopathology (including binge eating) decreased. Altogether, the present thesis shows that adding cognitive therapy to the behavioral treatment for obesity prevented weight regain. For dieticians and other health care providers offering (behavioral) weight loss programs for overweight and obese people, this finding is of great value. By cooperating with trained cognitive therapists, the effectiveness of their behavioral treatments may be improved. 


\section{SAMENVATTING}


De prevalentie van obesitas is de laatste jaren zodanig gestegen dat wel gesproken wordt van een epidemie (WHO, 2000). Recente cilfers laten zien dat ongeveer $11 \%$ van de Nederlandse bevolking obees (BMI > 30), en 35\% pre-obees is (BMI 25-30) (CBS, 2005). In totaal kampt dus $46 \%$ van de Nedemlanders met overgewicht (BMI > 25). Obesitas gaat waak gepard met lichamelijke klachten, zoals hart- en vaatziekten en diabetes, en met psychologische problemen, zoals zorgen over het uiterlijk, eetbuien, depressie en een lage zelfwaardering (bv., Johnsen, Gorin, Stone, \& LeGrange, 2003; Musante, Costanzo, \& Friedman, 1998; Ouinn \& Crocker; 1999; Visscher \& Seidell, 2001; Willey, Schwartz, Spurrell, \& Fairburn, 2000).

Voor overgewicht en obesitas zijn er verschillende yormen van behandeling, waaronder maag. werkleiningsoperaties, gewichtsreducerende medicijnen en gedragstherapie. Hoewel maagverkleiningsoperaties goede resultaten boeken op de lange termijn (Sjoström et al., 2004), zijn ze lang niet altijd succesvol: $30 \%$ van de patiënten wordt weer dikker binnen 2 jaar na de operatie, en ongeveer $30 \%$ van de patiènten ondervindt complicaties (Hsu et al., 1998). Bovendien komt slechts een selecte subgroep van de mensen met obesitas in aanmerking voor een maagverkleining. Met gewichtsreducerende medicijnen kan een gewichtsverlies van ongeveer $10 \%$ worden bereikt, maar meestal blijft dit gewichtsverlies alleen gehandhaafa gedurende de tijd dat het medicijn wordt gebruikt (Bray, 2000). Gedragstherapeutische programma's tenslotte, richten zich op het reduceren van de energie inname en het stimuleren van beweging. Op de korte termijn leiden traditionele gedragstherapeutische programma's tot een gewichtsverlies van ongeveer $9 \%$ (Wadden, Sarwer, \& Berkowitz, 1999). De lange termijn resultaten zijn echter uitermate teleurstellend; binnen 1 tot 5 jaar zijn de meeste patiënten weer terug op hun uitgangsgewicht (bv, Garner \& Wooley, 1991; Wilson, 1994).

Om de effectiviteit van gangbare gedragstherapeutische programma's te verbeteren, zijn recentelijk programma's ontwikkeld gebaseerd op cognitieve gedragstherapie [Cooper \& Fairburn, 2001; Nauta, Hospers, Kok, \& Jansen, 2000). Deze programma's richten zich niet alleen op eetgedrag, maar ook op het veranderen van cognities (denkpatronen). Disfunctionele cognities worden verondersteld een belangrijke rol te spelen bij het instandhouden van verstoord eetgedrag (Cooper \& Fairburn, 1992) en abesitas (Nauta, Hospers, Jansen, \& Kok, 2000). Cognitieve gedragstherapie is een effectieve behandeling voor eetstoomissen zoals bulimia nervosa (Wilson, 1999) en de eetbui stoornis (Agras, Telch, Arnow, Eldredge, \& Marnell, 1997; Nauta, Hospers, Kok, et al., 2000). Vooral belangrilk is, dat het gunstige effect van cognitieve gedragstherapie bij bulimia nervosa ook op de langere termijn behouden blijft (Wilson, 1999). Mogelijk kan het toevoegen van cognitieve therapie aan de gedragstherapeutische behandeling voor obesitas ervoor zorgen dat men het gewichtsverlies dat in eerste instantie wordt bereikt ook kan behouden. In dit proefschrift staat de vraag centraal of het toevoegen van cognitieve therapie aan de gangbare gedragstherapeutische behandeling voor overgewicht gewichtsverlies bevordert, en voorkomt dat men na afloop van de behandeling weer toeneemt in gewicht. Omdat de effectiviteit van gewichtsreducerende programma's nog niet vaak onderzocht is in veldsettings, en om de ecologische validiteit van onze bevindingen te vergroten, vond ons onderzoek plaats in een 
relevante praktische setting, namelijk bij de diêtisten van het Groene Kruis Zorg te Maastricht.

De eerste twee studies beschreven in dit proefschrift zujn opgezet om inzicht te verkrijgen in zowel de effectiviteit van een gangbare behandeling voor overgewicht door diëtisten (hoofdstuk 2) als in de psychologische kenmerken van mensen met overgewicht die een dergelijke behandeling zoeken (hoofdstuk 3). In Hoofdstuk 2 staat de vraag centraal of een gangbare diêtisten behandeling die primair gericht is op het bereiken van gewichtsverlies, ook effect heeft op de extreme bezorgdheid over eten, gewicht en uiterlijk, eetbuien, depressie en zelfwaardering, zonder dat hierbij gebruik gemaakt wordt van een psychologische interventie. Daarnaast werd onderzocht of een behandeling gegeven in groepsverband en een individuele behandeling even effectief zijn. Uit de resultaten van deze studie bleek dat de deelnemers na de behandeling minder bezorgd waren over hun gewicht, een hogere zelfwaardering hadden en zich minder depressief voelden dan ervoor. Op deze variabelen was er geen verschil tussen de individueleen de groepsbehandeling. De groepsbehandeling was wel effectiever dan de individuele behandeling in het reduceren van de bezorgdheid over eten en uiterlijk. Daarnaast bleek dat het gewichtswerlies in de groepsbehandeling gepaard ging met een toename van (gerapporteerd) lijngedrag. De in de vakliteratuur populaire aanname dat lijnen leidt tot eetbuien (Restraint Theory: Polivy \& Herman, 1985; 1993) werd door onze bevindingen niet gesteund. In tegenstelling tot de heersende opinie dat lijnen eetstoornissen zou veroorzaken, en dus ontmoedigd zou moeten worden, suggereren onze bevindingen juist dat lijnen op een gezonde wijze aangemoedigd zou moeten worden, vooral bij mensen met overgewicht.

In Hoofdstuk 3 worden vervolgens de resultaten gepresenteerd van een studie naar de (psychologische) karakteristieken van mensen met overwicht die hulp zoeken bij de diëtist. Wij verwachtten dat mensen met overgewicht én depressieve symptomen meer zorgen zouden hebben over eten, gewicht en uiterlijk, hoger zouden scoren op gerapporteerd lijngedrag, een lagere zelfwaardering zouden hebben en een hogere BMI zouden hebben dan mensen met overgewicht zonder depressieve symptomen. Daarnaast voorspelden wij dat in de groep met depressieve symptomen meer mensen eetbuien zouden rapporteren dan in de niet-depressieve groep. De bevindingen bevestigden onze hypotheses. Opmerkelijk was dat bijna de helft van de deelnemers aan deze studie last had van depressieve symptomen. Het is van groot belang dat diëtisten en andere behandelaars zich bewust zijn van een eventuele depressieve stemming bij hun cliënten. Mogelijk hebben deze "depressieve" cliënten baat bij een behandeling aangevuld met cognitieve therapie, waarvoor zij doorverwezen kunnen worden naar een psychotherapeut.

In de derde studie van dit proefschrift staat hetprobleem van de gangbare gedragstherapeutische behandelingen centraal: de ineffectiviteit hiervan op de lange termijn (bv., Garner \& Wooley, 1991]. Hoofdstuk 4 introduceert een cognitief model voor de instandhouding van obesitas en een nieuwe cognitieve behandeling, gebaseerd op dit model. Vervolgens worden in Hoofdstuk 5 de resultaten gerapporteerd van een studie naar de effectiviteit van deze nieuwe cognitieve gedragstherapie voor obesitas. Onze hypotheses waren dat 1) de cognitieve gedragstherapie effectiever zou zijn in het reduceren van bezorgdheden over eten, gewicht en uiterlijk, in het 
verminderen wan eetbuien en depressie, en in het verbeteren van de zelfwaardering dan een standaard gedragstherapeutische behandeling en dat 2) gewichtsverlies beter behouden zou blijven na cognitieve gedragstherapie dan na de standaard gedragstherapie. Beide behandelingen hadden tot doel gewichtsverlies te bereiken door middel van het veranderen van het eetpatroon. Daarnaast was de cognitieve gedragstherapie gericht op het veranderen van disfunctionele cognities over eten, gewicht en uiterlijk en schema's over de eigen persoon, terwijl deelnemers in de stamdaard behandeling gingen bewegen. Een jaar na het beëindigen van de behandeling bleek - zoals voorspeld - dat gewichtsverlies behouden bleef na cognitieve gedragstherapie, en niet na de standaard gedragstherapie. Bovendien bleek dat cognitieve gedragstherapie effectiever was in het reduceren van bezorgdheden over eten en gewicht [de intention-to-treat analyses]. Zoals wij reeds in de eerste studie (hoofdstuk 2 ) vonden, ging ook in deze studie een verhoogde score op gerapporteerd lijngedrag gepaard met een afname in eetbuien. Dit was ook nog het geval een jaar na het beëindigen van de behandeling. Vooral de subgroep van deeinemers met depressieve symptomen leek van de cognitieve gedragstherapie te profiteren. De bevinding dat cognitieve gedragstherapie voorkomt dat men na afloop van de behandeling weer aankomt in gewicht is bemoedigend. Het toevoegen van cognitieve therapie aan de gangbare diëtistenbehandeling levert dan ook een belangrijke meerwaarde.

In Hoofdstuk 6 worden twee experimentelle studies beschreven, uitgevoerd om aspecten van het cognitieve model vam obesitas (hoofdstuk 4) experimenteel te testen. In het eerste experiment toetsten wij de hypothese dat ontremming (het ongeremd innemen van voedsel? en smakelijkheid (lekkere voedingsmiddelen) al op een relatief automatisch cognitief niveau geassocieerd zijn, en voornamelijk bij mensen met obesitas. Wij konden de voorspelde relatie tussen ontremming en smakelijkheid echter niet aantonen. Mogelijk vonden wij deze relatie niet omdat automatische associaties met smakelijkheid al gericht zijn op de ongezonde consequenties van de vetrijke, lekkere voedingsmiddelen. Misschien associeerde men de lekkere voedingsmiddelen dus al op een vroeg niveau met het beperken van de inname, in plaats van met ontremming. Deze hypothese werd in een tweede experiment getest. Zoals voorspeid lieten de resultaten zien dat smakelijkheid inderdaad geassocieerd wordt met lijnen. Mensen met obesitas en mensen van normaal gewicht werschilden hier niet in. Blijkbaar zijn relatief automatische associaties met smakelijkheid, zowel van obesen als van mensen van normaal gewicht, al gericht op het beperken van de voedselinname, in plaats van op het ontremd innemen hiervan.

Hoofdstuk 7 biedt een algemene discussie van de in dit proefschrift beschreven studies en bevimdingen. Een samenvatting van de empirische bevindingen en belangrijkste conclusies wordt gevolgd door een bespreking van enkele methodologische kwesties. Tot slot worden suggesties voor toekomstig onderzoek en aambevelingen voor de praktijk gegeven.

Concluderend kunnen we zeggen dat het toevoegen van cognitieve therapie de effectiviteit van de gangbare gedragstherapeutische behandeling voor obesitas (gegeven door dietisten) verbetert. Immers, de resultaten beschreven in hoofdstuk 5 lieten zien dat cognitieve gedragstherapie 
voorkwarn dat men weer toenam in gewicht na de behandeling, terwill de standaard gedragstherapeutische behandeling deze terugval niet kon voorkomen. Bovendien leken de deelnemers met depressieve symptomen extra van de cognitieve gedragstherapie te profiteren. Daarnaast laten de bevindingen van dit proefschrift zien dat gezond lijnen aangemoedigd moet worden voor mensen met overgewicht; de hypothese dat lijnen lijdt tot eetbuien (Polivy \& Herman, 1985; 1993. werd door onze data niet ondersteund. In tegendeel, onze resultaten lieten juist zlen dat lijnscores hoger waren na de behandeling, terwijl eetpsychopathologie (inclusief eetbuien) afnam. Tot slot; de bevindingen uit dit proefschrift laten zien dat het toevoegen van een cognitieve interventie aan een gedragstherapeutische behandeling van obesitas voorkomt dat men na het beëindigen van de behandeling weer toeneemt in gewicht. Deze bevinding is van groot belang voor diëtistern en andere behandelaars van mensen met overgewicht. Samenwerking met cognitief therapeuten kan de effectiviteit van de gangbare gedragstherapeutische behandelingen op de lange termijn verbeteren. 


\section{REFERENCES}


Abramowitz, I. S., \& Foa, E. B. 2000 . Does major depressive disorder inhtence outcome of expocure and response prevention for OCD? Behawtor Therapys 31,705-800.

Agras, W. S., Telch, C. F, Amow, B., Eldredge, K., Detzer, M. J., Henderson, J, et al (1905). Does interpersonal therapy help patients whth binge eating disorder who fall to respond to cognitive heraph foumat of Consuting and Chical Psychology $03,356-360$.

Agras, W. S., Telch, C. F. Anow, B., Eldredge, K. \& Marnell, M. (1997). One-yeal follow-up of cognitivebehavioral therapy for obese individuals with binge eating disordex. Joumal of Consuling and chitcal Psycholog\%, 05, 343-347.

Agras, W. S., Telch, C. F, Amow, B., Eldredge, K. Wilfey, D. E. Raeburn, S. D. et al. (1904). Weight loss, cognitive behavioral, and desipramine treatments in binge eating disorder, an additive design. Behawor Therap, $25,225 \cdot 238$.

Agras, W. S., Walsh, B. T. Faiburn, C. G., Wilson, G. T. \& Kraemer, H. C. 2000 . A multicenter compartson of cognitiwe-behavioral therapy and interpersonal psychotherapy for bulimia nervosa. Archives of ceneral Psychath 57, 459-460.

American Psychatric Association (1994) Diagnosic and statistical manual of mental disorders, (df" ed. Washington, DC: APA, 1994.

Barsh, G. S., Farooqi., I. S. \& ORahily, 5. 20001. Genetics of body-weight regulation. Nature, 404, 044651.

Bartholomew, L. K. Parcel, G. S. Kok, G., \& Gottlieb, N. H. (2001). Intevention Mapping. Deslgning theoryand evidence based health pronotion programs (pp 200-319). Mountain view, Galiornia: Maylield Publishing Company.

Baucom, D. H., \& Aiken, P. A. 1 .98 Ij. Effect of depressed mood on eating among obese and nonobese diering and nondieting persons. Joumal of Rersonalty and Sochl PSychology. 4/,577-585.

Beck. A. T. (1976). Cognitwe therapy and he emotional disorders. New York: International Uniwersites Press. Beck. A. T., Steer, R. A. \& Garbin, M. G. (1988). Psychometric properties of the Beck Depression Inventon: Twenty five years of evaluation. Cinicar Psychology Revew, $8,77 \cdot 100$.

Beck, A. T. Ward, C. H., Mendelson, M., Mock, I. \& Erbaugh, , (1001). An inventory for measuring depression. Aromes of Cenerat Mychiary, 4, 561-571.

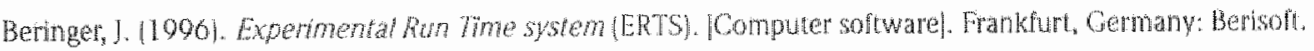

Beman, W. H. Berman, E. R. Heymsfield, S., Faucl, M. \& Ackernan, S. 110921 . The incidence and comorbidity of psychatic disorders in obesity. Jound of Personalin Dionders, $0,168.175$.

Blair, I. V. (2002). The malleability of atutomatic stereotypes and prejudice. Penowality and sochat pryoloby Review $0.242-201$.

Bogels, S. M. 11909]. Expertise in cognitieve therapie: waardigheden, training en supervisie. In S. M. Bögels \&

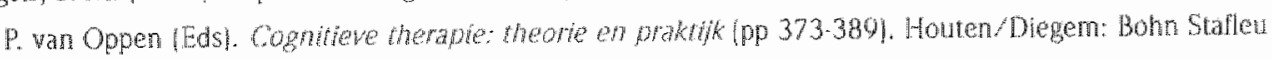
van Loghum.

Hoon, B., Stroebe, W. Schut, H., \& lansen, A. (1908). Food for thought: cognitive regulation of food intake. Britis Journat of Heath Bychology, 3, 27-40.

Bosson, J. K., Swann, W. B., \& Pennebaker, J. W. 2000 . Staking the perfect measure of implicit selfesteem: The blind men and the elephant revisited? Joumat of fersonality and Social Fswotogy, $70,031.043$. 
Bowen, D. J., Tomoyasu, N., Anderson, M., Carney, M. \& Kristal, A. [1902]. Effects of expectancies and personalized feedback on fat consumpton, taste and preference. Joumat of Apolied Socat Psychotogy, 22, $10011-1079$.

Bray, G. A. [1998). Contemporaly diagnosis and management of obesty. Newton: PA: Handbooks in Health Care.

Bray, G. A. 20001. A concise review on the therapeutics of obestity. Nitrition, 10,953960 .

Brolin, R. E, Roberson, L. B., Kenler, H. A., Cody, R. P. (1994). Weight loss and dietary intake after vertical: banded gasuroplasty and Roux.en-Y gastrc bypass. Annals of Swgery, 2200, 782.790.

Bruce, B. \& Agras, W. S. 11992 . Binge eating in females: a population based investigation. Intemational Joumal of Earing Disorders, $12,365.373$.

Cahil!, A. \& Lean, M. E. (1999). Review article: malnutrition and maltreatment-a comment on orlistat for the treatment of obesiy. Almentary Phamacology o Therapeutiss, 13,997-1002.

Cargih, B. R., Clak, M. M., Pera, V. Niaura, R. S. \& Abrams, D. B. (1099). Binge eating, body image, depression, and selfeffacy in an obese clinical population. Obesicy Research. $7,379-380$.

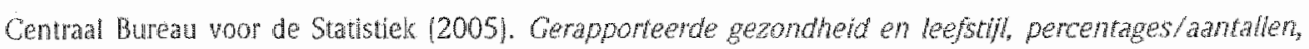
cotal kennerk gebuikers. Statine CBS: http//statine.cbs.nl/statweb

Charney, D. A., Parherakis, A. M, \& Gill, K. I. [2001). Integrated treatment of comorbid depression and substance use disorders. Fournal of Chincal Pychiaty; 02, 672.677.

Chua, ]. L., Touryz, S., \& Hill, A. 1. [2004]. Negative moodinduced overeating in obese binge eaters: an experimental study. Intemational Jounat of Obesity, $28,600-010$.

Clark, M. M. Nagura, R, King, T. K. \& Pera, V. (1996). Depression, smoking, activity level, and health status: Pretreatment predictors of attrition in obesily treatment. Addictive Behaviors, 21, 509.513.

Cohen, J. [1902). A power primer. Psychological Butletin, 112, 155-159.

Cooper, M. Cohen Tovée, E, Todd, G., Wells, A. \& Tovee, M. (1997). The earng disorder belief questionnaire: Preliminary development. Behaviou Research and Therapy, $35,381388$.

Cooper, M. 1.. \& Fairbum, C. G. 119921. Thoughts about eating, weight and shape in anorexia nerwosa and buimia nervosa. Behaviour Research and Thetam, 30, 501-511.

Cooper, Z., \& Fatbum, C. C. 2001 J. A new cognitive behavioural approach to the rreatment of obesity.

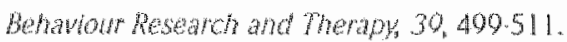

Crisp, A. H. \& McGuiness, B. (1970). Joly fat: relationship beween obesity and psychoneurosis in genemal population. BMf, $1,79$.

Dansinger, M. L., Geason. I. A. Grifith, I. L., Seker, H. P. \& Schaefes, F. J. 20057. Comparison of the Atkins, Omish, Weight Watchers, and Zone diets for weight loss and heart disease risk reducion: a randomized trial. JAMA, 293, 43-53.

De Houwer, J. (2002). The implicit association test as a toof for studying dysfunctional associations in psychopathology: strengths and limitations. Loumal of behawor Therapy and Expermental Psychatry. 33 , $115: 133$

De Howwer: ]. 20031. A structural analysis of indirect measures of atitudes. In ]. Musch \& K.C. Klaver [Eds?,

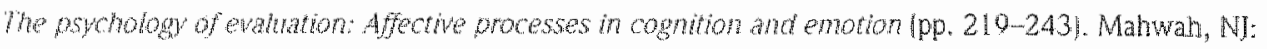
Lawence Entbrum Associates. 
De How wer, I. (in press). What are implicit measures and why are we using them? In R.W. Whers \& A.W. Stacy (Eds.1, The handbook of implicir cognitron and addicton, Thousands Oaks, CA: SAGE Publishers.

De Jong, P. I., Pasman, W. Kindt, M., \&an den Hout, M. A. (2001). A reaction time paradigm to assess

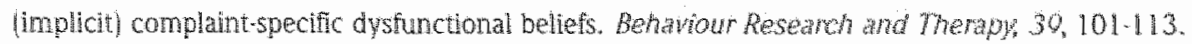

De Zwaan, M. * Mitchell, J. E. 11992/. Binge eating in the obese. Annals of Medicine, 24, $303-308$.

De Zwaan, M. Mitchell, J. E., Seim, H. C, Specker, S. M., Pyle, R. L., Raymond, N. C., et al. 119041. Eating related and general psychopathology in obese females with binge eating disorder. Intemational foumal of Eating Disorders, $15,43-52$.

Dong, C., Sanchez, L. E. \& Price, R. A. (2004). Relationship of Obesity to Depression: A Family based Study. International joumal of Obesty, $28,790.705$.

Drenowski, A. $\{1989)$. Sensory preferences for fat and sugar in adiolescence and aduit life. Anhals of the New York Acanemy of Sciences, $561,243 \cdot 250$.

Drenowski, A. (1991). Obesity and eating disorders: Cognitive aspects of food preference and food aversion. Bulletin of the Psychonomic Sartely, 20,261-264.

Drenowski, A. (1997). Taste preferences and food intake. Annual Reviews Nutrition, 77, 237-253.

Eidredge, K. L., Agras, W. S., Amow, B., Telch, C. F. Bell, S., Castonguay, L., et al. (1997). The effects of extending cognitive behavioral therapy for binge eating disorder among initial treatment nonresponders. Intemational Joumal of Eating Disorders, $21,347-352$.

Fairburn, C. G. \& Beglin, S. I. (1994). Assessment of eating disorders: Interwiew or sell-report questionnaire? Mnemational humal of Eating Disorders, 16, 303.370.

Fainburn, $G . G$, \& Cooper, Z. (1993). The Eating Disorder Examination (12th edition). In C. G. Farbun (Ed.). (1993). Binge eating: Nature, assessment, and treatment (pp. 317-300). New York, NY: Guilford Press.

Fairburn, C. G., Cooper, Z., \& Shafran, R. (2003). Cognitive behaviour therapy for eating disorders: A "transdiagnostic" theory and treatment. Behaviour Research and Therapy, 41,509-528.

Fairbum, C. G., Jones, R., Peveler, R. C., Carr, S. I. Solomon, R. A. O Connor, M. E, et al. (1991), Three psychological treatments for bulimia nervosa: A comparative trial. Archives of General Psychiatry. 48,463 . 409 .

Tainburn, C. G. Marcus, M. D. \& Wison, G. T. (1993). Cognitve Behavional Thelapy for Binge Eating and

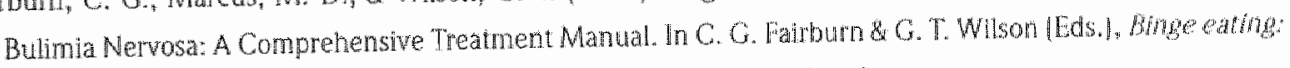
Nature, assessment and trealment (pp. 301-404). New York: Guilloid Press.

Fava, G. A., Ruini, C., Rafanelli, C. Fnos, L., Conti, S. \& Grandi, S. 2004). Six-Year Outcone ol Cognitive Behavion Therapy for Prevention of Recurrent Depression. American Joumat of Psychiaty; $101,1872-1876$.

Foster, G. D., Wadden, T. A., Vogt. R. A., \& Brewer, G. $(1997)$. What is a reasonable wreight loss? Patlents'

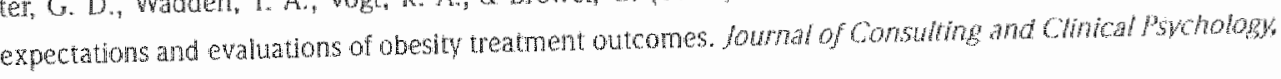
05, 79.85.

Friedman, M. A. \& Brownell, K. D. 119951 . Psychological correlates of obesity: Moving to the next research generation. Psychological Bulletin, $M, 3-20$.

Frost, R. O. Goolkasian, G. A., Ely, R. J., \& Blanchard, F. A. 119821 . Depression, restraint and eatng behavior. Behaviour Research and Therapy. 20,113-121. 


\section{References}

Garner, D. M. Wooley S. C. 19911 . Contronting the failure of behavoral and detary treatments for obesity. Chinat Psychology Rewew, $11,729.780$.

Gemar, M. C., Segal, Z, V. Sagrati, S., Rennedy, S. J. (200 H. Mood-Induced changes on the implicit association rest in recovered depressed patients. Jounal of Abnomal Psychology, 110,282 289.

Goodwin, C. J. (1999). Kesearch in pstchology mehods and design New York: John Wiley \& Sons, Inc.

Greenwald, A. G, Mcchee, D. E., Schwarti, I. L. K. (1098). Measuring individual differences in implicit cognition: The implicit association test. Joumal of Personality and Social Psychology, 74, 14641480.

Heatherton, T. F, Herman, C. P. Polivy, J. King, G. A. McGree, S. T. (1088). The (mis)measurement of restraint: An analysis of conceptual and psychometric issues. Joumal of Abnomal Psychology $97,19.28$.

Hedley, A. A., Ogden, C. L., Johnson, C. L. Carroll, M. D., Curtin, L. R. \& Flegal, K. M. (2004). Prevalence of overweight and wesity among US chidren, adolescents, and adults, 1909.2002. JAMA, 291, 28472850.

Hensley, P. L., Nadiga, D. a d Ulenhuth, E. H. (2004). Longterm effectiveness of cognitive therapy in major depressive disorder. Depression and Arxtety, 20, 1-7.

Herman, C. P., \&ack, D. [1975]. Restrained and unestrained eating. Journal of Personalty, 43, 647-660.

Hetman, C. P, \& Polww, I. [1 9801. Restraint eating. In A.J. Stunkard (Ed.), Obesto (pp. 208225). Philadelphia: Sauders.

Herman, C. P. \& Polivy, ) (1984). A boundary model for the regulation of eating. In A.J. Sunktard \& E. Stellar (Eds.), Eating and its disorders lpp. 141.1561. New York: Raven Press.

Hickiord, C. Wards, T., \& Bulik, C.M. (1997). Cognitions of restrained and unrestrained eaters under fasting and nonfasting conditions. Behawour Research and Therapy, 35,71.75.

Hill, J. O. \& Peters J. C. [1998). Environmental contributions to the obesity epidemic Science, 280, 1371-1374.

Hsu, L. K., G., Benoti, P. N. Dwyer. J., Roberts, S. B., Salzman, E., Shikora, S., et al. (1998). Nonsurgical factors that influence the outcome of bariatric surgery: a veview. Psychosomatic Medicine, 60,338-346.

Instutute of Medicine (1995). Weighing the optons: Critentat for evaluating weight management programs. Washington, DC: National Academy Press.

Isnard, P. Michel, G., Frelut, M. L., Vila, G., Falissard, B.. Naia, W, et al. (2003). Binge eaing and psychopathology in severely obese adolescents. Mnternational Jounal of Eathg Dsordas, $34,235.243$.

Jansen A. (1998). Gating Disotders. In: A.S. Bellack \& M. Hersen (Eds). Comprehensike Chicat Psychology Ipp. 040.007). Oxford: Elsewier Science Limited, Pergamon Press.

Jansen, A., Merckelbach, H., Oosterian, I., Tuiten, $A_{2}$ van den Hout M. (1988), Cognitions and selr-talk durng food intake of restrained and unrestrained eaters. Behavour Research and Therapy, 26, 3933998.

Jansen, A., Theurissen, N., Slechten, K. Nederkoom, C., Buon, B., Mulkens, S., et al. 2003). Overweight children overeat after exposure to food cues. Earth Behawors, 4, 197209.

Jansen, A, \& Van den Hout, M. 19911. On being led into temptation: "Counterregulation" of dieters after smelling a "prelod". Addictive Beharios: $10,247-253$.

Jefley. R. W., Epstein, L. H. Wison, G. T., Drewnowski, A., Stunkard, A. J., Wing, R. R., et al. (2000). Long. tem maintenance of weight loss: Current status. Heath Psychology 19 [Suppl. 1], 5-16.

Jeffery, R. W. Wing R. R., \& Mayer, R. R. 11998]. Are smaller weight losses or more achievable weight loss goals better in the long tem for obese patients? Jommat of Consuting and Cinical Pychology, 60, 641-645. 
Johnsen, L. A. P., Gorin, A., Stone. A. A., \& le Grange, D. (2003), Chanactetistic of binge eamganong women in the community seeking treament for binge eating on weight loss. Eatho Rehavors, 3205305 .

Johnson, M. R., \& Lydiard, R. B. (1998). Comoribioty of major deptession and panic disorder Joumat of Chowal Psychology, 54, 201-210.

Iorm, A. F, Korten, A. E., Christensen, H., Jacomb, P. A., Rodgers, B., \& Parsiow, R. A. (2003). Assochation of obesity with anxiety, depression and emotional well-being: a community survey. Alstratan and New Zealand loumal of Public Health, $27,4344440$.

Kalarchian, M. A., Wison, G. T., Brolin, R. E. \& Bradey, L. (1998). Binge eating in bariatric surgery pattents. International Journat of Eating Disonders, $23,89-92$.

Kalarchian, M. A., Wilson, G. T., Brolin, R. E., \& Bradley, L. (2000). Assessment of eatirg disorders in bariaric

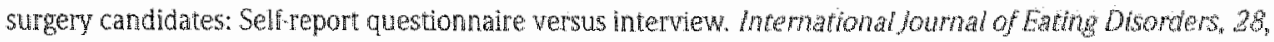
405-469.

Katz, D.L., Chan, W., Gonzalez, M. Larson, D., Nawaz, H. Abdulrahnan, M., et al. 120021. Technical skills for weight loss: preliminary data from a randomized trial. Preventive Medicine, $34,608.15$.

Kral, J. G. (1992). Surgical treatment of obesity. In P. Bjorntorp \& B. N. Brodoff (Eds.). Obesity (pp 731.741). Philadelphia: Lippincott.

Kral, J. G., Gortz, L., Hermansson, G. \& Wallin, G. S. [1993]. Gastroplasty for obesity: Long-tem weight loss improved by vagotomy. World Joumal of Sugery, $17,75,79$.

Luce, K. H., \& Crowther, ). H. (1999). The reliability of the Eating Disorder Examination-Seif-Report Questionnaire Version (EDE-O). International Joumal of Eating Disorders, 25, 349.351.

Marcus, M. D., Smith, D., Santelli, R., \& Kaye, W. (1992). Characterization of eating disordered behavior in obese binge eaters. Intemational Jounat of Eating Disorden, 12,249.255.

Marcus, M. D., Wing, R. R. F Fairbum, C.G. (1995). Cognitye behavioul treatment of binge eating ws behavioral weight control on the treatment of binge eating disorder. Anjals of Behaviond Medicine, 17 , 5090

Masheb, R. M, \& Grilo, C. M. (2000). Binge eating disorder: a need for additional diagnostic criteria. Comprehensive Psychiatry, 4l, $159 \cdot 102$

McElroy, S. L., Kotwal, R., Malhotra, S., Nelson, E. B., Keck, P. E. Ir, \& Neneroff, C. B. 20041. Are Mood

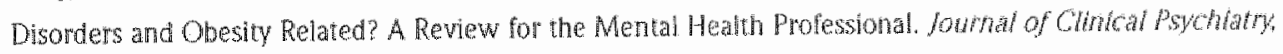
65. 634.651 .

Meiboom, A., \& Jansen. A. (1999), Cogntieve therapie bil eetstoomissen. In: S. M. Bögels \& P. wan Oppen: Cognilieve theraple: theorie en praktik (pp 277-303). Houten/Diegem: Bohn Stafleu wan Loghum.

Meijbom, A., Jansen, A., Kampman, M., \& Schouten, E. 11999. An experimental test of the relationship between selfesteem and concem about body shape and weight in restraned eaters. Inchathonal fownat of Eating Disorders, $25,327-334$.

Mendewicz, J. 1908). The broad spectun of comorbid depression: implications for treatment. European Pspchaty, 13,18.

Mokdad, A. H., Ford, E. S., Bowman, B. A., Dierz, W. H., Mnicol, F, Bales, V. S., et al. (2003). Prevalence of obesity, diabetes, and obesity telated heath risk factors, 2001 . JAMA, $289,76.79$. 


\section{References}

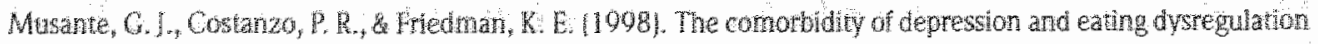

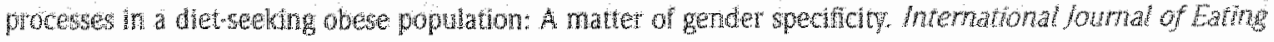
Disorders, $23,65.75$.

Natorial Institutes of Healn/ Natona Hearth, Lung, and Blood Instute 11998). Cinical gudelines on the Idenufficalion, evaluation and tratment of overweight and obesily in adults: The evidence report. Obesity Researh: o (Suppl), 52.210.

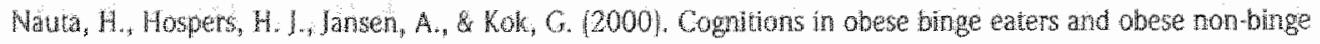
eaters. Cogintwe therapy and Researeh, $24,521-531$.

Matud, H. Hospers, H. Kok, G., \& Jansen, A. 120001. A comparison between a cognithe and behavioral treatrient for obese binge eaters and obese non binge eaters. Behavio Therapy, 31. 441.461.

Nederkoon, C., Brtet, C. Van Eils, Y. \& Jansen, A. (2004). Why abese chrdren can hot resist food: Impulsivity ats a sisk factor for obesity and an obstacle for treament. Manuscripi submitted for publication.

Nederkoom, C. Van Lijs, Y, \& Järsen, A. (2004). Restrained eaters act on impulse. Personality and howiwat Differences, $37,1651 \cdot 1058$.

Neely. J. H. 119771. Semantic priming and retrieval from lexical memory: Roles of inhibitionless spreading

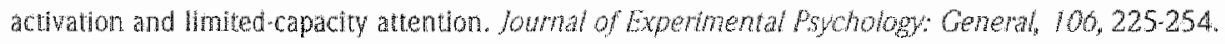

Neely, J. H. (1991). Semantic priming effects in visual word recognition: A selective review of current findings and theories. In D. Besner \&.W. Humphrews [Eds, Basic processes in reading: Visual word recognition (pp. 264-337). Hillsdale, NJ: Erlbaum.

Neumark-Sztainer, D., Rock, C. L., Thonnüst, M. D., Cheskin, L. I., Nethouser, M. L., Bamert, M. J. (2000). Weight-control behaviors among adults and adolescents: associations with dietary intake. Preventive Medicine, $30,381.391$.

Otson, M. \& Frzio, R. H. (2003). Relations between implicit measures of prejudice: What are we measuring? Psychological Science, 14,636039 .

Ouwens, M. A. van Strien, T. \& van der Stazk, C. P. F. \{2003). Tendency toward overeating and restraint as

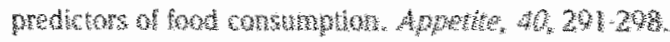

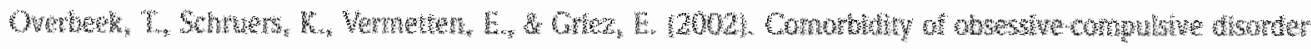

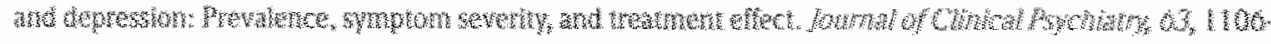
Hriz.

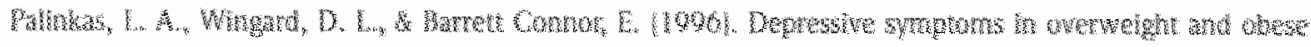

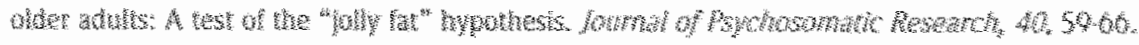

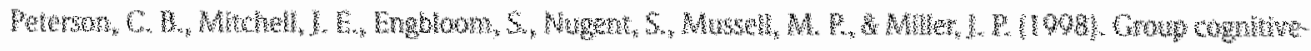

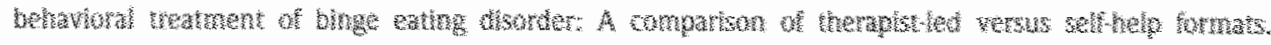

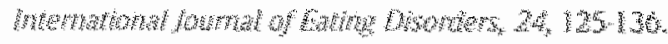

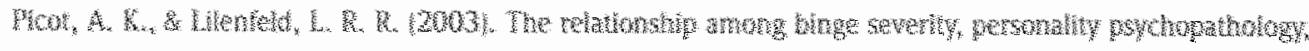

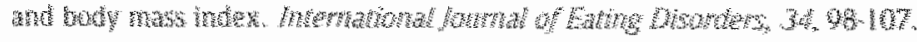

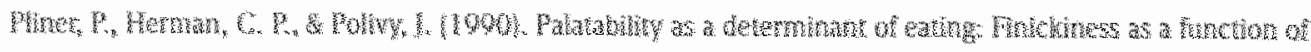

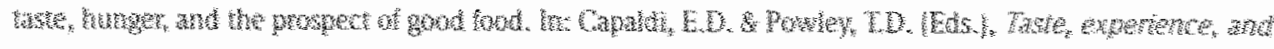

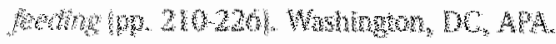


Poliw, I. (1976). Perception of calories and regulation of intake in restrained and unrestatined subjects. Addictwe Rehaviors, $1,237-243$.

Polvy, 1. \& Heman, C. P. (1985). Dieting and binging A causal analysis. American Bsychologist, 40, 193201.

Polivy, I. \& Herman, C. P. (1092). Undieting: A program to help people stop dieting. Intemational Hownt of Eating Disonders, 11, 261-268.

Polvy, J., \& Herman, C. P. (19931. Etology of binge eating: Psychological mechanisms, In C. G. Farbum IEd.), (1993). Binge exing. Nature, assessment, and treatment lpp. 173-205]. New Yonk, NX: Guilord Press.

Porzelius, L. K., Houston, C., Smith, M., Ariken, C., \& Fisher, E. (1995). Comparison of a standard behavioral weight loss treatment and a binge eating weight loss treatment. Behawor Therapy $20,119.134$.

Presnell, K., \& Stice, E. [2003]. An experimental test of the effect of weight los disting on bultimic pathology: Tipping the scales in a different direction. Jounal of Abnomal Psychology $112,166-170$.

Pritchard, D. A. Hwhdman, J., Baba, F. (1099). Nutritional counselling in general practice: a cost effective analysis. Jounat of Epdemiology and Commurity Health, $53,311-0$.

Quinn, D. M. \& Crocke, J. (1999). When ideology hurts: Effects of belief in the Protestant ethic and feeling overweight on the psychologica! well being of women. Joumal of Personalty and Sochal Psycholow, 77 , $402 \cdot 414$.

Richter, P, Wemer, I., Heerlein, A., Kraus, A., \&aver, H. (1998). On the walidity of the Beck Depression Inventory: A review. Psychopathology 31, 160.168.

Rissanen, A., Hakala, P., Lissner, L., Matular, C. E, Koskenwo, M., \& Rönnema, T. 120021 . Acquired preference especially for dietary fat and obesity: a study of weight-discordant monozychotic win pals. Imemationat Journal of obesity, 26,973.977.

Roberts, R. E., Deleger, S., Strawbridge, W. J., \& Kaplan, G. A. (2003). Prospective association between obesity and depression: Evidence from the Alaneda County Study. Intemational Jourrat of Obesity, 27, 514.521.

Robinson, T. N. (1999). Behavioural treatment of childhood and adolescent obesity. Intemational Journat of Opesity, $23,55257$.

Roets, A. \& Jansen. A. (2002). Implicit and explicit attitudes toward hightat foods in obesity. Joumal of Abnomal Pychology, 111,517-521.

Roefs, A., Ouaedackers, L., Werti, M. Q. Wolters, G. Havermans, R., Nedethoom, C., et al lin pressi. The enviroment determines whether hightat foods are associated with palatable or with unhealthy. Behtavour Research and Therap

Rogers, E. M. (1983). Diffision of movations (3rd ed.). New York: Free Press.

Rosenberg, M. (1905). Socety and the adolescont self mage. Princelon, N: Princeton Iniversity Press. Rosenberg, M. 11979j. Concerwing the self. New York, NY: Basis Books, Inc, Publishers.

Rosmond, R. 2004). Obesify and depression: same disease, different names? Medlcal Hypotheses, $02,970.070$. Ruderman, A. ]. (1986). Dietary restrant: A theoreucal and empirical review. Psychological Butetip, 00,247262. Saris, W. H. 20011. Verylow-calone diets and sustained weight loss. Oberity Research, $0,295 \mathrm{~s} \cdot 30 \mathrm{Ls}$.

Sarwer, D. B. Wadden, T. A., \& Fabricatore, A. N. 120051. Psychosocial and behavioral aspects of bariatric surgery. Obesity Research, 13, 639-648. 


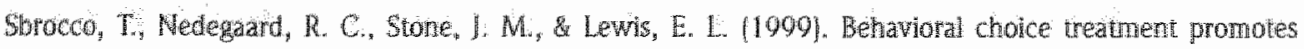
coninuming weight loss; prelininary results of a cognitive-behavioral decision-based treatment for obesity. Wunal of Consulting and Chincal Psychology, $07,260260$.

Seidell, J. C. \& Hegall, K.M. (1907). Assessing obesity: classification and epidemialagy. British Medical Bulletin, 53,238252 .

Sherwood, N. E. Jeffery, R. W. 䍃 Wing, R. R. (1909). Binge status as a predictor of weight loss treatment

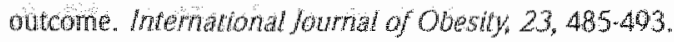

Siostrom; L. Lindroos, A. K., Peltonen, M. Torgerson, J., Bouchard, C., Carlsson, B., et al. [2004]. Lifestyle, diabetes, and cardiovascular risk factors 10 years after bariatic surgery. New England Jownal of Medicne, $397,2683-2093$.

Smith, D. E. Marcus, M. D., \& Kaye, W. [1992]. Cognitwe behavional treatment of obese binge eaters. Jhternational Joumal of Eating Disorders, $2,257.262$.

Sparks, R. Conner, M. James, R. Shepherd, R. \& Pavey, R. (2001). Ambivalence about health-related behavlaurs: An exploration in the domain of food choice. British foumal of Heallh Psychology, 6, 53-68.

Spitzer, R. L., Devin, M., Walsh, B. T., Hasin, D., Wing, R, Marcus, M., et al (1002). Binge eating disorder: a multisite field wial for the diagnostic criteria. Intemational Joumat of Eating Disorders, 1/. 191-203.

Staflet, A., Graal, C. de, Staveren, W. A. van, \& Jong, A. A. J. G. de [1994). Attitudes towards hightat loods and their low at alternatives: Reliablity and relationship with fat intake. Appetite, 22, $183-196$.

Stice, E. (2002). Risk and maintenance factors for eating pathology: A meta-analytic review. Psychological Bullezin, 128, 825.848 .

Stice, E. Cameton, R. P., Killen, I. D., Hawward, C., \&aylor, C. B. I1 1099]. Naturalistic weight reduction efforts prospectively predict growth in relative weight and onset of obesity among female adolescents. Jourpal of Consulting and Chinical Psychology, 07, 967-974.

Striegel Moore, R. H., Wilson, G. T. Willey, D. E., Elder, K. A., \& Brownell, K. D. [1998). Binge eating in an obese community sample. International Joum af of Eating Disorders, $23,27-37$.

Stunkard, A. I., Fairh, M. S. Allison, K. C. (2003). Depression and obesity. Biological Psychiaty. 54, 330-337.

Stunkard, A. I, Wadden, T. A. (1902). Psychological aspecis of severe obesity. The Americar journat of Chinical Nutrition, $55,524 s, 5325$.

Sullwam, K. A. 2001). The climical leatures of binge eating disorder and bulimia nervosa: What are the differences? Camadian Joumal of Counselling $35,315-328$.

Tanco, S. Linden, W, \& Eanle, T. (1998). Well-being and morbid obesity in women: A controlled therapy evaluation. International younal of frating Disorders, $23,325.339$.

Telch, C. F, \& Agras. W. S. (1094). Obesty, binge eating and psychopathology: Are they related? International Jownal of Lating Disonters, $15.53-61$.

Telch, C. F., Agras, W. S. Rossiter, E. M., Wilfey, D., Kenardy, ) (1990). Group cognitive-behavioral treatment for the nonpurgng bulimic: An initial evaluation, foumal of Consulting and Clinical Psychology, 58,029035 .

Torgerson, J. S. Agren, L., S Sigstrom. L. (1909). Effects on body weight of strict or liberal adherence to an witial period of VLCD treatment. A randomised, oneyear clinical trial of obese subjects. International Journal of Obesity, $23.100-197$ 
Torgerson, J. S. Lissner, L, Lindroos, A. K., Kruije, H, \& Slostron, L I 007 . VICD plus dietary and behavioural support versus support alone in the treatment of severe obesty. A randomised two year dintal trial. Intenatonal fowmal of obesity, $21,987.94$.

Troisi, A., Scucchi, S., San Martino, L. Montera, P, d"Amore, A., \& Moles, A. 2001, Age specificly of the

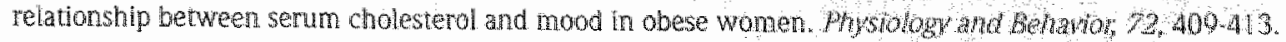

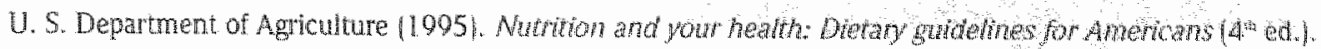
Washington, DC: Department of Agriculture Home and Garden Bulleth.

Van den Borne, H. W. Geertsma, F, Westmaas Jes, M. M. (1988). Effecten van een niewwe groepsbehandelng voor dikke vrouwen. / Effectiveness of a new group treatment for obese women. Cediag and Gezontheid: Thdschith wor Pychologte en Gezondheit, 10.108 .116$.

Venditti, E. M., Wing, R. R., Jakick, J. M., Butler, B. A. \& Marcus, M. D. (1096). Welght cycling psychological health, and binge eating in obese women. Jounat of Consulting and Cintcal Psychology, 04, 400405.

Visscher, T. L., Kromhout, D., \& Seidell, J. C. (2002). Longterm and recent time trends in the prevalence of obesity among Dutch men and women. Intemational Joumal of Obesto, $26,1218-1224$.

Visscher, T. L., \& Seidell, I. C. (2001). The public health impact of obesity. Annual Review of Public Heath, 22 , $355 \cdot 375$.

Wadden, T. A., Brownell, K. D., \& Foster, G. D. (2002). Obesity: Responding to the global epidemic. Doumal of Consuting and Cinical Pychology,70.510-525.

Wadden, T. A., Sawer, D. B., \& Berkowitz, R. I. (1999]. Behavioural treatment of the overweight pattent. Bailteves Best Practice \& Researh in Chinical Endocrinology \& Metabolism, 13. $93-107$.

Wardle, I. \& Solonons, W. (1994). Naughty but nice: A laboratory study of health information and food preferences in a community sample. Health Psychology, $13,180.183$.

Wardle, 1., Waller, 1. \& Rapoport, L. (2001). Body dissatisfaction and binge eating in obese women: the role of restraint and depression. Obesiy Resewch. 0,778.787.

Wilfey, D. E., Agras, W. S., Teich, C. F, Rossite, E. M. Schneider, J. A., Golomb Cole, A., et al. [1093). Group Cognitive wehavioral therapy and group inerpersonal psychotherapy for the nonpuiging bulimic individual:

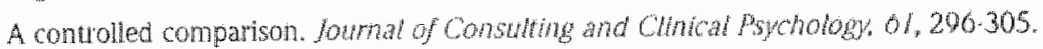

Wilhey, D. E., Schwartz, M. B., Spurrell, E. B., \& Fairburn, C. G. 119971. Assessing the specific psychopathology of binge cating disorder patients: interwiew or selleport? Behawou Resench and Therawy, $35,1151.1159$.

Winly, D. E., Schwartz, M. B., Spurrell, E. B., Fairdum, C. C. 12000 . Using the Eatng Disorder Lxamination to identiry the specific psychopathology of binge eating disorder. Intemational /ournal of Camis Disonders, $27.259 \cdot 269$

Wison, G. T. $(1994)$. Behavioral treatment of obesity: Thirty years and counting. Advances in Jehaviour Research and herapy, 10, 31-75.

Wilson, G. T. 11099$\}$. Cognitive behavior therapy for eating disorders: Progress and problems behathou Reseakh and Wherap, 37, 579-595.

Wilson, G. T, Faitburn, C. C., Agras, W. Wals, B. \& Kramer, H. 20021. Cogntive behavioral therapy for

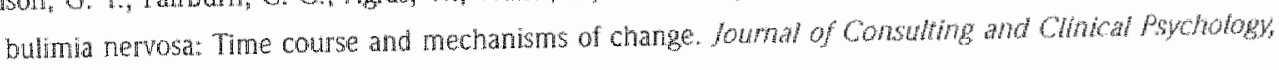
$70.267-274$ 
Wison, G. T, \& Smith, D. (1987). Cognituebehavional treatment of butimia nervosa. Annals of Behavorat Medicine, 9,1217 .

World Health Organization (1908). Oberity prevering and managing the global epidemic. Geneva, Zowitzetland: World Heath Organzation.

Wotd Healtit Organiation 2000 . Obesity preventing and managh the global eptdentic. WHO Obesity Techical Report Series 894 . Geneva; Zwtzetand: World Health Organization.

Zack, M. Tonealto, T., \& Macleod, C.M. (1999). Implicit acivation of alcohol concepts by negaive affecive cues distinguishes between problem drinkers with high and low psychiatric distress. Journat of Abnomal Pychology, 108, $518-531$. 
Reforences 


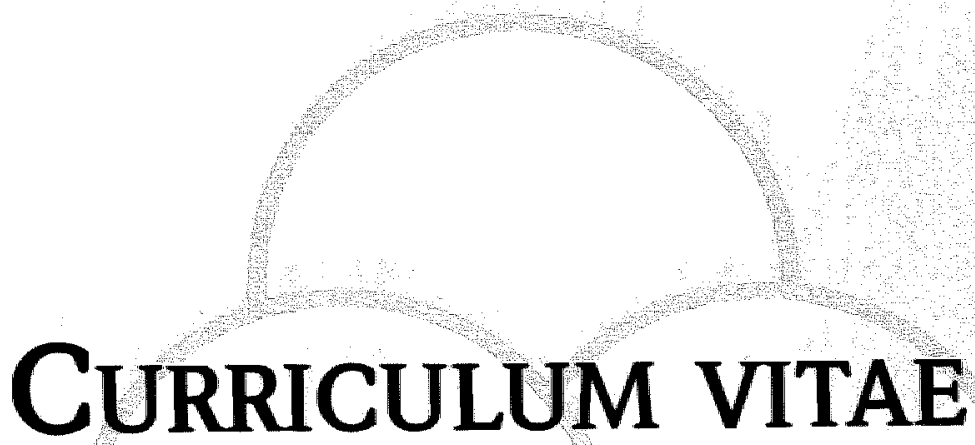

Publications 
Marieke Werril was born on April 11, 1975, in Nijmegen, the Netherlands. In July 1903 she graduated from secondary school (WWO; Het Wagenings Lyceum in Wageningen), In September of that year, she started studying health sciences at Maastricht University. Six years later August 1999) she received her master's degree in both movement sciences and public health. In September 1999, she began her PhD project at the Faculty of Psychology at Maastricht University. Since September 2005, she is a research fellow at the Faculty of Psychology at Maastricht University. 
Werri, M. O., Mukens, S. Hospers, H., Jansen, A. (2005). Dieday treament for obesty wewdeds BW and mproves eating poychopacholoks, selfesteen and mood Manuscript submitted for publication.

Werri, M. Q. Mukens, S., Hospers, H., Jansen, A. lin press/. Overweight and obesity the signiffance of a depressed mood. Patient Equation and Comselmg.

Werri, M. O, Mulkens, S., Elgersma, H., Ament, A., Hospers, H. I, Bansen, A. (2005). CBT prevents relapse

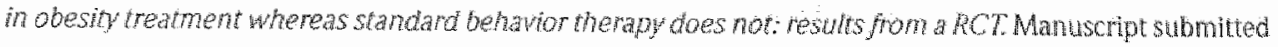
for publication

Werrij, M. Q., Roefs, A. Ilansien, I., Stapert, D. Wolters, G., Mulkens, S., Hospers, H. J. \& Jansen, A. [2005\}. Early associations with palatable foods in obesity are not disinhibition related but restraint retated. Manuscript subnitted for publication

Werrij, M., Ruiter, R., \& Kok, G. (2000). Het gebruik wan angst in gezondheidswoontichting: effecten van angstaanjagende informatie op gevaarcontrole processen, angstcontrole processen en informatiebehoefte. In: Wit, J. de, Aarts, H., Vermunt. R., Ybema, JI. [red.). Socide psychologie en har toepassingen. Dellt: Eburon.

Werri, M. Voeten, C. D., Adriaanse, H. P., \& Thorburn, M. I. 20001. Fomal handing routines in Janaican imfants; knowledge, attudes and behaviour. West Indian Medical foumal, 49, 3842.

Adam, 1. J., Nieuwenstein, I. H., Huys, R., Pas, F. G. W. C.. Kingma, H., Willems P., \& Werry, M. 2000]. Control of rapid aimed hand movements: The one-target advantage. Joumal of Expermental Psychology: Human Perceprion and Performance, 20,295.312.

Mukens, S. \& Werti, M. 120021 . You can't always ger what you want: Workshop over CBT bij obesitas, EABCT 2002, Maastricht. De Bycholoog, $37,682083$.

Roefs, A., Quaedackers, L., Werri, M. Q., Wolters, G., Havermans, R., Nederkoom, C., Van Breikelen, G. \& Jansen, A. in press. The enviromment infuences whether high fat foods are associated with pallatable or with unfealthy. Behavour Research and Therapy

Roefs, A., Werri, M. Q., Smulders, F. T. Y, \& Jansen, A. (in press). The value of indirert measures for assesing food preferences in abnormat eating. Jounat of Consumer Frotection and lood Safety.

Ruiler, R. A. C. Werplanken, B., Kok, G., \& Werri, M. Q. (2003). The role of coping appratsal in reactions to fear appeals: Do we need threat intormation? Joumal of Heath Psychology, $8,465.474$. 
